\title{
Icings near the Tibbitt to Contwoyto Winter Road, Great Slave Uplands, Northwest Territories
}

\author{
by
}

Wendy Elizabeth Sladen, B.A., B.A.Sc.

A thesis submitted to the Faculty of Graduate and Postdoctoral Affairs in partial fulfillment of the requirements for the degree of

Master of Science

in

Geography

Carleton University

Ottawa, Ontario

C 2017, Wendy Elizabeth Sladen 


\begin{abstract}
Icings were investigated near the Tibbitt to Contwoyto Winter Road (TCWR) to examine the relation of overflow timing to air and ground temperature, rainfall, snow accumulation, and the winter road. Icings developed before the end of freezeback by intermittent overflow of water from upstream lakes. Open-system freezing in saturated peat caused build-up of hydraulic pressure, leading to overflow. The active layer remained hydrologically active after the overflow period but hydraulic pressures, possibly related to the upstream lake, were insufficient to cause further icings. The duration of the overflow period and spatial extent were positively related to autumn rainfall. In addition, above average early winter air temperature and average early winter snowfall were important factors contributing to overflows at several portages noted in the TCWR maintenance records. Development of icings in the Canadian Shield thresholdmediated hydrological regime is dependent on basin catchment area and antecedent conditions.
\end{abstract}




\section{Acknowledgements}

This thesis could not have been accomplished without the support of a myriad of individuals. First my supervisor, Chris Burn, for meeting with me regularly, keeping me on track, and helping me see that I have something to say. Meetings that never felt timeconstrained and often included a cup of tea and a couple of chocolate-covered digestives were deeply appreciated.

My colleagues at the Geological Survey of Canada (GSC) were instrumental. My colleague and committee member, Stephen Wolfe, supported this endeavour from its earliest beginnings right through to the end. His enthusiasm for the topic and questions to make me think kept this project alive. My immediate colleagues (in alphabetical order), Olivier Bellehumeur-Génier, Nicole Couture, Réjean Couture, Caroline Duchesne, Mark Ednie, Anne-Marie LeBlanc, Peter Morse, and Sharon Smith, provided ongoing encouragement and didn't ask much of me in return. Peter and Stephen were instrumental in the field and collected data for me while I was on parental leave.

Clint Ambrose, Nahum Lee, and Marty Sanderson of Indigenous and Northern Affairs provided field assistance and background from years of experience inspecting the Tibbitt to Contwoyto Winter Road (TCWR). Shawne Kokelj of Northwest Territories Water Resources supplied the snow sampler to measure snow depths and densities. Steve Kokelj of Northwest Territories Geological Survey provided several cameras and helpful insights into subarctic Canadian Shield hydrology during the freezing season.

Ron Near of Diavik Diamond Mines Inc., Tim Tatrie of Nuna Logistics Ltd., Art Blum and Kirk Keller of Dome Lake Camp contributed reports, TCWR experience, 
historical accounts of overflow along the TCWR, and enabled our accommodation at Dome Lake Camp, all of which was extremely helpful. Rick Hoos of EBA Engineering Consultants Ltd. shared helpful shapefiles and reports on the study portages.

Financial support for this thesis was provided by Natural Resources Canada through the Climate Change Geoscience Program. The GSC provided additional financial and time support, which was instrumental for completing this thesis.

Lastly, and most importantly, my friends and family have been there supporting and putting up with me through this last push. I could not have seen this through without the love and endless support of my Wren and Gabe, Mom and Dad, Lenny and Arleen, Jill and Richard, Emma and Max, and encouragement and support from my friends including Heidi Chestnut, Allison Hewlitt, and Melissa Marschke. 


\section{Table of Contents}

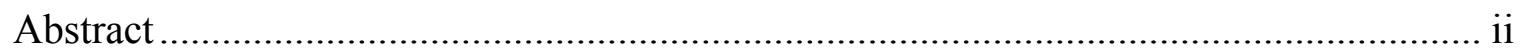

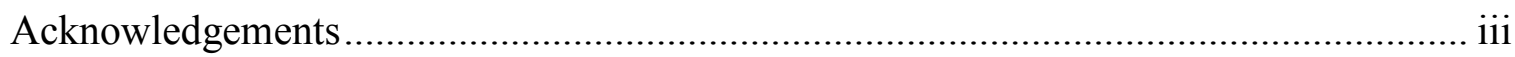

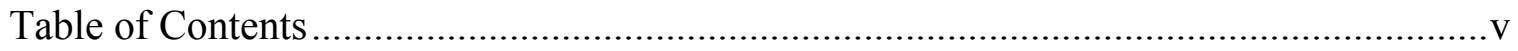

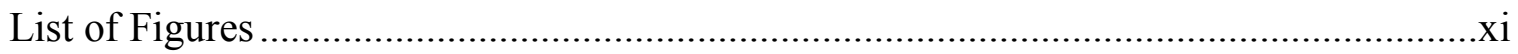

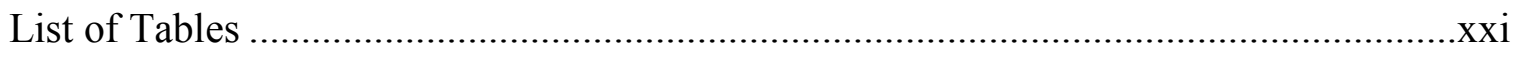

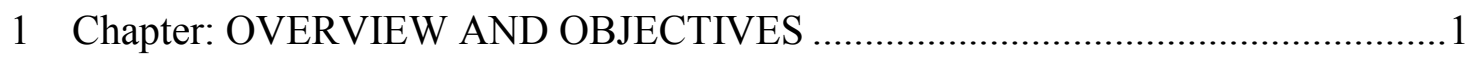

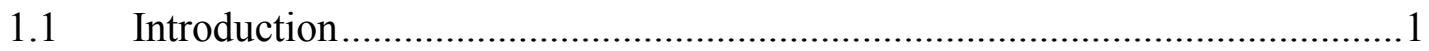

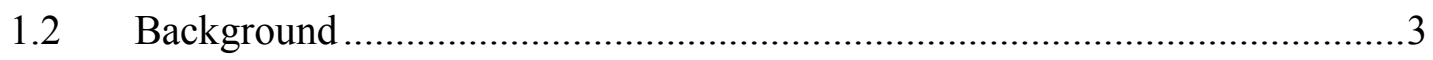

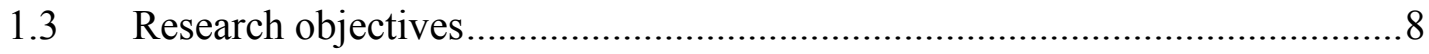

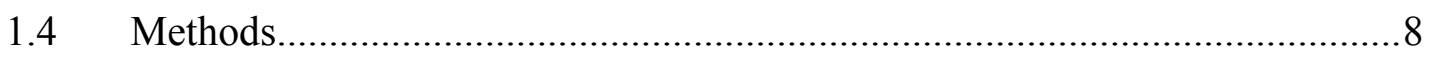

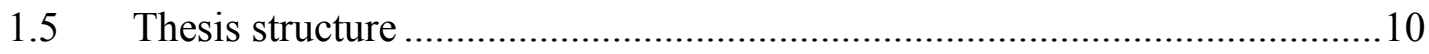

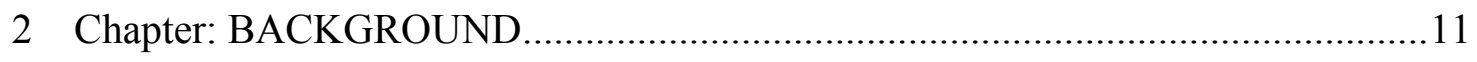

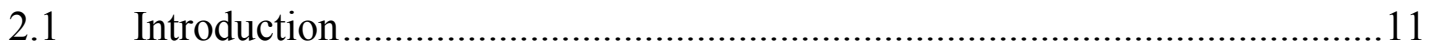

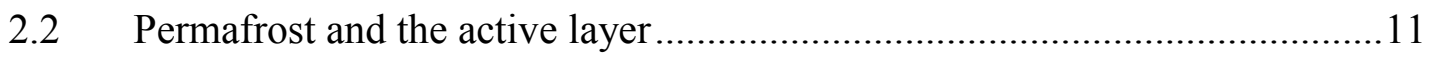

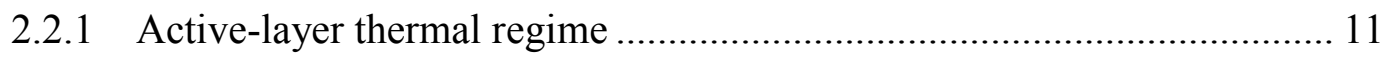

2.2.2 Thermal properties of the ground ..................................................... 15

2.3 Active-layer freezeback ........................................................................ 17

2.4 Controls on active-layer freezeback .......................................................18

2.4.1 Air and ground surface temperature ……........................................... 18

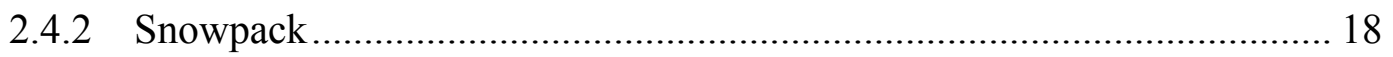

2.4.3 Moisture content, unfrozen water, and soil texture.................................. 19 


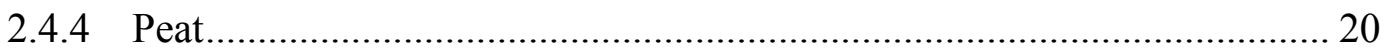

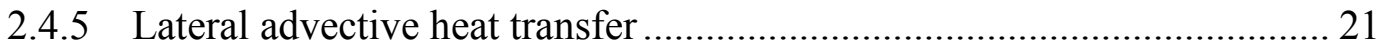

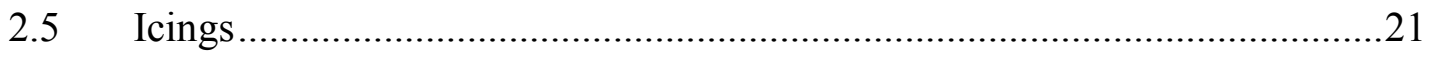

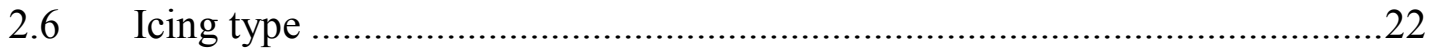

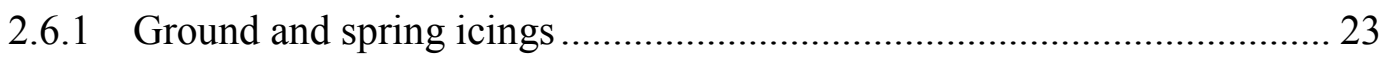

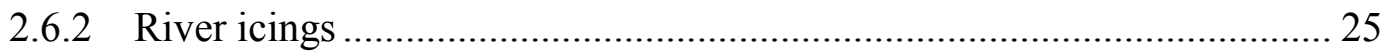

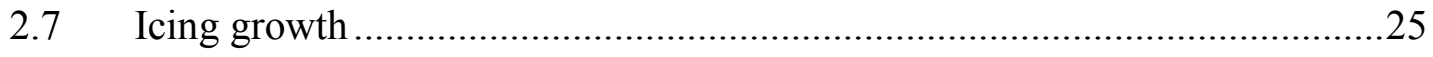

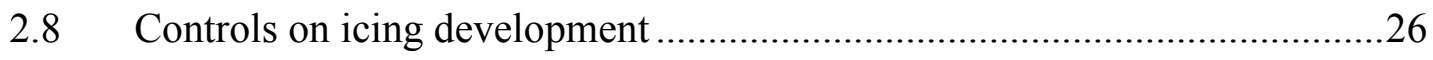

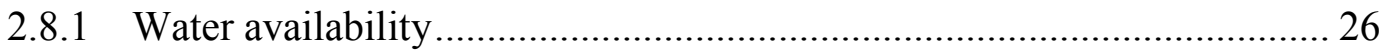

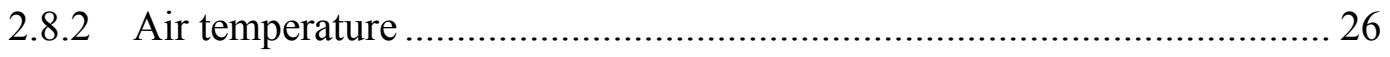

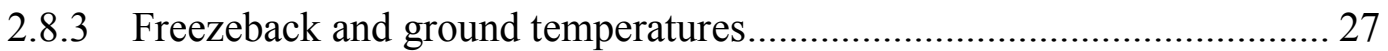

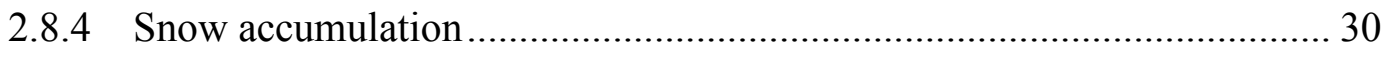

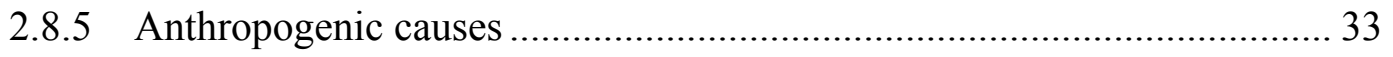

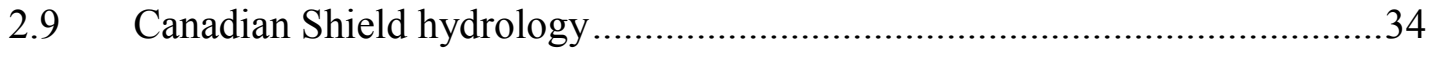

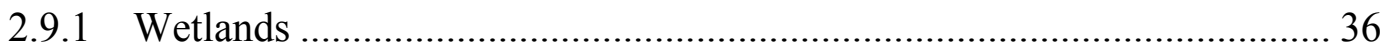

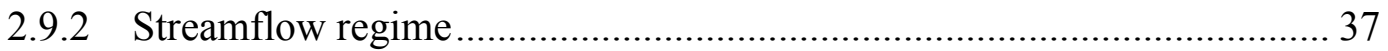

2.10 Tibbitt to Contwoyto Winter Road ..............................................................

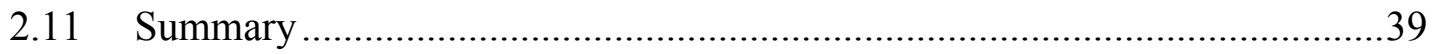

3 Chapter: STUDY AREA AND METHODOLOGY …………………....................40

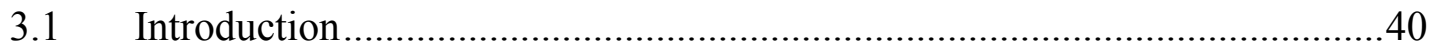

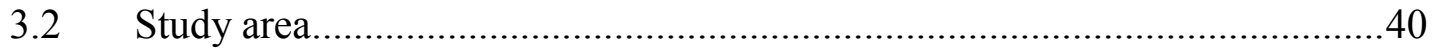

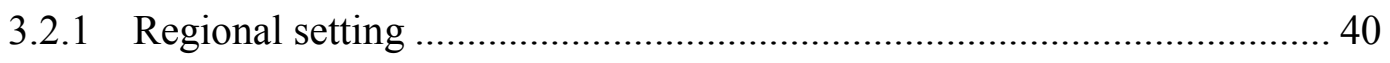

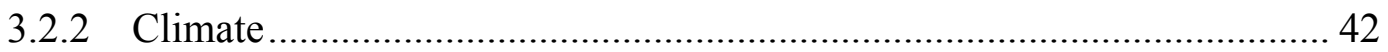




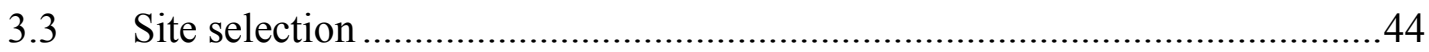

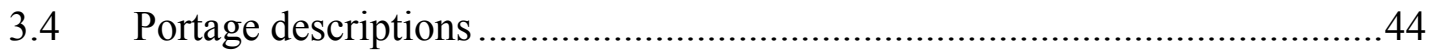

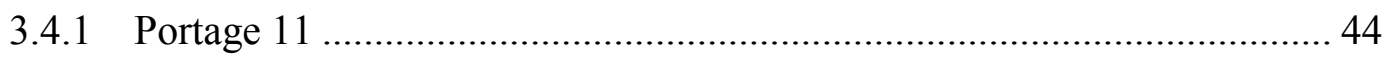

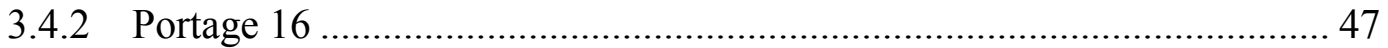

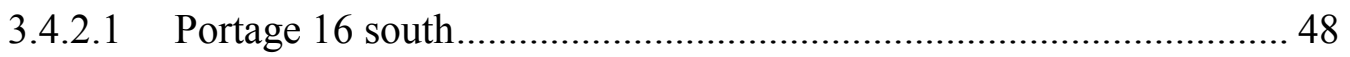

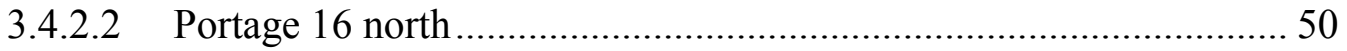

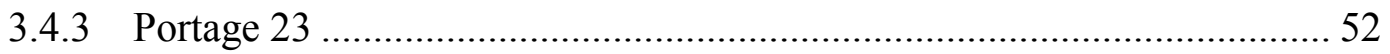

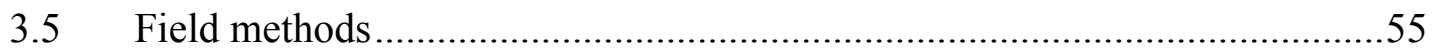

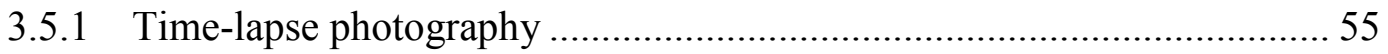

3.5.2 Air and near-surface ground temperature ………………….................. 57

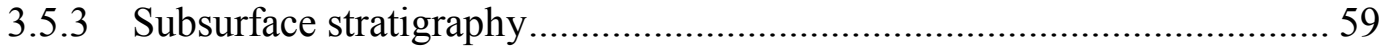

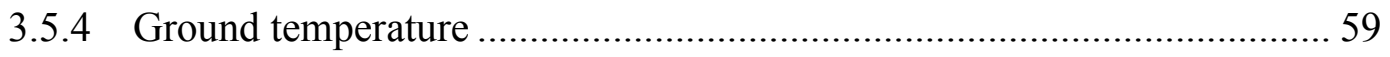

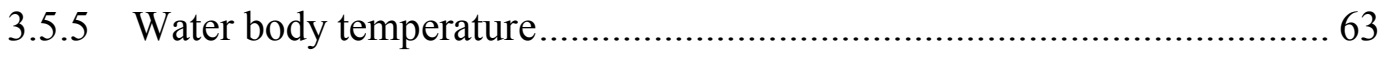

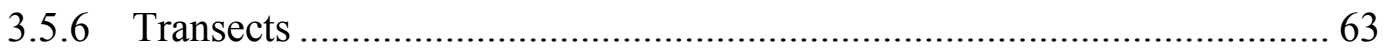

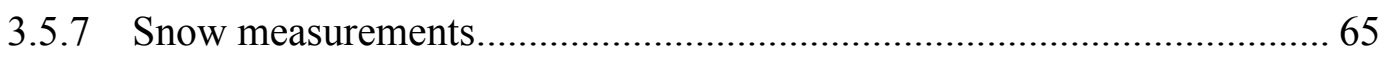

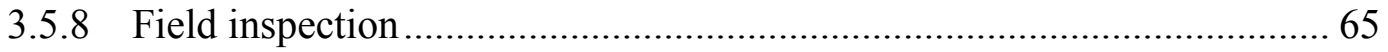

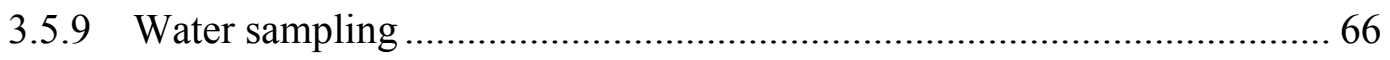

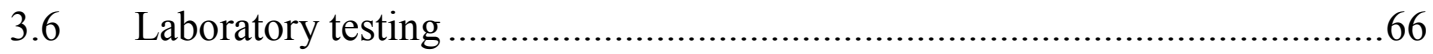

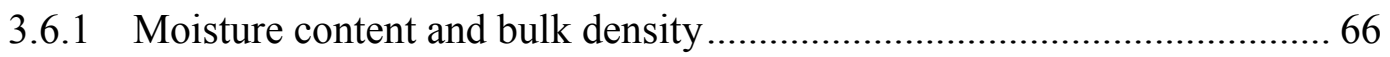

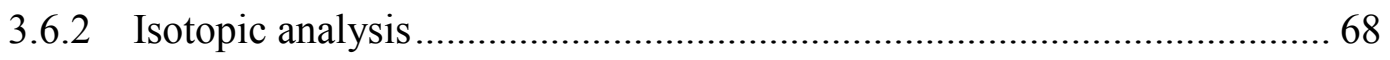

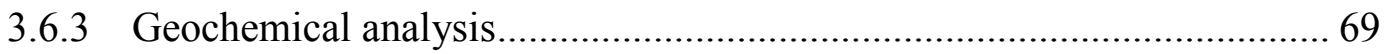

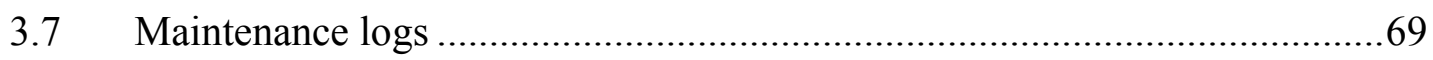

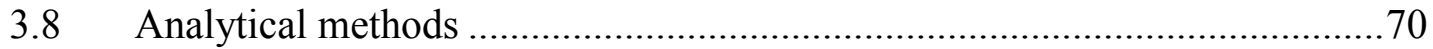




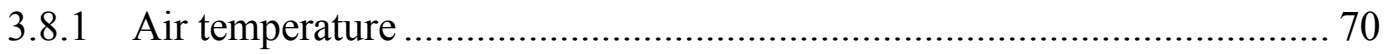

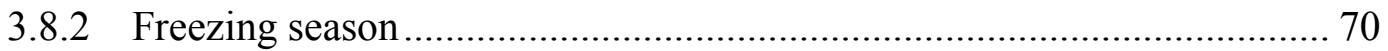

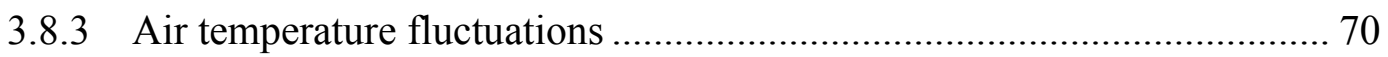

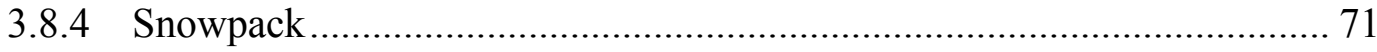

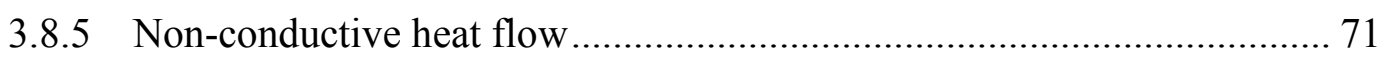

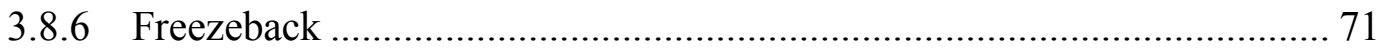

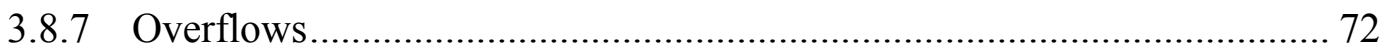

3.9 Modelling frost penetration......................................................................

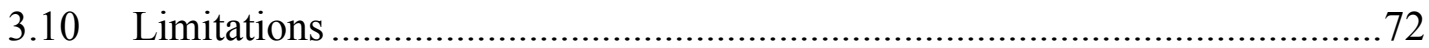

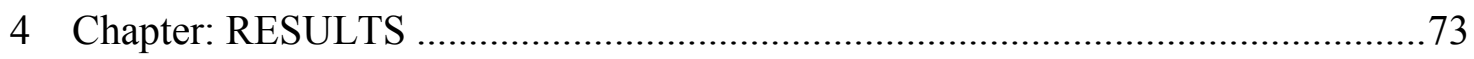

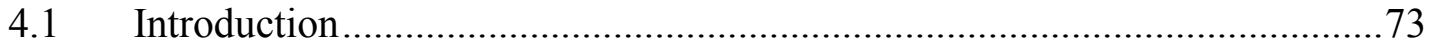

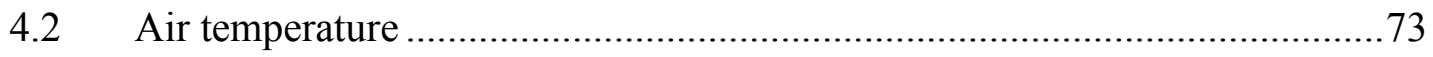

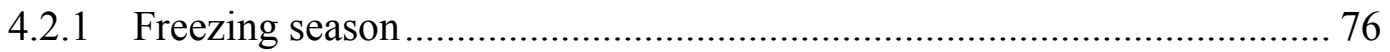

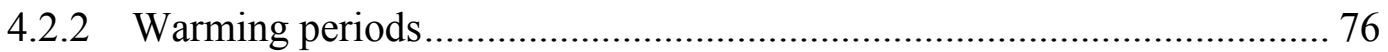

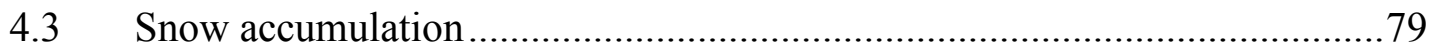

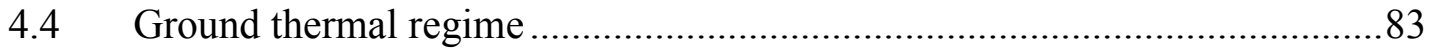

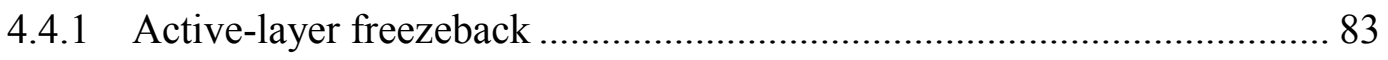

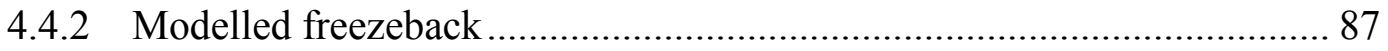

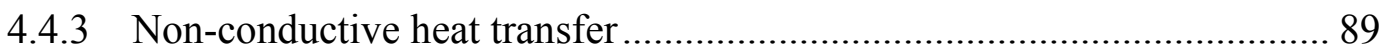

4.4.4 Thermal regime and freezeback of water bodies .................................... 89

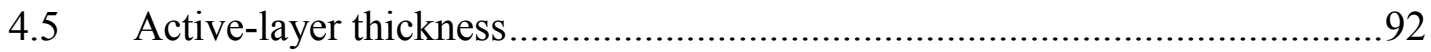

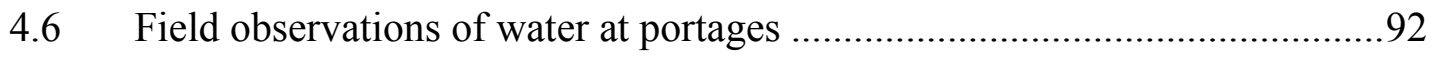

4.7 Moisture contents and bulk density ............................................................95 


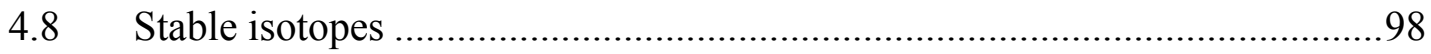

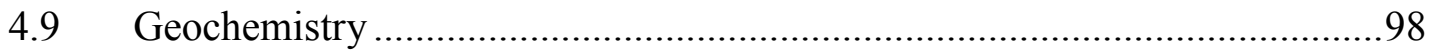

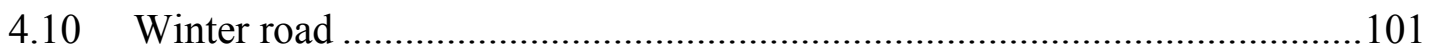

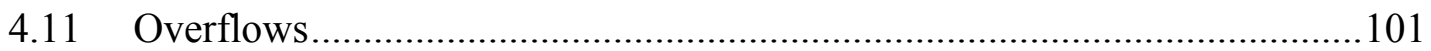

4.11.1 Overflows and air and near-surface temperature fluctuations ............ 105

4.11.2 Overflows and snowpack development .......................................... 105

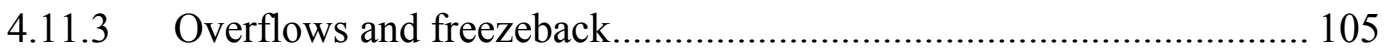

4.11.4 Overflows and modelled freezeback.............................................. 108

4.11.5 Overflows and ground thermal regime ……................................... 108

4.11.6 Overflows and source water........................................................... 110

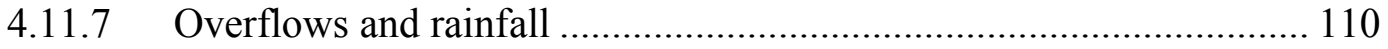

4.11.8 Overflows and Tibbitt to Contwoyto Winter Road............................. 112

4.12 Historical overflows .............................................................................112

4.12.1 Historical overflows and air temperature fluctuations........................ 112

4.12.2 Historical overflows and seasonal meteorological variables .............. 114

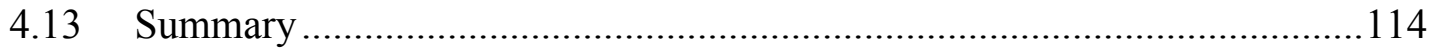

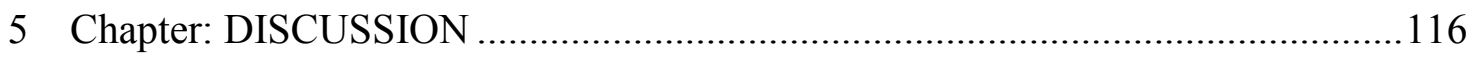

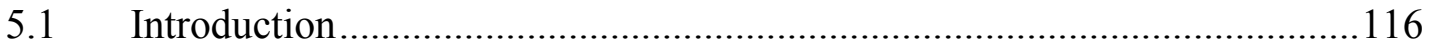

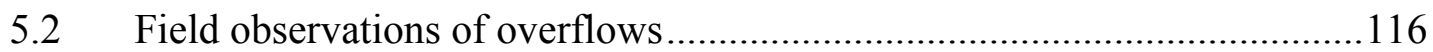

5.3 Historical TCWR overflow observations.................................................118

$5.4 \quad$ Research hypotheses revisited .............................................................

5.5 Factors controlling overflows along the TCWR …………………….........120

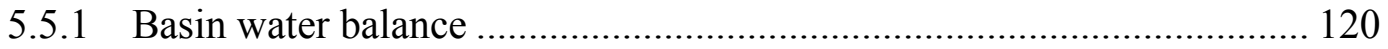




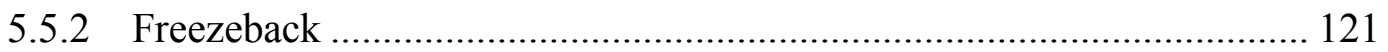

5.5.3 Air temperature fluctuations ....................................................... 122

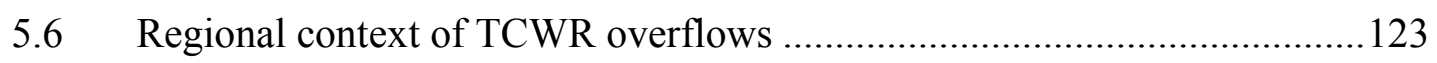

5.7 Climatic context of TCWR overflows ............................................... 125

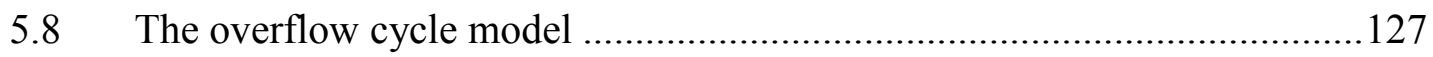

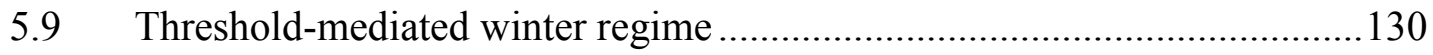

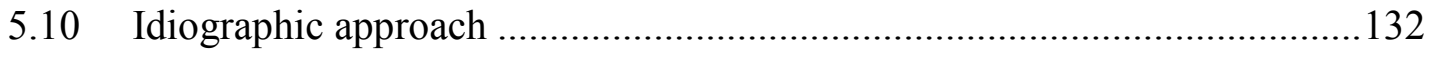

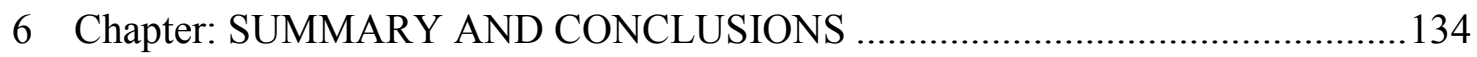

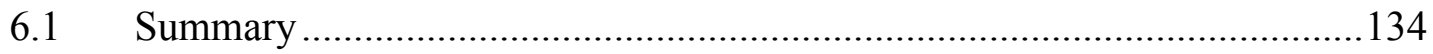

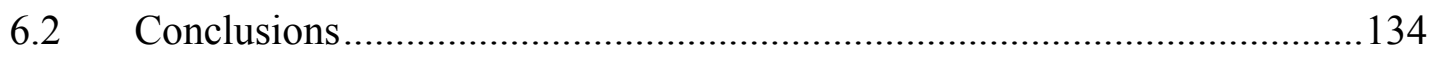

6.3 Research implications and future work .................................................. 135

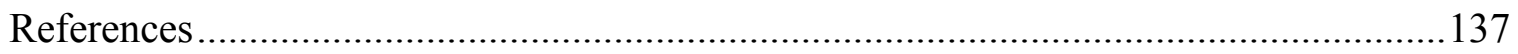




\section{List of Figures}

Figure 1.1 Ecoregions in the Great Slave Uplands and the Tibbitt to Contwoyto Winter Road (adapted from Ecosystem Classification Group 2008, 2012). Study portages

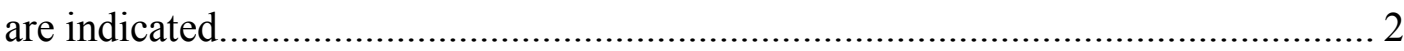

Figure 1.2 Icing on the Mackenzie Valley winter road south of Tulita in February 2006.

Photo by W. Sladen.

Figure 1.3 Occurrence of groundwater in permafrost: suprapermafrost, intrapermafrost, and subpermafrost (after Woo 2012, Fig. 3.1, p. 74).

Figure 2.1 Schematic ground temperature profile describing the thermal regime of permafrost terrain. $T_{\text {mean }}, T_{\min }$, and $T_{\max }$ are respectively the mean, minimum, and maximum ground temperatures at depth. $\mathrm{T}_{\mathrm{TOP}}$ is the temperature at the top of permafrost (after Burn 2004, Fig. 3.3.2, p. 393).

Figure 2.2 Daily mean ground temperatures at site P16N (P16N-ROW) for September 2013 to 2014. Readings are shown every four days for clarity. The thermal seasons of the active layer: snowmelt (SM), thaw season (TS), freezeback season (FB), and the frozen season (FS) are shown, as well as progression of the freezing front. The $120 \mathrm{~cm}$ depth sensor is in permafrost.

Figure 2.3 Schematic of ground or spring icing formation depicting the ground thermal and hydrological conditions in the (a) thaw season and (b) early part of the freezeback season (after van Everdingen 1982b, Fig. 18, p. 260).

Figure 2.4 Time series of (a) icing area, (b) autumn rainfall and winter yield, and (c) warming periods for Baker Creek near Yellowknife, NT, from 1984/85 to 2011/12. For the years with data, icings were only observed when there was baseflow and the 
frequency of winter warming periods was greater than 25 (after Morse and Wolfe 2017, Fig. 3) 28

Figure 2.5 Time series showing (a) air temperature and snow, and (b) hydrostatic water level for December 9, 1981 to January 2, 1982. Plots show rising water level (December 15-16 and 22-23) coinciding with subfreezing warming periods following cooling periods (after Price and FitzGibbon 1987, Fig. 4, p. 2078) 29

Figure 2.6 Time series plot showing hydrostatic head, frost penetration, and level of the icing surface from November 1971 to October 1972 (after Kane et al. 1973, Fig. 2,

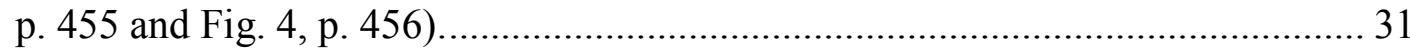

Figure 2.7 Seasonal frost and hydrostatic water level for peat in (a) bog and (b) fen in non-permafrost. Groundwater flow throughout winter maintains a high hydrostatic water level in the fen resulting in overflows and icing development (after Price and FitzGibbon 1987, Fig. 3, p. 2078). 32

Figure 2.8 (a) Schematic showing a chain of lakes within a drainage basin, lake catchment variability, and direction of basin outflow. (b) Threshold-mediated flow concept for a series of three lakes (i.e., 1, 2, and 3 in (a)) showing the intermittent flow connectivity as function of lake water inputs and outputs, antecedent storage, and net storage gain or loss over time for individual lakes. Between $t_{0}$ and $t_{1}$, all lakes have a positive water balance but only the water level in lake 2 exceeds the threshold and generates outflow. Between $t_{1}$ and $t_{2}$, the positive water balance in lakes 1 and 3 generates outflow whereas the negative water balance in lake 2 lowers the level below the threshold and outflow ceases, interrupting the continuity of flow (modified from Woo 2012, Fig. 7.38, p. 338). 35 
Figure 3.1 Mean monthly air temperature and total monthly precipitation, divided between rainfall and snowfall (in snow water equivalent), for 1981-2010 at Yellowknife Airport (Environment Canada 2016). 43

Figure 3.2 (a) Aerial view of P11 showing location of instrumentation and distribution of land cover type. Blue arrows indicate direction of water flow. (b) Cross-section of A-A' at P11 monitoring site. The bedrock (BR) and frost table (FT) were determined by probing and hand augering in September 2012. Photo taken by W. Sladen, September 2012. 46

Figure 3.3 (a) Aerial view of P16S showing location of instrumentation and distribution of land cover type. The area was burned by a wild fire in 1998. The bog in the bottom portion of the image slopes very gently towards Lake P16-1. (b) Crosssection of A-A' at P16S monitoring site. The frost table (FT) was determined by probing and hand augering in September 2012. Photo taken by W. Sladen, September 2012 .

Figure 3.4 (a) Aerial view of P16N showing location of instrumentation and distribution of land cover type. Blue arrows indicate direction of water flow. The area was recovering from a 1998 wild fire. (b) Cross-section of A-A' at P16N monitoring site. The frost table (FT) is shown for September 2012 and 2013. Photo taken by W. Sladen, September 2013. 51

Figure 3.5 (a) Aerial view of P23 showing location of instrumentation and distribution of land cover type. Blue arrows indicate direction of water flow. The blue oval marks location of overflow observed during the study period. (b) Cross-section A-A'at P23 monitoring site and (c) cross-section B-B', north of A-A'. The depth to 
bedrock (BR) and frost table (FT) were determined by probing and hand augering in September 2012 (b) and 2013 (c). Photo taken by W. Sladen, September 2013.

Figure 3.6 Instrumentation at P23. Image taken looking west across the winter road ROW. Vertical thermistor strings are located on ROW at P23-ROW and off ROW at P23-OFF and P23-OFF2 (located off image left behind the birch shrub). The four pink flags represent the location of each sensor $(30 \mathrm{~cm}$ depth $)$ in the horizontal transect (P23-TRA). The air temperature sensor is located in the radiation shield and the ground surface temperature sensor is $2 \mathrm{~cm}$ beneath the ground surface at the base of the air temperature pole (P23-AG). The inset shows the wildlife camera used for the time-lapse photography. Photos taken by W. Sladen, September 2012.

Figure 3.7 (a) Hand augering with the peat auger at portage 16 north (P16N). (b) An example of the ice-rich return on the peat auger. Photos by W. Sladen, September 2012. 60

Figure 3.8 (a) Placement of sensors directly into the soil at portage 11 (P11-ROW). (b) In some cases sensors were attached to a stick (b) or a wooden dowel and then installed in a borehole. This setup is the vertical thermistor string that was installed at portage 16 north (P16N-ROW). Photos by W. Sladen, September 2012 ........... 62

Figure 3.9 (a) View towards the northwest along the frost depth probing transect at portage P23 (September 2013). (b) Measuring snow depth and density using the Geoscientific Metric Snow Sampler at portage 23 (February 2014). Photos by W. Sladen. 
Figure 3.10 (a) CRREL core showing icing ice (left) on top of frozen peat (right) at portage P23. (b) Using an ice auger on Lake P23 to obtain a lake water sample. Photos by W. Sladen, February 2014.

Figure 4.1 Daily mean air temperatures at P16S from September 2012 to September 2014. The periods of observed overflows are shaded in grey.

Figure 4.2 Snowpack development at P11, P16N, and P23 for 2012/13 (above) and at P16N and P23 for 2013/14 (below) as observed from the time-lapse photography. The snow depth reported at Yellowknife Airport (YZF) is also included (Environment Canada 2016). The light grey shaded areas represent the period of observed overflows at P23; the dark grey shaded areas represent observed overflow events. 80

Figure 4.3 Snow depth (a) and density (b) measured at the study sites in February 2013 and 2014. Box and whisker plots present median, minimum, maximum, lower quartile, and upper quartile values of $\mathrm{n}$ measurements.

Figure 4.4 Daily mean temperatures at 15, 30, 60, and $120 \mathrm{~cm}$ depth off and on ROW at sites (a, b) P16S and (c, d) P23 from September 2012 to June 2014. The black arrows mark the first snow clearing and the grey arrows mark the first flooding of the ROW. No winter road construction information was available at P16S in $2013 / 14$

Figure 4.5 (a) Daily mean air temperature and (b) surface temperature at P23 from October 1, 2012 to Feb 28, 2013. (c) Modelled frost penetration with time, modelled incremental daily freezeback, and measured frost penetration at P23-OFF 
and P23-ROW. Average measured frost penetration is represented by the dashed grey line. Observed overflows are shaded in grey. 88

Figure 4.6 Six-hour ground temperature change $(\mathrm{dT})$ at $15 \mathrm{~cm}$ depth off and on ROW at P16S and P23 for 2012/13. Overflows (O), TCWR snow clearing (SC) and flooding $(\mathrm{F})$, and snowmelt (SM) observed in the time-lapse images are noted as well as a spike due to air temperature (AT). 90

Figure 4.7 Plot of daily mean temperature at about $60 \mathrm{~cm}$ depth in the watercourse and near the lake outlet; air temperature at 6-hr intervals for clarity; and hourly ground surface temperature measured at P23 from October 1, 2013 to February 15, 2014. The shaded boxes represent the observed overflow events

Figure 4.8 Active-layer thicknesses measured at the sites in September 2012 and 2013. Measurements are grouped by year and by location on ROW (left) and off ROW (right). The box and whisker plots present median, minimum, maximum, lower quartile, and upper quartile active-layer thicknesses of $\mathrm{n}$ measurements. 93

Figure 4.9 Observations of surface water at P23: (a) the watercourse flowing toward the instrument site (denoted by white arrow), (b) surface water (denoted by white arrow) in a depression adjacent to P23-ROW (denoted by the GPS with flagging tape). Photos by W. Sladen (2012). 94

Figure 4.10 Examples of subsurface water and icings in February 2014. (a) Water in the drill hole at P23 that rose to $1 \mathrm{~cm}$ below the ground surface. The icing was $10 \mathrm{~cm}$ thick at this location. (b) White icing ice, $10 \mathrm{~cm}$ thick, over $17 \mathrm{~cm}$ of clear watercourse ice at P23. (c) Partial exposure of icing at P11, icing was $20 \mathrm{~cm}$ thick. Photos by W. Sladen. 96 
Figure 4.11 Co-isotope plot of samples collected at study sites, P11 and P23, and values reported in Michel (2011) $)^{1}$ and Gaanderse $(2015)^{2}$ for Yellowknife. GMWL $=$ Global meteoric water line: $\delta^{2} \mathrm{H}=8 \delta^{18} \mathrm{O}+10$ (Craig 1961), LMWL $=$ local meteoric water line: $\delta^{2} \mathrm{H}=6.9 \delta^{18} \mathrm{O}+19.2$ (Gibson and Reid 2010). ${ }^{1}$ Yellowknife precipitation value is an average annual-weighted isotopic composition for the period 1989 - 1998 (Michel 2011). ${ }^{2}$ Yellowknife rainfall values represent summer isotopic compositions (Gaanderse 2015) 99

Figure 4.12 Select geochemical data for icing ice, surface and subsurface water at portages 11 and 23. Samples from P11 and P23 were collected on February 17 and 16,2014 , respectively. Ionic composition is similar among samples but concentrations decrease during freezing possibly due to ion expulsion. 100

Figure 4.13 Time-lapse photographs of the largest overflow from each season. (a) First image of the December 3, 2012 overflow. (b) Day 2 of the December 3, 2012 overflow. (c) First image of the November 23, 2013 overflow. (d) Extent of November 23, 2013 overflow at the end of the first day. 103

Figure 4.14 Daily mean air temperature, overflow events and duration, snow accumulation, and freezeback at P23 from October 2012 to June 2013. The period of observed overflows is shaded in grey. P23-OFF is located in a raised bog $(\mathrm{FT}=$ $50 \mathrm{~cm}), \mathrm{P} 23-\mathrm{ROW}$ is located near the ROW in the overflow-affected area $(\mathrm{FT}=57$ $\mathrm{cm}$ ), and P23-TRA is the horizontal thermistor string and spans on and off the overflow-affected area $(\mathrm{FT}=58 \mathrm{~cm})($ Figure 3.6). Frost table $(\mathrm{FT})$ measurements were determined by probing and augering September 7, 2012. Snowfall at Yellowknife Airport (YZF) is included (Environment Canada 2016) 106 
Figure 4.15 Daily mean air temperature at P16S, snow accumulation, overflow events and duration, and freezeback at P23 from October 2013 to June 2014. The period of overflow observations is shaded in grey. P23-OFF is located off ROW in a raised bog, $\mathrm{P} 23-\mathrm{ROW}$ is located near the ROW in the overflow-affected area $(\mathrm{FT}=$ $52 \mathrm{~cm}), \mathrm{P} 23-\mathrm{TRA}$ is the horizontal thermistor string and spans on and off the overflow-affected area $(\mathrm{FT}=50 \mathrm{~cm})$, and P23-OFF2 is off ROW in the overflow area $(\mathrm{FT}=51 \mathrm{~cm})($ Figure 3.6). Frost table $(\mathrm{FT})$ measurements were determined by probing and augering September 6, 2013. Snowfall at Yellowknife Airport (YZF) is included (Environment Canada 2016). 107

Figure 4.16 (a) Ground temperature record at 15, 30, and $60 \mathrm{~cm}$ depth at P23-ROW from November 1, 2013 to January 31, 2014. Black arrows mark the date of overflows; the grey arrow marks the TCWR flooding of the road. (b) The three-stage ground thermal signal in response to the December 3-7 overflow: (1) temperature increase due to flooding of overflow water; (2) temperature remains near $0{ }^{\circ} \mathrm{C}$ as overflow water freezes and latent heat is released; and (3) ground temperatures decrease rapidly due to bare ice surface.

Figure 4.17 Plots of overflow history $(2005 / 06$ - 2013/14) for the southern portion of the TCWR and period weather: summer rainfall (Jul-Aug); autumn rainfall (Sep-Oct); snowfall (Oct-Dec); mean air temperature (Oct-Dec); and warming periods $\geq 5{ }^{\circ} \mathrm{C}$ (Oct-Feb) for Yellowknife Airport. The Cameron River winter yield (Nov-Mar) is also included (Environment Canada 2016, 2017). Overflow events are distinguished between P11, P23, and other portages. The 1981-2010 normals are denoted by the dashed lines. 
Figure 5.1 Meteorological record at Yellowknife Airport from 1942 to 2015 showing the trends in summer (Jul-Aug) and autumn (Sep-Oct) rainfall, early winter snowfall (Oct-Dec), and early winter mean air temperature (Oct-Dec) (Environmental Canada 2016). 126

Figure 5.2 The overflow cycle. Freezeback initiates the cycle by reducing the hydraulic transmissivity of the unfrozen ground which restricts water flow and results in increased hydraulic potential. The increased hydraulic pressure causes water to overflow onto the ground or ice surface which reduces the hydraulic potential. Freezeback continues causing the cycle to repeat itself until either hydraulic pressures are insufficient to breach the ground and ice surface or freezeback cuts off water flow.

Figure 5.3 Schematic showing the thermal and hydrological conditions involved with icings in the Great Slave Uplands. (a) Summer showing flow from a lake through the active layer with most flow occurring near the surface (large arrows). (b) Early freezeback when restricted water flow through the active layer causes an increase in hydraulic potential and results in overflow. (c1) Icing formation ceases due to hydraulic head being insufficient to breach ground and ice surface downslope. (c2) Icing formation ceases due to shut off of water flow by freezeback. Not drawn to scale. 129

Figure 5.4 Schematic showing conceptual flow connectivity within a drainage basin in winter. Lakes are ice covered. Lakes 1-4 are connected hydrologically at the start of winter, whereas Lakes 5-7 are not. Depending on the thermal and hydrological conditions between these lakes, icings may occur at some locations but not at 
others. The variability in these conditions may lead to variability in the timing of flow shut off between lakes and result in disruption of the hydrological connectivity

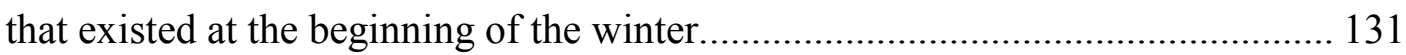




\section{List of Tables}

Table 2.1 Thermal conductivity and heat capacity of select soil materials. 16

Table 3.1 Summary of dates with at least one good time-lapse image taken at the sites from September 2012 to June 2014 and percent of good images available during each freezing season (FS). 58

Table 4.1 Correlation analyses for daily mean air temperatures at the study sites and the Yellowknife Airport (YZF) for September 2012 to June 2016 and fitted principal axes: (a) coefficient of determination, $\mathrm{r}^{2}$; (b) slope of the principal axis; (c) intercept of the principal axis; and (d) number of observations. 75

Table 4.2 Freezing season $\left(\mathrm{FS}_{\mathrm{A}}\right)$, mean temperature, and freezing degree days $\left(\mathrm{FDD}_{\mathrm{A}}\right)$ based on air temperatures for Yellowknife Airport (YZF) and the study sites for 2012/13, 2013/14, and the 1989-2010 average (Environment Canada 2016). 77

Table 4.3 Summary of subfreezing warming periods $\geq 5^{\circ} \mathrm{C}$ at $\mathrm{P} 11$ for the $2012 / 13$ and 2013/14 freezing seasons. 78

Table 4.4 Correlation analyses for snow accumulation at P11, P23, and Yellowknife Airport (YZF) for 2012/13 and fitted principal axes: (a) coefficient of determination, $\mathrm{r}^{2}$; (b) slope of the principal axis; (c) intercept of the principal axis; and (d) number of observations for the freezing season (Oct-Apr) and the period of

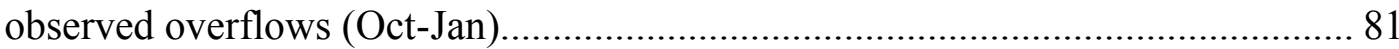

Table 4.5 Annual mean temperatures near the top of permafrost $\left(\mathrm{T}_{\mathrm{TOP}}\right) . \mathrm{NA}=$ not applicable, $\mathrm{ND}=$ no data. 85

Table 4.6 Summary of active-layer freezeback (FB) at the study sites for 2012/13 and

$2013 / 14$ 86 
Table 4.7 Summary of borehole sample depths and gravimetric moisture contents (MC) determined on a wet-weight basis for borehole samples. VI = visible ice content; $\mathrm{Vx}=$ visible ice crystals; $\mathrm{Nb}=$ ice bonded, not visible.

Table 4.8 Summary of the TCWR seasonal snow clearing and flooding of the portage sites for the study period. Date represents the first snow clearing and flooding observed in the time-lapse imagery. ND = no data available 102

Table 4.9 Summary of overflow events observed in the time-lapse photographs at P23. The date and time denote the first image when water was observed on the ground or snow surface, however, the overflow may have started earlier when images were either unavailable or undecipherable. $\mathrm{ND}=$ insufficient data. 104

Table 4.10 Total seasonal rainfall recorded at Yellowknife Airport (Environment Canada 2016) and period of observed overflow duration at P23 for 2012/13 and 2013/14. 


\section{Chapter: OVERVIEW AND OBJECTIVES}

\subsection{Introduction}

This thesis examines the factors influencing icings along winter roads in the Great Slave Upland region, NT. An icing is a sheet-like mass of layered ice formed by the freezing of successive overflows of water that may seep from the ground, flow from a spring, or emerge from below river ice (NRC 1988, Hu and Pollard 1997a). Icings are widespread in northern Canada, especially in permafrost regions where the presence of perennially frozen ground acts as an aquitard (Carey 1973). Field investigations were carried out along the Tibbitt to Contwoyto Winter Road (TCWR), northeast of Yellowknife to study the timing of overflows and investigate potential controlling factors such as air and ground temperature, active-layer freezeback, rainfall, snow accumulation, and winter road operations (Figure 1.1). The TCWR has been in operation since the 1970s originally for transportation of freight from Yellowknife, NT, to Lupin Gold Mine on Contwoyto Lake, NU, but more recently to transport goods to several diamond mines in the region.

Icings are typically defined by their source as river, ground, or spring icings (Carey 1973). They form in winter when the flow path from a reservoir becomes constricted causing water to emerge or overflow onto the ground or ice surface (Williams and Smith 1989). For groundwater, the obstruction may be seasonal frost penetration meeting an impermeable layer such as the top of permafrost, while for surface water it may be the merging of river ice with its bed (Muller 1945). Icings continue growing throughout the winter until either the source water is exhausted or the conduit is cut off (Pollard and van Everdingen 1992). Icings tend to recur at the same locations but not 


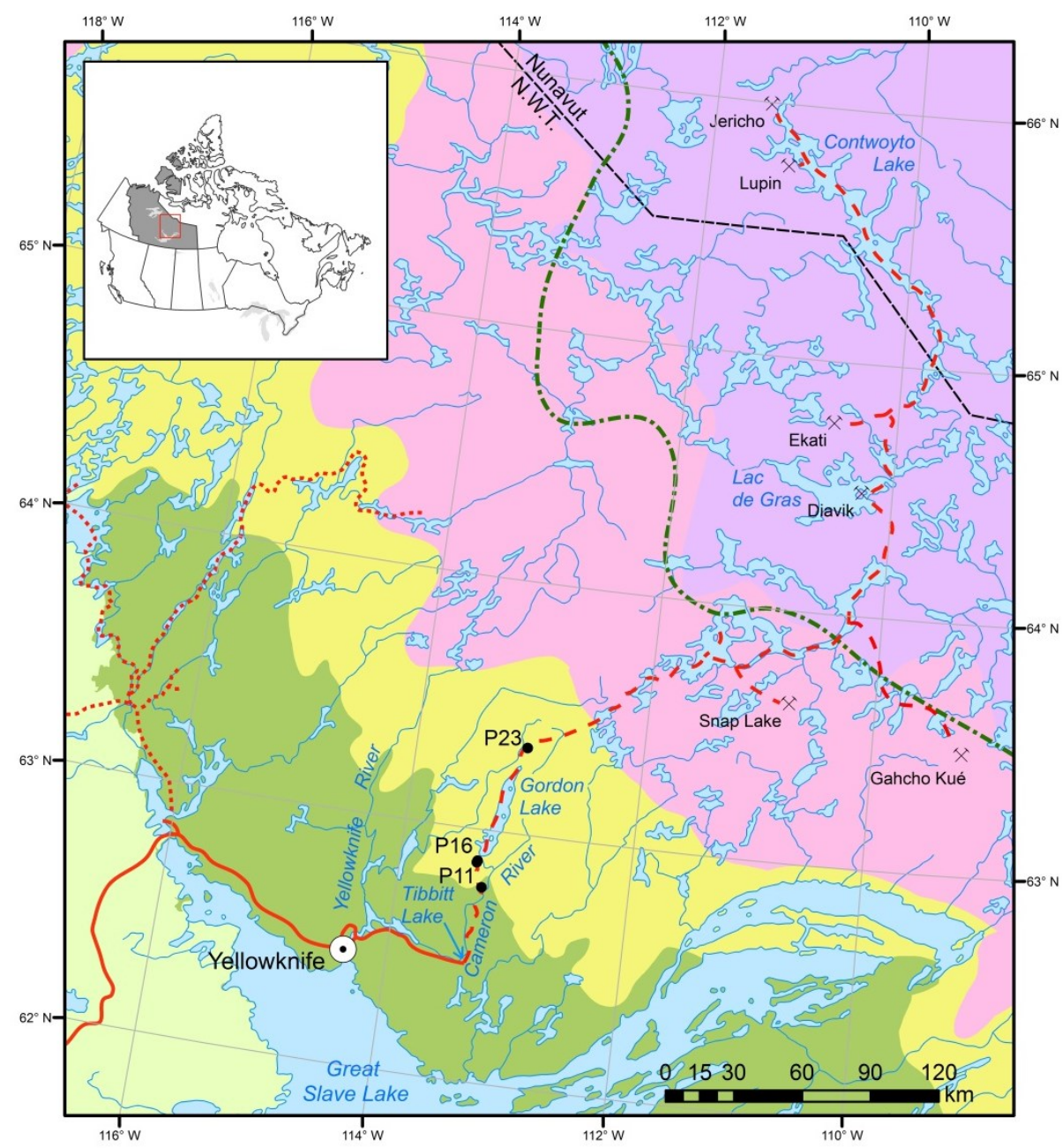

\section{Legend}

- Study Site

父 Mine

$\odot$ City

- - - Tibbitt to Contwoyto Winter Road

Winter Road

All Season Road

\section{Ecoregions}

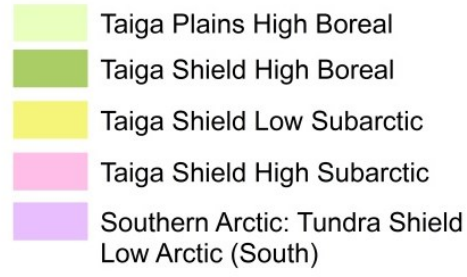

Figure 1.1 Ecoregions in the Great Slave Uplands and the Tibbitt to Contwoyto Winter Road (adapted from Ecosystem Classification Group 2008, 2012). Study portages are indicated. 
necessarily annually nor with the same spatial extent (Kane and Slaughter 1973, Morse and Wolfe 2015). The main controls on icings are hydrology, geology, topography, and climate; the combination of these elements may either lead to, or preclude, the occurrence of icings (Carey 1973, Pollard and van Everdingen 1992).

Icings are of particular interest because they may create a safety hazard near roads, railways, or buildings and result in costly maintenance (Figure 1.2) (van Everdingen 1978). In the thaw season, ice-blocked river channels or drainage structures may lead to flooding and erosion (Carey 1973, Saarelainen 2008), adding significantly to highway maintenance operations (Eager and Pryor 1945, van Everdingen 1982a, Saarelainen 2008). Water overflowing onto the winter road surface during the operating season is a principal challenge and a recurrent problem for the TCWR (C. Ambrose, pers. comm. 2012). Considering the increasing demand for new roads and improved all-season and winter roads in the Northwest Territories, better understanding of the factors driving overflow is necessary for planning and mitigation of the hazards caused by icings.

This thesis examines the relations between ground icings and air and ground temperature, rainfall, snowpack, and winter roads in the Great Slave Uplands. The term overflow is used to denote the process of water flowing onto the surface. Freezing of the overflow water forms an icing.

\subsection{Background}

Although icings were originally thought to be most prevalent in mountainous terrain (Pollard and van Everdingen 1992), recent mapping has shown that they are extensively distributed in the moderate relief of the Great Slave region (Morse and Wolfe 2015). To 


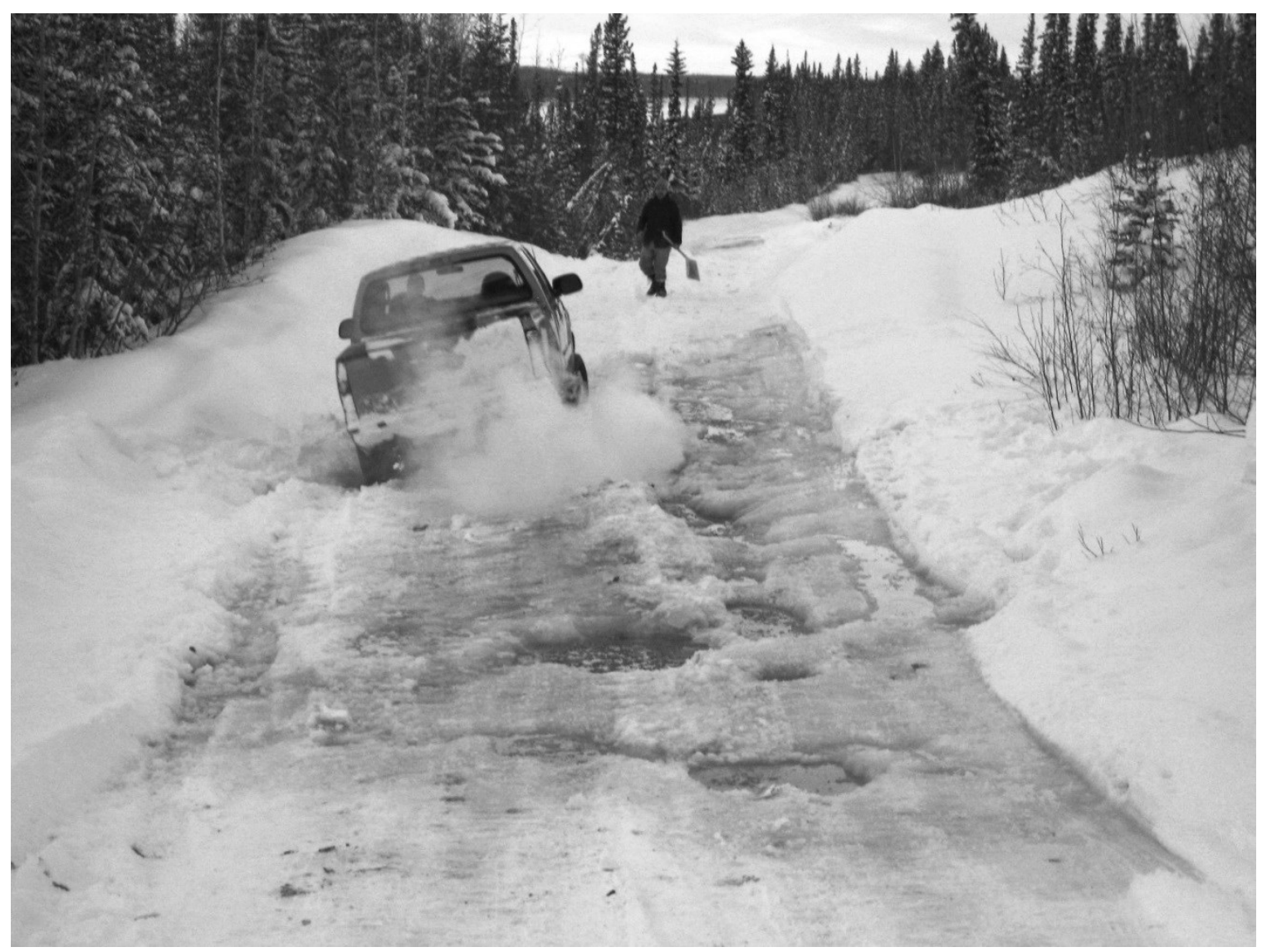

Figure 1.2 Icing on the Mackenzie Valley winter road south of Tulita in February 2006. Photo by W. Sladen. 
study this phenomenon, the development of ground icings at portages 11, 16, and 23 of the TCWR is considered in this thesis (Figure 1.1). The factors that may contribute to icings at the TCWR sites are as follows:

1) Winter baseflow is required for icings (Morse and Wolfe 2017). In permafrost regions, ground icings may derive their water from suprapermafrost, intrapermafrost, or subpermafrost aquifers (Carey 1973) (Figure 1.3). Suprapermafrost water-fed icings tend to stop growing before the end of the winter season when the source water is depleted or the conduit freezes shut, whereas subpermafrost water-fed icings may continue growing through the winter resulting in extensive icing formations (Pollard and van Everdingen 1992). Morse and Wolfe (2015) found icings to be statistically related to autumn rainfall in the Great Slave region, which is coincident with previous observations of elevated winter baseflow resulting from increased September rainfall in the area (Spence et al. 2011). The positive relations between rainfall and both winter baseflow and icings are partly due to the surface-water dominated hydrology of the subarctic Canadian Shield, which has a threshold-mediated flow regime, where outflow is generated once the storage threshold is exceeded (Spence and Woo 2006, Woo and Mielko 2007). Therefore, surface water stored in lakes may be important for icing development in the Great Slave Uplands.

2) Icing activity has been associated with air temperature fluctuations. Kane (1981) observed a direct relation between increases in pore-water pressure and subfreezing air temperature adjacent to a stream in Alaska. In the Great Slave region, Morse and Wolfe (2015) found inter-annual variation in icing number and 


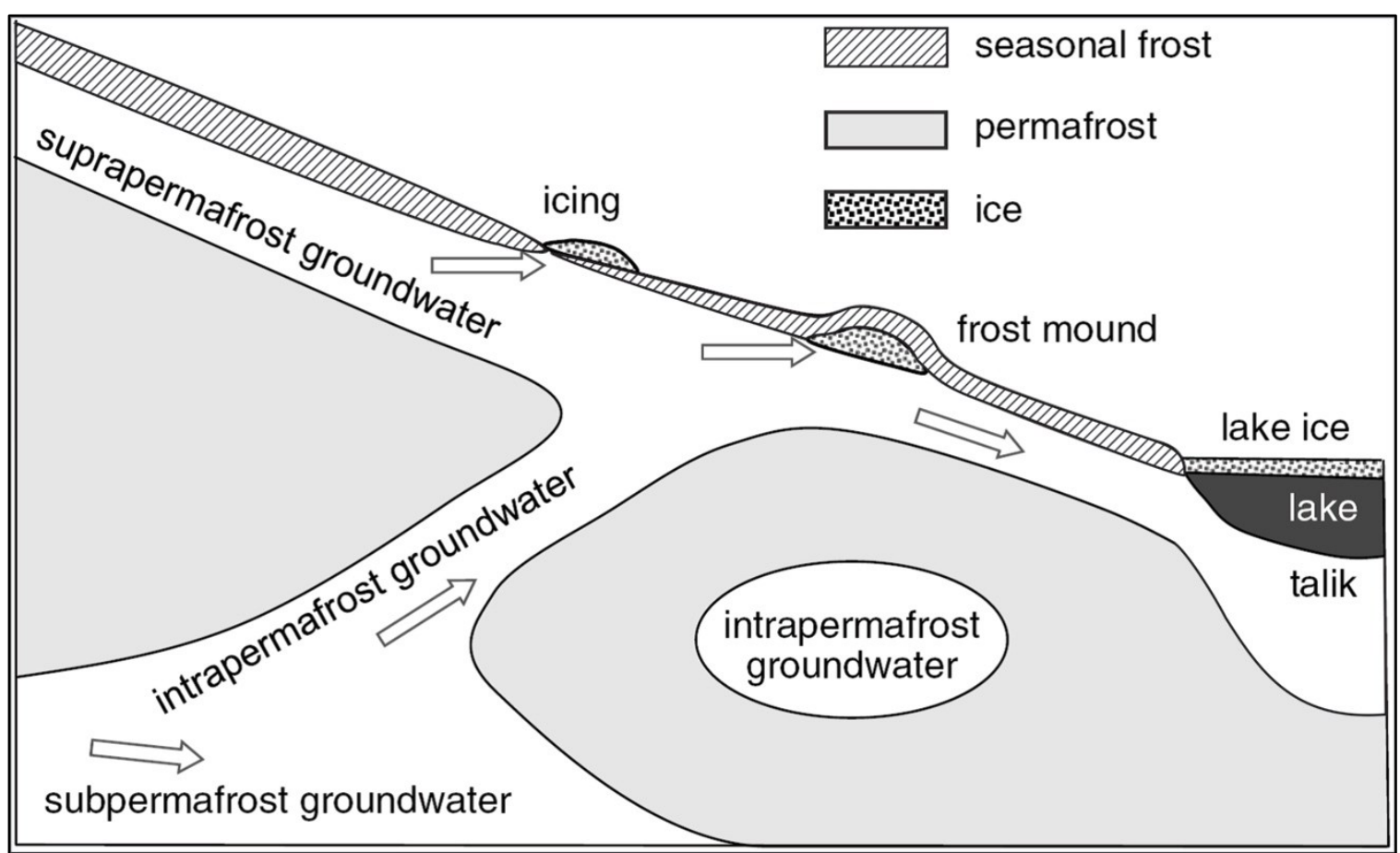

Figure 1.3 Occurrence of groundwater in permafrost: suprapermafrost, intrapermafrost, and subpermafrost (after Woo 2012, Fig. 3.1, p. 74). 
size was related to the annual frequency of winter warming periods. Van Everdingen (1982a) observed that icing activity decreased during periods of very cold weather, which he associated with freezing of the source water.

3) For overflows that initiate from the subsurface, climate-driven surface and ground temperatures may be important. Despite the relation observed between air temperature fluctuations and icing activity, the influence of ground temperature fluctuations on icings have not been previously investigated.

4) Ground icings have been attributed to increased hydraulic potential in the active layer due to freezeback (e.g., Carey 1973, Pollard and French 1984). Winter piezometer and frost-tube measurements adjacent to a stream in Alaska showed a general rise in the hydrostatic head with penetration of the freezing front (Kane et al. 1973).

5) At the event scale, the added weight of snow has been linked with increased potential water levels leading to overflow (Kane 1981, Price 1983). At the seasonal scale, thicker snow packs in early winter have been inversely related to icing activity (Yoshikawa et al. 1999, Vinson and Lofgren 2003), while thick snow cover during the latter part of winter has been observed to be favourable for icing formation (Chekotillo 1949).

6) Winter roads have been observed to affect the thermo-hydrological properties of the ground, creating conditions conducive for icing development (Carey 1973, van Everdingen 1978). The absence of vegetation and clearing of snow in winter enhance freezeback and promote permafrost aggradation. Vehicular loading may 
cause compaction of the subsurface materials resulting in reduced hydraulic conductivity. Both these processes may cause damming of subsurface water flow and lead to icings.

\subsection{Research objectives}

The purpose of this research is to investigate the factors controlling icings at three sites along the TCWR in the Great Slave Uplands. In order to accomplish this, the specific research objectives of this thesis are to:

1) determine the timing and duration of overflow; and

2) examine the relations between the timing of overflow and air temperature, ground temperature, rainfall, snow accumulation, active-layer freezeback, and winter road operations at the study sites.

The hypotheses to be tested in this thesis are:

1) freezeback of the ground beneath the winter road causes icings along the TCWR;

2) the timing of overflows in the Great Slave Uplands is related to air temperature fluctuations; and

3) the temporal extent of overflow occurrence is limited by the depth of the freezeback.

\subsection{Methods}

Three sites with a history of icings were selected along the TCWR for observation. A fourth site was selected as a control site where there was no history of icing activity prior 
to this study. The sites are in broad low-lying organic-rich valleys surrounded by rounded bedrock uplands, typical of the subarctic Canadian Shield landscape.

A wildlife camera was installed at each site with a view of the probable icing area. A graduated snow stake was placed within the camera's field of view. Time-lapse photographs were used to determine the timing and duration of overflows and the development of the snowpack. Air and near-surface temperature sensors were installed at each site in September 2012 to determine variations in air and near-surface ground temperature and the start of freezeback for each site. Temperature sensors were placed in the active layer on and off the TCWR right-of-way (ROW) to determine variations in ground temperature and the timing of active-layer freezeback in disturbed and natural terrain, respectively. All temperature sensors were connected to data loggers to record throughout the winter. Temperature measurements and time-lapse images were collected for winters 2012/13 and 2013/14. The depth of the active layer was measured by probing at each site in early September 2012 and 2013. The snow depth and density were measured in February 2013 and 2014. Seasonal rainfall for the study period was obtained from the Yellowknife Airport meteorological records. The timing and duration of overflows were examined in relation to air and ground temperature fluctuations, snowpack development, rate of freezeback, rainfall, and winter road construction. In addition, TCWR maintenance logs for winters 2005/06 to 2012/13 were reviewed for reference to overflow problems. This approach extended the icing observation record by seven years. Overflow incidents recorded in the logs were analyzed in relation to the meteorological record at Yellowknife Airport. 


\subsection{Thesis structure}

This thesis comprises six chapters. The following chapter outlines icing processes and controlling factors, subarctic Canadian Shield hydrology, and winter road operations. Chapter 3 describes the study region and methodology. Chapter 4 presents the field observations and analyses results. Chapter 5 provides a discussion of the results. Finally, Chapter 6 summarizes the conclusions and presents areas for further research. 


\section{Chapter: BACKGROUND}

\subsection{Introduction}

A study of icings in the Great Slave Upland region of the extensive discontinuous permafrost zone requires an understanding of: (1) permafrost and active-layer thermal regime; (2) active-layer freezeback; (3) active-layer hydrological regime; (4) icing processes; and (5) northern Canadian Shield hydrology. This chapter provides a background on winter active-layer dynamics, icings, and the hydrology of the region.

\subsection{Permafrost and the active layer}

Permafrost is a thermal condition of the ground defined as soil or rock that remains at or below $0{ }^{\circ} \mathrm{C}$ for two or more consecutive years (NRC 1988). The depth to the base of permafrost (Figure 2.1) is partly controlled by heat flow from the interior of the earth, or the geothermal flux (French 1996). The ground above permafrost that freezes and thaws annually is called the active layer. Frozen hydraulic conductivity is several orders of magnitude lower than thawed hydraulic conductivity for saturated porous materials, due to the presence of ice in the soil pores, which causes subsurface water flow to be concentrated within the unfrozen portion of the active layer (Carey and Woo 2005, Woo 2012). In permafrost environments, suprapermafrost hydrological activity is related to the thermal processes occurring within the active layer. Understanding the active-layer thermal regime is fundamental to the study of icings in permafrost environments.

\subsubsection{Active-layer thermal regime}

The thermal regime of the active layer can be divided into four seasons: (1) snow melt (early spring); (2) thaw season (spring and summer); (3) freezeback (fall and early winter); and (4) the frozen season (mid to late winter) (Figure 2.2) (Outcalt and Hinkel 


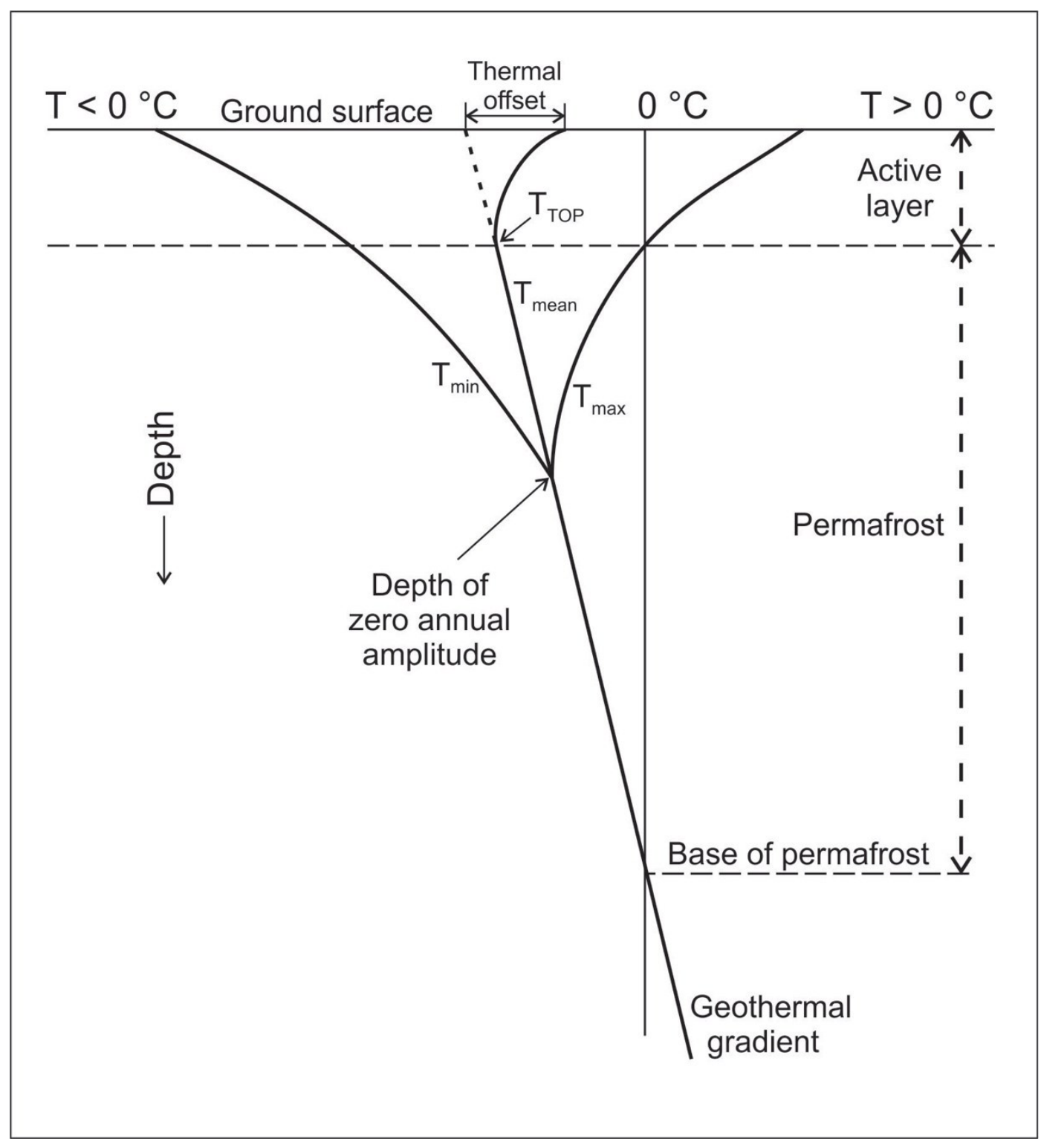

Figure 2.1 Schematic ground temperature profile describing the thermal regime of permafrost terrain. $T_{\text {mean }}, T_{\min }$, and $T_{\max }$ are respectively the mean, minimum, and maximum ground temperatures at depth. $\mathrm{T}_{\mathrm{TOP}}$ is the temperature at the top of permafrost (after Burn 2004, Fig. 3.3.2, p. 393). 


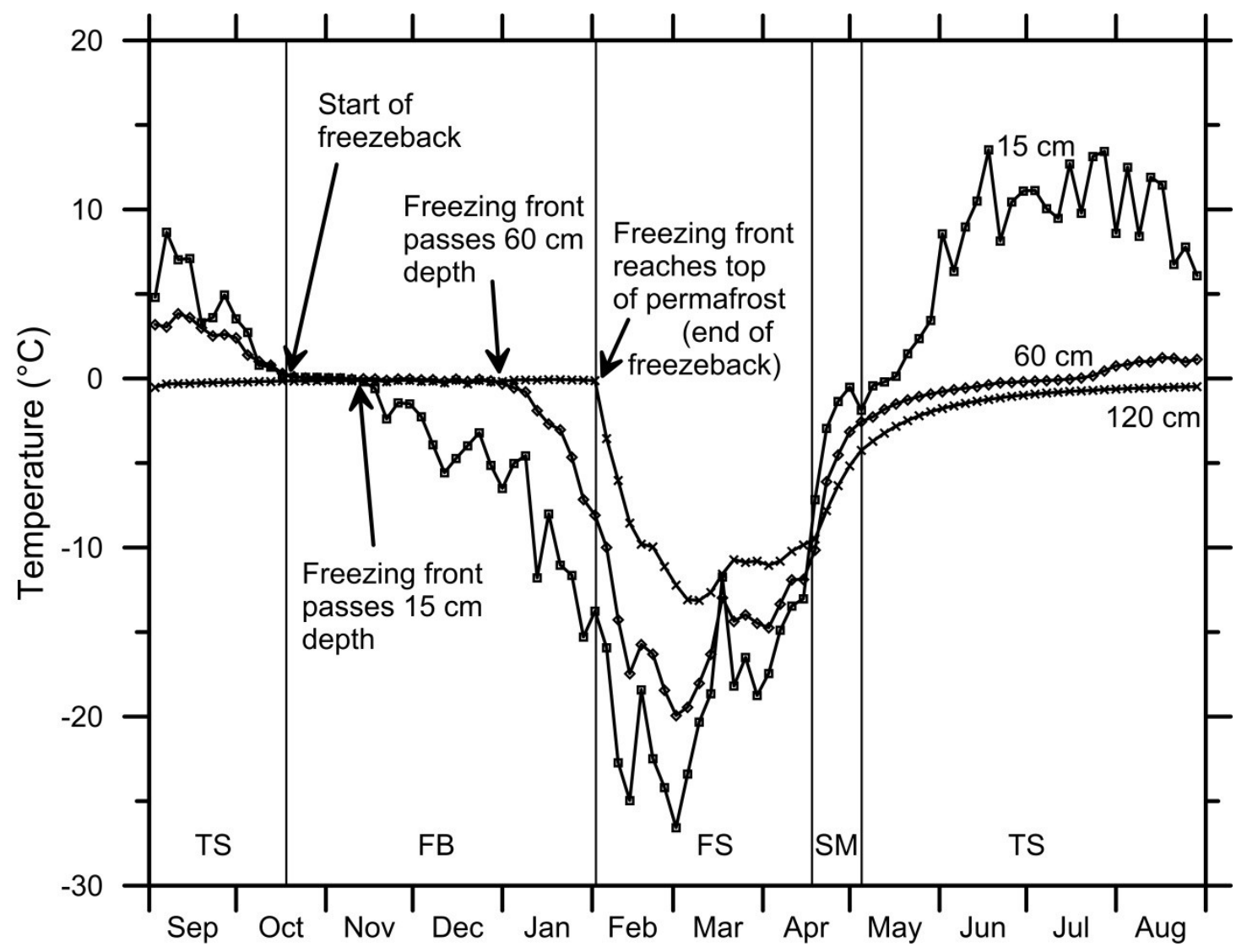

Figure 2.2 Daily mean ground temperatures at site P16N (P16N-ROW) for September 2013 to 2014. Readings are shown every four days for clarity. The thermal seasons of the active layer: snowmelt (SM), thaw season (TS), freezeback season (FB), and the frozen season (FS) are shown, as well as progression of the freezing front. The $120 \mathrm{~cm}$ depth sensor is in permafrost. 
1996). In early spring, active-layer temperatures increase rapidly with the onset of snowmelt. Later in spring, once the snow has disappeared and the ground surface temperatures rise above $0{ }^{\circ} \mathrm{C}$, the soil in the active layer begins to thaw from the surface downwards. The thickness of the active layer is determined by the $0{ }^{\circ} \mathrm{C}$ isotherm and its maximum thickness is commonly reached in late August to early September in the Great Slave region.

In the autumn, when air temperatures fall below $0{ }^{\circ} \mathrm{C}$, ground surface temperatures commonly follow shortly after and freezeback of the active layer commences. Freezeback occurs from the ground surface downwards and may also occur from the top of permafrost upwards (Mackay 1983, Osterkamp and Romanovsky 1997), though the latter is less, because the temperature gradient in permafrost is generally not steep (Burn 2004). During freezeback, temperatures at a given depth in the active layer may remain at or slightly below $0{ }^{\circ} \mathrm{C}$ while the soil water freezes and latent heat is released (Outcalt and Hinkel 1996). This effect is called the zero curtain and its duration is prolonged in soils with high water contents (Williams and Smith 1989). Once freezing of the soil water has occurred in the upper portion of the active layer, the temperatures in that portion may decrease rapidly. The end of the freezeback period and the start of the frozen season occur when the temperatures at the top of permafrost begin to decrease rapidly with closure of the zero curtain and the release of sensible, instead of latent, heat (Romanovsky and Osterkamp 1995). The freezeback period may be prolonged where there is advective heat transfer from subsurface water flow (Carey and Woo 2005).

As water freezes in the cracks and pores of the soil with the onset of the freezing season, an impermeable cap at the surface develops that thickens as the active layer 
freezes. The growth of this frozen layer restricts water flow by reducing the transmissivity of the remaining unfrozen portion of the active layer, which increases the hydraulic potential and may lead to expulsion of water at the surface and the formation of icings (Pollard and French 1984, Pollard and van Everdingen 1992). Once the active layer freezes back, it is no longer hydrologically active. Therefore, the period of activelayer freezeback is a critical period for icing development.

\subsubsection{Thermal properties of the ground}

Thermal conductivity $(\lambda)$ is the ability of a material to conduct heat. Typical values for thermal conductivity and heat capacity for various soil components are listed in Table 2.1. Thermal conductivity increases with increased quartz content, density, and water or ice content (Farouki 1981, Burn 2004). For very porous materials, such as peat, thermal properties of the material infilling the pores dominate the ground thermal properties as $\lambda$ of ice is four times that for water and one hundred times that for air (Table 2.1). Therefore, the water content and its phase is an important control on the thermal conductivity of the ground.

The volumetric heat capacity $(\mathrm{C})$ is the amount of heat required or released to change $1 \mathrm{~m}^{3}$ of soil by $1{ }^{\circ} \mathrm{C}$. The heat capacity of a soil is the sum of its constituent capacities, weighted by their volumetric fraction (Table 2.1). Similar to $\lambda, \mathrm{C}$ is affected by mineral composition, bulk density, water content, and phase state (Burn 2004).

Thermal diffusivity $(\kappa)$ is the ratio of $\lambda$ to $\mathrm{C}$ and describes the rate of temperature change in a soil. At low water contents $\kappa$ is hindered by low $\lambda$ and at high water contents by high C (Williams and Smith 1989). In saturated soils, frozen $\kappa$ is greater than 
Table 2.1 Thermal conductivity and heat capacity of select soil materials.

\begin{tabular}{lll}
\hline Material & $\begin{array}{l}\text { Thermal Conductivity } \\
\left(\mathrm{W} \mathrm{m}^{-1}{ }^{\circ} \mathrm{C}^{-1}\right)\end{array}$ & $\begin{array}{l}\text { Volumetric Heat Capacity } \\
\left(\mathrm{J} \mathrm{m}^{-3}{ }^{\circ} \mathrm{C}^{-1}\right)\end{array}$ \\
\hline Air $\left(10^{\circ} \mathrm{C}\right)$ & $2.2 \times 10^{-2}$ & $8.6 \times 10^{2}$ \\
Water $\left(10^{\circ} \mathrm{C}\right)$ & $5.6 \times 10^{-1}$ & $4.2 \times 10^{6}$ \\
Ice $\left(0^{\circ} \mathrm{C}\right)$ & $2.2 \times 10^{0}$ & $1.9 \times 10^{6}$ \\
Quartz & $8.0 \times 10^{0}$ & $2.1 \times 10^{6}$ \\
Mica & $3.0 \times 10^{0}$ & $2.4 \times 10^{6}$ \\
Feldspar & $2.0 \times 10^{0}$ & $2.0 \times 10^{6}$ \\
Peat (dry) & $6.0 \times 10^{-2}$ & $5.8 \times 10^{5}$ \\
Peat (wet) & $5.0 \times 10^{-1}$ & $4.0 \times 10^{6}$ \\
Peat (wet, frozen $)$ & $1.1 \times 10^{0}$ & $1.6 \times 10^{6}$ \\
\hline
\end{tabular}

Data from Burn (2004, Table 3.3.1, p. 394) 
unfrozen $\kappa$, because the $\lambda$ of ice is greater than that of water and the $\mathrm{C}$ is lower (Table 2.1).

Latent heat must be released $\left(3.33 \times 10^{8} \mathrm{~J} \mathrm{~m}^{-3}\right)$ during freezing of water in soils before ground temperature can decrease below $0{ }^{\circ} \mathrm{C}$. The latent heat causes the soil to display an apparent heat capacity that is much larger than the volumetric heat capacity of the soil without a phase change (Williams and Smith 1989). Therefore, $\kappa$ is dominated by $\mathrm{C}$ between $0{ }^{\circ} \mathrm{C}$ and $-3{ }^{\circ} \mathrm{C}$ due to the relation between unfrozen water content and temperature (discussed in section 2.4.3).

\subsection{Active-layer freezeback}

Active-layer freezeback affects subsurface water flow and hydraulic pressure by reducing the cross-sectional area and therefore the hydraulic transmissivity of the unfrozen portion of the active layer (van Everdingen 1982b). The depth of the freezing front $\left(Z_{t}\right)$ at time $t$ since the start of freezing, assuming an initial surface temperature $\left(\mathrm{T}_{\mathrm{s}}\right)$ of $0{ }^{\circ} \mathrm{C}$, can be approximated using the Stefan solution (Kurylyk and Hayashi 2016):

$$
Z_{t}=\alpha \sqrt{\frac{2 \lambda t\left|T_{S}\right|}{\varphi L}}
$$

where $\alpha$ is the Stefan correction number, $\lambda$ is the thermal conductivity, $\left|T_{\mathrm{s}}\right|$ is the modulus of $\mathrm{T}_{\mathrm{s}}, \varphi$ is the volumetric water content, and $\mathrm{L}$ is the volumetric latent heat of fusion. The Stefan correction number for a surface temperature of $0{ }^{\circ} \mathrm{C}$ before freezing is determined by:

$$
\alpha=1-0.16 S+0.038 S^{2}
$$

and 


$$
S=\frac{C\left(\left|T_{S}\right|\right)}{L \varphi}
$$

where the dimensionless Stefan number, $\mathrm{S}$, is a ratio of sensible to latent heat. The rate of freezing front progression (freezeback) is:

$$
\frac{d Z_{t}}{d t}=\frac{\alpha}{2} \sqrt{\frac{2 \lambda\left|T_{S}\right|}{\varphi L t}}
$$

which indicates that the rate of freezeback decreases with time. The Stefan solution models downward freezing using a one dimensional heat conduction model and ignores convective heat flow (Kurylyk et al. 2014), which may be important when heat advection from subsurface water flow occurs (Carey and Woo 2005). The rate of freezing may be important for changes in transmissivity of the active layer especially in the early stages of freezeback when the rate of freezing is highest.

\subsection{Controls on active-layer freezeback}

\subsubsection{Air and ground surface temperature}

Air temperature $\left(\mathrm{T}_{\mathrm{a}}\right)$ governs ground surface temperature $\left(\mathrm{T}_{\mathrm{s}}\right)$ and therefore, the timing and level of $\mathrm{T}_{\mathrm{a}}$ below $0{ }^{\circ} \mathrm{C}$ govern the rate of freezeback. $\mathrm{T}_{\mathrm{s}}$, however, varies spatially due to buffering from $\mathrm{T}_{\mathrm{a}}$ by local vegetation, snow, and surface organic layer conditions (Luthin and Guymon 1974, Williams and Smith 1989). $\mathrm{T}_{\mathrm{s}}$ is a critical boundary condition in determining the timing and rate of freezeback.

\subsubsection{Snowpack}

Snow is the most important factor controlling the difference between $T_{a}$ and $T_{s}$ in winter (Goodrich 1982, Smith and Riseborough 2002). The low thermal conductivity of snow

limits the release of heat from the ground (Gold 1963, Sturm et al. 1997). Generally, the 
insulating capacity increases with snow thickness (Smith 1975) and decreases with snow density (Zhang 2005). Snow accumulation and density are affected by vegetation and wind; snow tends to be thinner and denser in open tundra areas, where it is affected by wind action, than in vegetated areas that inhibit snow transport. Near Yellowknife, freezeback of the active layer was observed to take between 30 and $100 \%$ of the freezing season due to snow depths greater than $40 \mathrm{~cm}$ and saturated active layers (Karunaratne 2011). In the Mackenzie Delta region, Palmer et al. (2012) observed freezeback duration to be positively related to snow depth. The earlier the establishment of the snowpack, the greater its insulating effects (Goodrich 1982, Zhang 2005, Palmer et al. 2012). A snowpack that starts early in the season and accumulates rapidly will reduce the release of heat from the ground and slow the rate of freezeback. Therefore, the timing and thickness of the snow are important factors controlling the rate of freezeback.

\subsubsection{Moisture content, unfrozen water, and soil texture}

The presence of soil water is an important factor affecting the thermal regime because it influences the seasonal ground thermal properties, affects the rate of freezeback and the depth of frost penetration through the release of latent heat, and facilitates nonconductive heat transfers (section 2.4.5). The moisture content of the ground determines the amount of latent heat that needs to be dissipated before cooling can occur (Woo 2012). Due to chemistry and particle-water energetics, water freezes back over a range of temperatures below $0{ }^{\circ} \mathrm{C}$ (Williams and Smith 1989). This unfrozen water content decreases with decreasing temperature in relation to soil texture. Silty and clayey soils can have a considerable amount of unfrozen water at temperatures below $-2{ }^{\circ} \mathrm{C}$ whereas sands and coarser-grained soils have low unfrozen water contents because most of the 
soil water freezes just below $0{ }^{\circ} \mathrm{C}$ (Williams and Smith 1989, Fig. 1.4, p. 7). The amount of unfrozen water affects the thermal properties of the soil (Farouki 1981) and the release of latent heat, which in turn protects the ground from rapid cooling and extends the freezeback period by slowing the change in ground temperature (Burn 1998, Romanovsky and Osterkamp 2000, Carey and Woo 2005). Prolonged freezeback means that the active layer remains hydrologically engaged for a longer period in winter (Kokelj et al. 2012).

\subsubsection{Peat}

Annual mean ground temperatures tend to be lower in peat terrain due to the seasonal variation in thermal properties of peat (Table 2.1) (Williams and Smith 1989). In the summer, the peat surface tends to be dry due to evaporation, resulting in very low $\lambda$. In addition, vapour distillation within the peat takes up heat, further cooling the ground (Nelson et al. 1985). The $\lambda$ of peat increases in the autumn as peat becomes wetter due to increased rainfall and lower rates of evaporation. Once saturated peat freezes, the increase in $\lambda$ further enhances ground cooling. Annual mean ground temperatures tend to be lower in peat environments than in areas without peat, thereby promoting the presence of permafrost (Wolfe et al. 1998).

The large pore space characteristic of peat contributes to its high hydraulic conductivity $(\mathrm{K})$ relative to other earth materials. The high infiltration rate of peat at the ground surface results in drainage of rainfall through the saturated zone above the permafrost table, rather than as surface runoff (Quinton et al. 2008). The high K combined with the large water-holding capacity of the peat means considerable amounts of water may be present at the time of freeze up. The combination of greater water 
content and lower $\lambda$ means that the effect of latent heat is much greater than in mineral soil (Nakano and Brown 1972). This in turn results in prolonging the freezeback period of the active layer.

\subsubsection{Lateral advective heat transfer}

Lateral advective heat transfer from water flow counteracts vertical conductive heat loss by importing heat (Carey and Woo 2005, Woo 2012). The lateral movement of water is driven by the hydraulic gradient and is typically restricted to the saturated zone above an impermeable layer (Kane et al. 2001). The effect of lateral water movement on shallow ground temperatures is related to the flow rates (Bense and Beltrami 2007). Frost depths are limited by the advective heat transfer due to continuous lateral water flow below the freezing front (Price 1983, Carey and Woo 2005). The forced convective heat transfer is higher in peats than in mineral soil due to higher $\mathrm{K}$ and lower unfrozen $\lambda$ (Kane et al. 2001). Latent heat effects and groundwater flow have been associated with prolonged freezeback (Hinkel and Outcalt 1994, Carey and Woo 2005). Prolonged freezeback due to lateral water flow is hydrologically important for icings because of the maintenance of subsurface flow channels in winter and availability of water.

\subsection{Icings}

Icings result from a seasonal hydrological process that occurs in climates where there is an extended period with air temperature below $0{ }^{\circ} \mathrm{C}$. Icings form on the ground or ice surface by freezing of successive overflows of water. Icings tend to recur in the same locations but neither annually nor to the same extent (Sloan et al. 1976, Slaughter 1982, Morse and Wolfe 2015). They are common in discontinuous permafrost where there is 
groundwater flow and permafrost creating a shallow barrier to flow (Woo 2012).

However, icings are not restricted to permafrost terrain (Williams and Smith 1989).

Icing ice may be transparent or white and opaque due to the presence of bubbles (Woo 2012). The ice may also have a brownish tint due to the water having passed through organic terrain (Yoshikawa et al. 2007, Woo 2012) or to solute exclusion during freezing. The ice layers commonly range in thickness from centimetres to metres (Williams and Smith 1989).

Icings have been reported to be most common in high latitude, mountainous terrain (Pollard and van Everdingen 1992), where icings form at or near the base of slopes (e.g., van Everdingen 1978, van Everdingen and Allen 1983, Clark and Lauriol 1997, Yoshikawa et al. 2007, Kane et al. 2013). However, recent research conducted in the Great Slave region has shown that icings are also common in low-relief terrain where maximum elevations reach $450 \mathrm{~m}$ a.s.1. and local relief is on the order of tens of metres (Morse and Wolfe 2015, 2017).

\subsection{Icing type}

Icings are divided into three main categories based on source water: ground icings, spring icings, and river or stream icings (Thomson 1966, Carey 1973, Pollard and van Everdingen 1992), but icings may be commonly formed from a combination of the three types (Kane and Slaughter 1973, Harden et al. 1977). The sources of icings have been determined by isotopic analysis, chemical composition, or the ratio of dissolved inorganic carbon to dissolved organic carbon (van Everdingen 1982a, Yoshikawa et al. 2007). 


\subsubsection{Ground and spring icings}

Ground icings form from the seeping of suprapermafrost or near-surface groundwater (Williams and Smith 1989). The source of this water is commonly limited in supply, thus icings stop growing before the end of winter, once the water is exhausted, or the conduit is shut off by freezing (Pollard and van Everdingen 1992, Woo 2012). The shape of ground icings is largely determined by the local topography (Thomson 1966, Carey 1973).

Spring icings form from perennial springs and are more common in mountainous terrain (Carey 1973). The source water tends to be deeper groundwater and in permafrost environments, to be subpermafrost or intrapermafrost in origin (Figure 1.3). The geologic conditions favouring spring icings are fault zones and pervious rocks (Carey 1973, Woo 2012). The springs commonly have defined water tracks on the ground surface (Woo 2012) and form at breaks in slope where the groundwater table intersects the ground surface (Pollard and French 1984). Spring icings tend to be larger than ground icings due to the continued supply of groundwater (Woo 2012).

The mechanism of formation for both ground and spring icings is similar. At the start of the freezing season, the ground surface freezes, creating a confining cap. As freezeback propagates downward towards a shallow layer of low permeability, such as clay, bedrock, or permafrost, groundwater flow becomes restricted, leading to the buildup of hydraulic pressure (van Everdingen 1978, Pollard and French 1984). Depending on local surface and subsurface conditions, water will emerge on the surface and freeze when exposed to air below $0{ }^{\circ} \mathrm{C}$ (Figure 2.3). If snow is present on the surface, it may be 


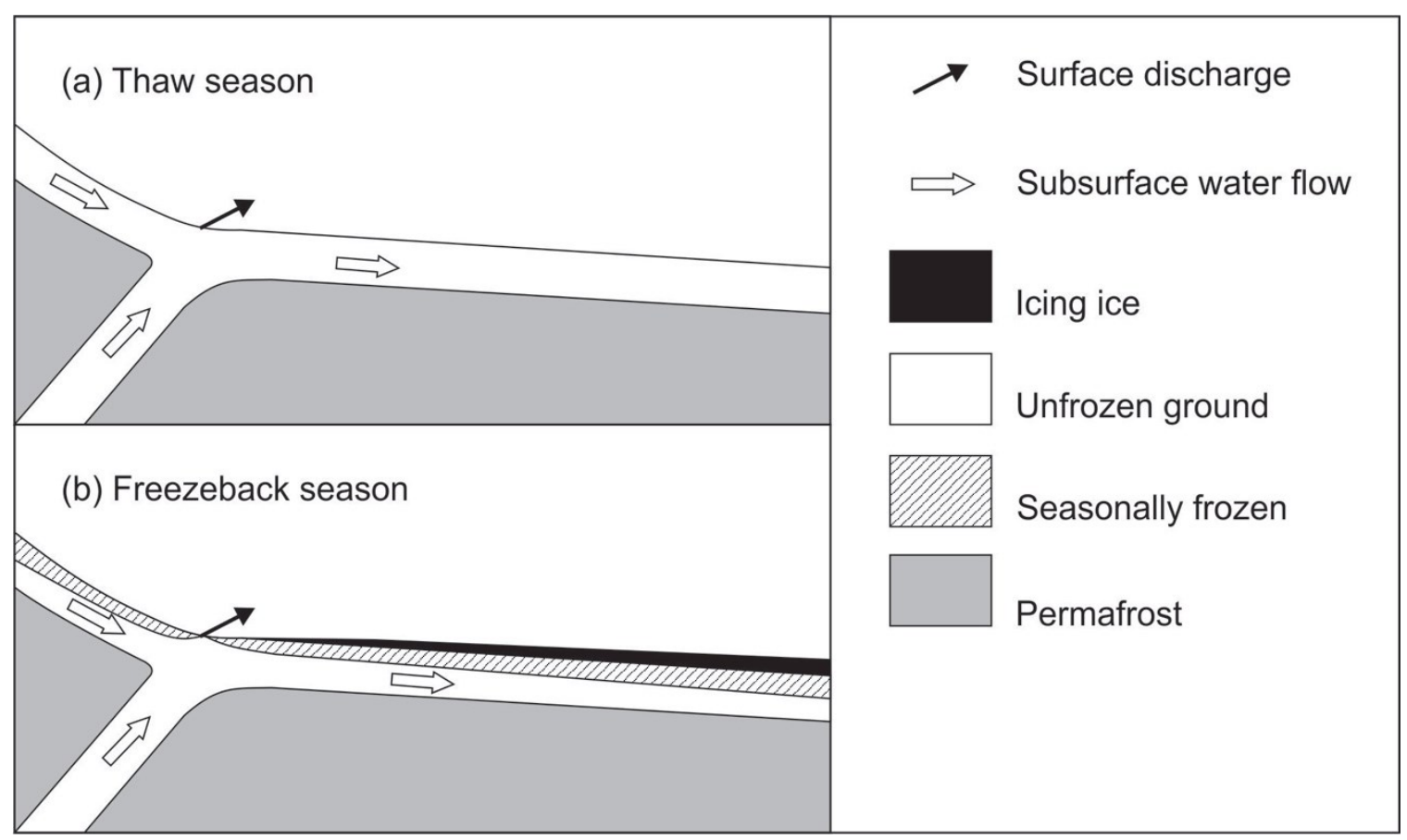

Figure 2.3 Schematic of ground or spring icing formation depicting the ground thermal and hydrological conditions in the (a) thaw season and (b) early part of the freezeback season (after van Everdingen 1982b, Fig. 18, p. 260). 
incorporated into the overflow. Overflow of water onto the surface may be continuous or intermittent (Carey 1973).

\subsubsection{River icings}

River or stream icings form in defined fluvial channels. Depending on whether the river channel is narrow and deep or shallow and broad, river icings may be very thick or very broad, respectively (Williams and Smith 1989). The source water may be from springs or groundwater that feeds the river. In discontinuous permafrost where there may be sustained baseflow, these icings continue to grow during the winter (Woo 2012).

The sequence of river icing development has been described by Kane (1981) and Hu and Pollard (1997b). As with ground icings, river icings develop after formation of the initial ice cover. As the ice cover thickens downward, the flow area becomes increasingly constricted leading to build-up of hydraulic pressure. If the pressure head is greater than the ice thickness, water will emerge on the surface through fractures and freeze.

\subsection{Icing growth}

Icing growth has been observed using several methods including field elevation measurements and aerial photos (e.g., Kane and Slaughter 1973), time-lapse photography (e.g., van Everdingen 1982a), and remote sensing (e.g., Yoshikawa et al. 2007). Icing growth commences after the start of the freezing season. Surveys in central Alaska revealed that stream icing growth commonly begins between the beginning of December and early January, two to three months after the start of the freezing season, and maximum growth is reached by March (Kane and Slaughter 1973). In southwestern 
Yukon, time-lapse photography indicated that icing growth commenced at the start of the freezing season in mid-October, and accelerated in mid-November reaching maximum thickness in February (van Everdingen 1982a). Therefore, icings initiate during the freezing season but their rate of development is variable.

\subsection{Controls on icing development}

\subsubsection{Water availability}

The primary element required for icings is a water source. In addition to this, the amount of water influences the formation and size of the icing. Icings have been observed to vary directly with the amount of autumn rainfall (Carey 1973), and year-to-year variability in icing area in the Great Slave region has been related statistically to the amount of rainfall preceding freeze-up (Morse and Wolfe 2015). In discontinuous permafrost there is greater connection between subpermafrost groundwater and nonpermafrost groundwater and therefore water is potentially available throughout the freezing season.

\subsubsection{Air temperature}

The second element required for icings is air temperature below $0{ }^{\circ} \mathrm{C}$. In addition to this absolute requirement, air temperature fluctuations below $0{ }^{\circ} \mathrm{C}$ have been statistically related to icing activity. For 30 years of icing activity in interior Alaska, Yoshikawa et al. (1999) found the frequency of air temperature fluctuations on the order of $15{ }^{\circ} \mathrm{C}$ to be positively related to the rate of icing development. In a similar long-term study, Morse and Wolfe (2015) found icing activity in the Great Slave region to be correlated significantly with the frequency of subfreezing warming periods (sum of consecutive daily increased air temperature) $\geq 5{ }^{\circ} \mathrm{C}$. Using this relation, Morse and Wolfe (2017) 
found that in a small subarctic, Canadian Shield drainage basin, near Yellowknife, icings occurred in years where there were 25 or more warming periods as long as there was winter baseflow (Figure 2.4).

At the study site scale, Kane (1981) conducted time series analyses on piezometer and air temperature measurements adjacent to a stream in central Alaska and found porewater pressures to vary with air temperature. Pore-water pressure decreased during cold spells and increased with warming and this response was observed to lag increasingly over time as ice thickened. Yoshikawa et al. (2007) also reported a link between overflow activity, observed from SAR images for the North Slope of Alaska, and air temperature fluctuations that occurred over a two-day period. Van Everdingen (1982a) suggested freezing of the upstream discharge was responsible for the decrease in icing activity during very cold temperatures in southwestern Yukon. Similar to Kane (1981), Price and FitzGibbon (1987) observed a rise in hydrostatic water level corresponding to a rise in subfreezing air temperatures in mid-December for a fen site in central Saskatchewan (Figure 2.5). Therefore, it appears that the processes controlling icings may be similar in permafrost and non-permafrost terrain. Studies over varying temporal and spatial scales have observed an association with winter warming periods. However, the mechanism behind the rise in pore-water pressure during periods of warming is not known, nor is it clear how the frequency of warming periods over an entire season relates to any one overflow.

\subsubsection{Freezeback and ground temperatures}

The expulsion of water onto the ice or ground surface has been associated with an increase in hydraulic pressure due to downward penetration of the freezing front reducing 

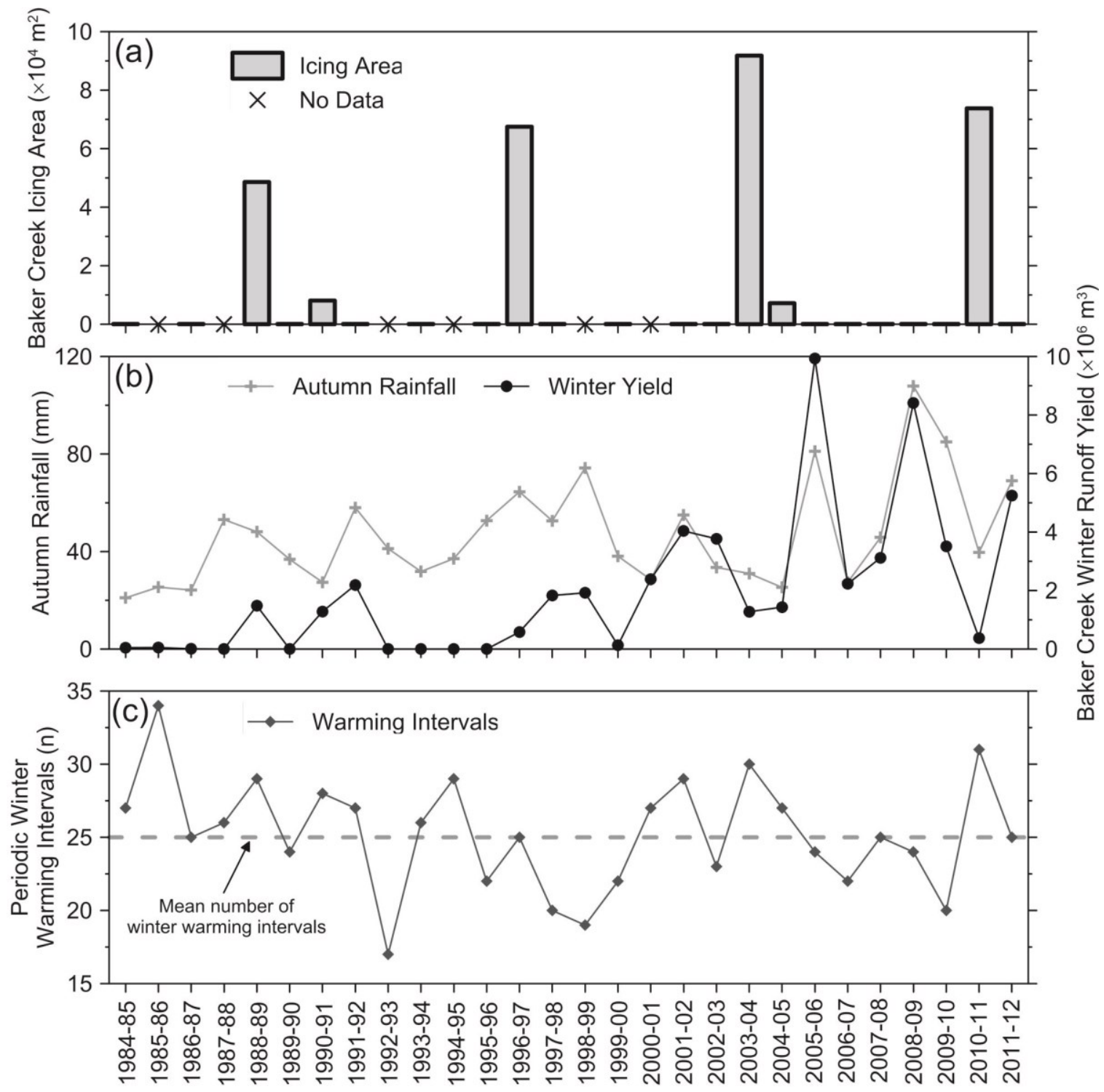

Figure 2.4 Time series of (a) icing area, (b) autumn rainfall and winter yield, and (c) warming periods for Baker Creek near Yellowknife, NT, from 1984/85 to 2011/12. For the years with data, icings were only observed when there was baseflow and the frequency of winter warming periods was greater than 25 (after Morse and Wolfe 2017, Fig. 3). 


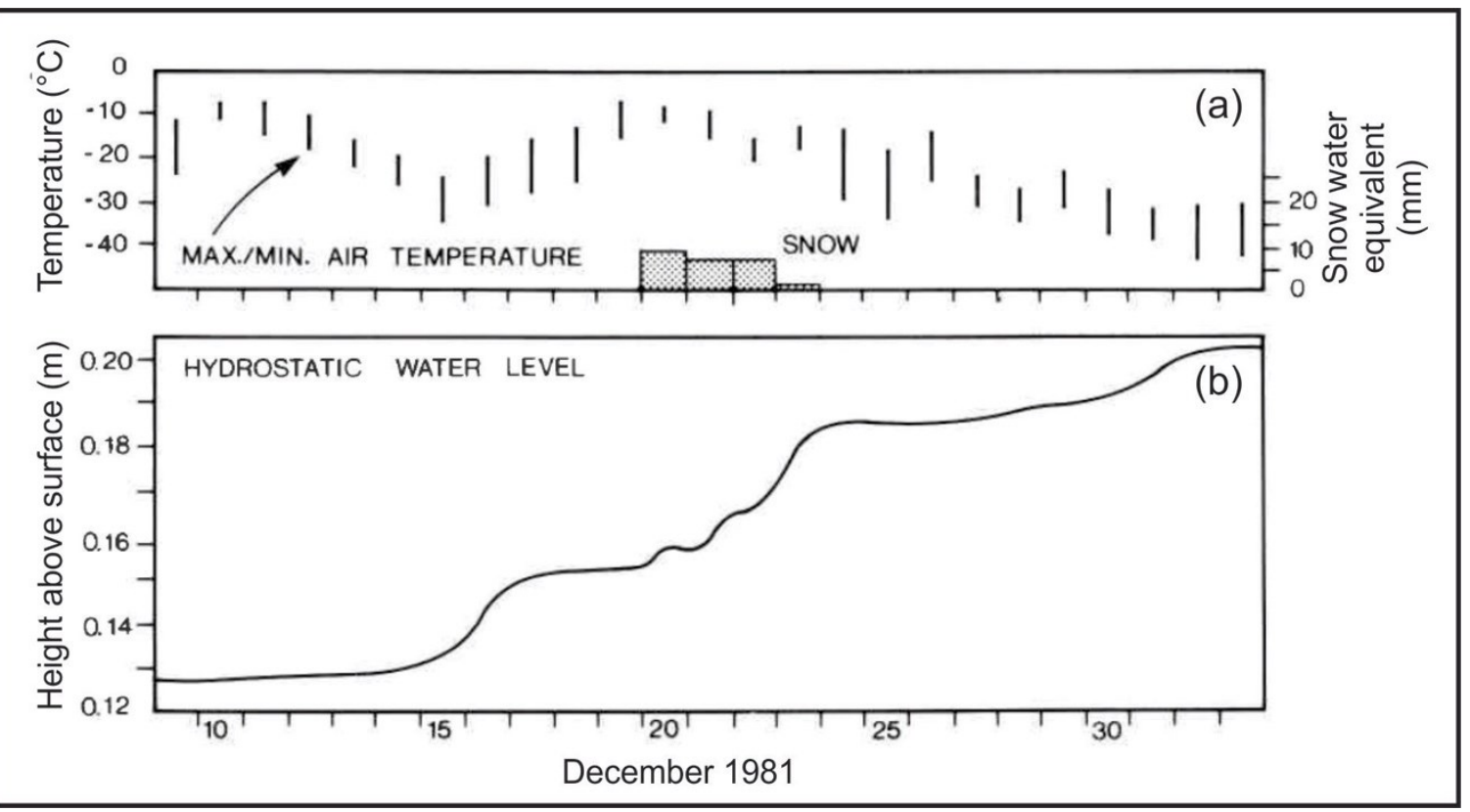

Figure 2.5 Time series showing (a) air temperature and snow, and (b) hydrostatic water level for December 9, 1981 to January 2, 1982. Plots show rising water level (December 15-16 and 22-23) coinciding with subfreezing warming periods following cooling periods (after Price and FitzGibbon 1987, Fig. 4, p. 2078). 
the hydraulic transmissivity of the remaining unfrozen ground (Chekotillo 1949, van Everdingen 1982b, Pollard and van Everdingen 1992). In discontinuous permafrost, pore-water pressures increased with seasonal frost penetration adjacent to a subarctic stream resulting in icing growth (Kane et al. 1973) (Figure 2.6). Similarly, in nonpermafrost terrain, Price and FitzGibbon (1982) observed a rise in hydrostatic water level with onset of surface freezing which led to groundwater seeps to the surface and the formation of icings. This occurred in fens where the freezing front was always in contact with saturated peat as opposed to bogs and mineral soils where the water table was below the freezing front (Figure 2.7). Price (1983) explained that the hydraulic pressure resulted from the expulsion of water from freezing peat, increased hydrostatic pressure from the snowpack, and artesian pressure resulting from the constricted water flow beneath the freezing layer. Therefore, the rate of freezeback and the ground surface temperatures that control it may be important as freezeback affects the rate at which the hydraulic transmissivity of the active layer is reduced.

\subsubsection{Snow accumulation}

Icing activity is observed to vary inversely with snow accumulation. Observations along the Alaska Highway showed few icings where snow depth was greater than $38 \mathrm{~cm}$ (Eager and Pryor 1945). Yoshikawa et al. (1999), using a 30-year record of icings in discontinuous permafrost of interior Alaska, observed no icing development during years when snowfall between October and December was greater than $100 \mathrm{~cm}$. Whereas in Denali Park, AK, Vinson and Lofgren (2003) determined a threshold of $50 \mathrm{~cm}$ of maximum snow accumulation during the same time period, above which icings did not occur. This observation agrees with those reported by Muller (1945). 


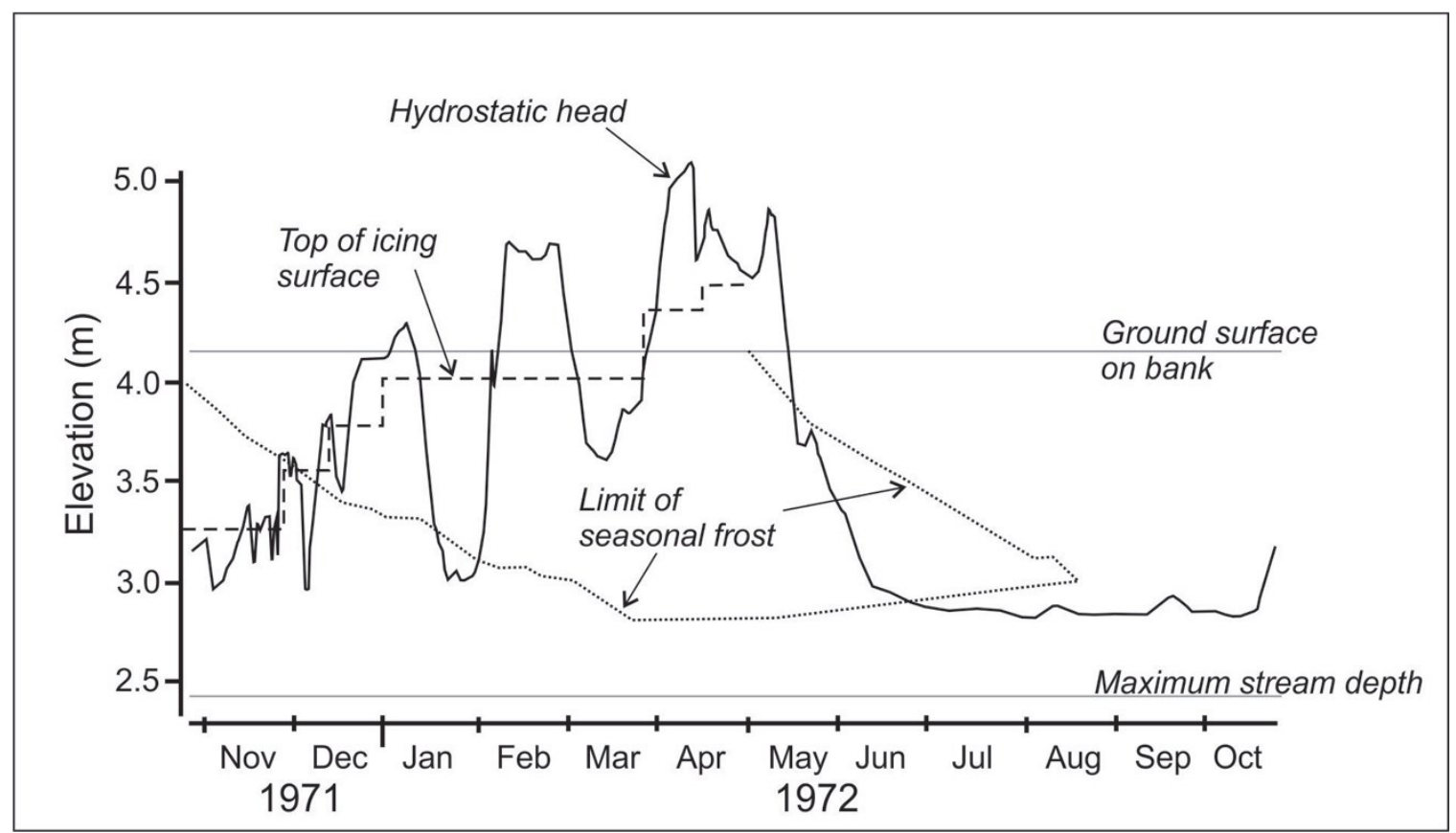

Figure 2.6 Time series plot showing hydrostatic head, frost penetration, and level of the icing surface from November 1971 to October 1972 (after Kane et al. 1973, Fig. 2, p. 455 and Fig. 4, p. 456). 


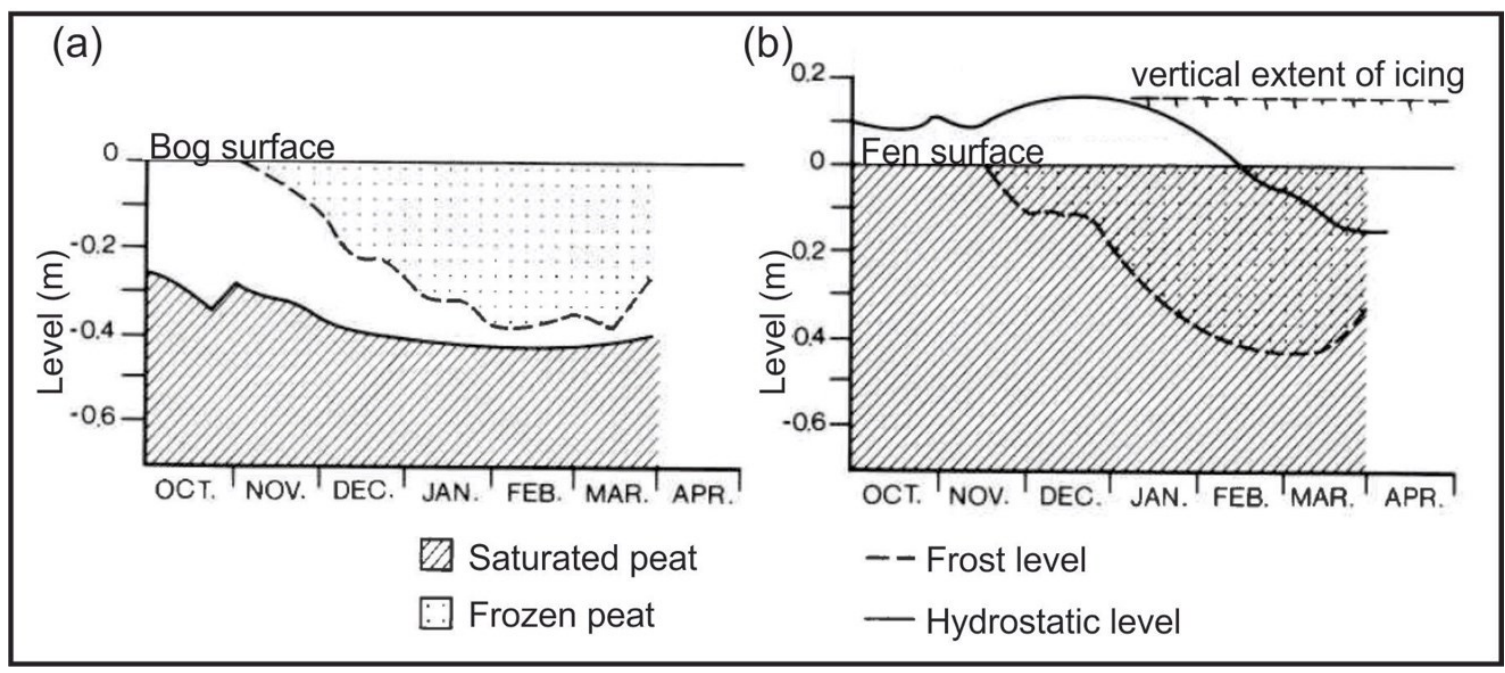

Figure 2.7 Seasonal frost and hydrostatic water level for peat in (a) bog and (b) fen in non-permafrost. Groundwater flow throughout winter maintains a high hydrostatic water level in the fen resulting in overflows and icing development (after Price and FitzGibbon 1987, Fig. 3, p. 2078). 
While seasonally thicker snowpacks have been related to less icing activity, at the event scale, snowfall has been observed to relate positively to overflows. Kane (1981) reported that an initial snowfall is required to raise the hydrostatic pressure in a stream above the ice surface for overflow to occur. He suggested that the depth of snow required for this to happen may be calculated by:

$$
h_{s}=\left(\gamma_{w}-\gamma_{i}\right) h_{i} / \gamma_{s}
$$

where $h_{s}=$ thickness of snow $(\mathrm{cm}) ; h_{i}=$ thickness of ice cover $(\mathrm{cm}) ; \gamma_{w}, \gamma_{i}, \gamma_{s}=$ specific gravity of water, ice, and snow $\left(\mathrm{g} \mathrm{cm}^{-3}\right)$, respectively. The added surcharge would cause the water under pressure to rise more than the ice thickness and spill out on the surface through fractures in the ice. Similarly, Price (1983) observed the added weight of the snowpack contributed to hydrostatic pressure. Van Everdingen (1982a) observed a link between significant snowfalls and a rapid rise in the icing level followed by a small decline as the snow settled. Therefore, the influence of snow on overflows occurs at both seasonal and event time scales.

\subsubsection{Anthropogenic causes}

Icings are a natural phenomenon but anthropogenic changes to the hydrologic and thermal regime may induce icing. Disturbance at natural shallow drainage channels by construction of infrastructure commonly involves the compaction of organic material by vehicular traffic and fill placement, which changes the albedo and snow cover leading to greater frost penetration (Sloan et al. 1976). The frost penetration or aggradation of permafrost beneath infrastructure dams water flow and causes it to flow onto the surface. Observations of icings resulting in this way have been made along the Dempster 
Highway (van Everdingen 1978, 1982b) and the Alaska Highway (Eager and Pryor 1945).

\subsection{Canadian Shield hydrology}

The Great Slave Upland region is located entirely within the low-lying terrain of the subarctic Canadian Shield. In the threshold-mediated hydrology of the northern Shield, flow generation is related to the area of the hydrologic elements (or physiographic units) that make up a catchment, and mainly consist of bedrock uplands, soil-mantled slopes, and soil-filled valleys that commonly contain wetlands or lakes (Spence and Woo 2006, Woo and Mielko 2006). Open water makes up 25\% of the Shield area (Spence and Woo 2006, 2008). The sources of water are rainfall, snowmelt, lateral inflow from upstream lakes, and runoff from bedrock uplands (Woo and Mielko 2008). Runoff may be significant due to the surface area of exposed bedrock in the region (Spence and Woo 2003). Recharge occurs in the spring and fall when the ratio of precipitation or snowmelt to evapotranspiration is high (Thorne 1992, Woo and Mielko 2008). Surface or subsurface outflow from one basin element or lake to another occurs once storage surpasses its threshold, which may be at a bedrock sill or a channel carved in the soil (Spence and Woo 2003, 2006, Woo and Mielko 2008). Flow connectivity among lakes within a drainage basin is dependent on the water balance and storage capacity of each lake and its direct catchment (Woo and Mielko 2008). Therefore, outflow is governed by (1) antecedent storage conditions, which are a product of water balance from past periods, (2) the current water balance, which is a function of precipitation, evaporation, lateral inflow from slopes and upstream lakes, and outflow, and (3) storage capacity (Figure 2.8). As a result, outflow production is variable among Shield lakes and flow 
(a)

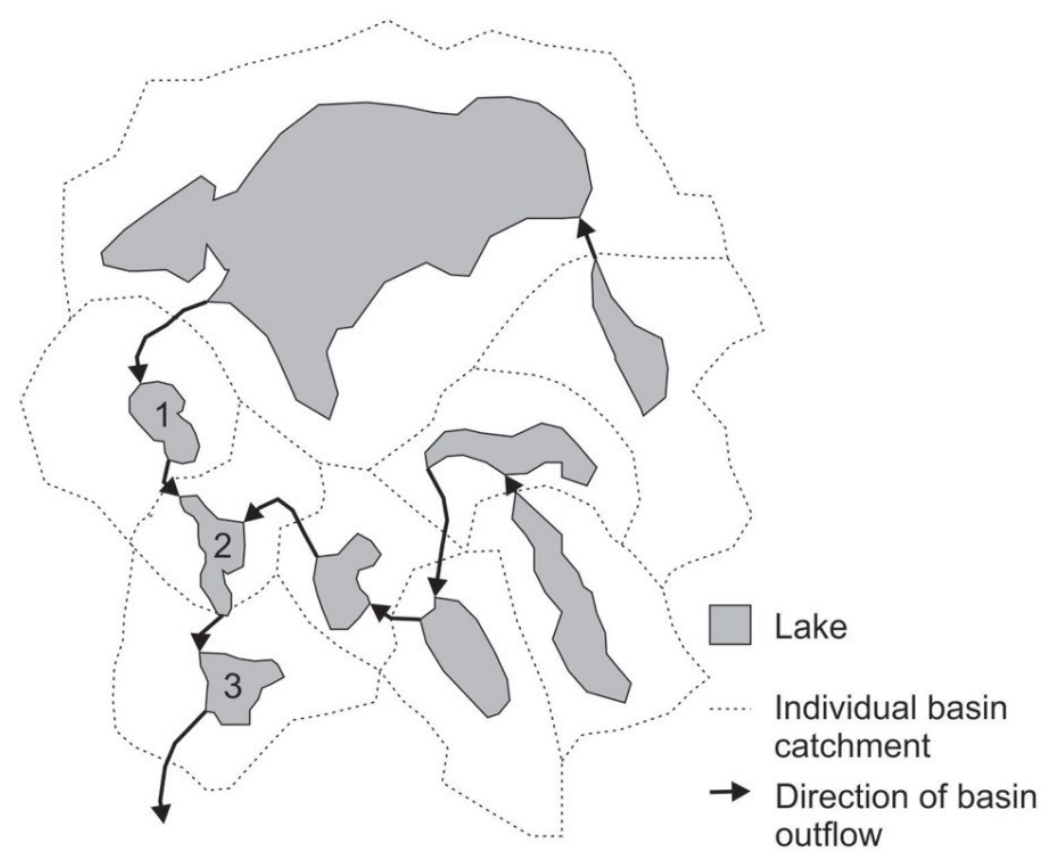

(b)
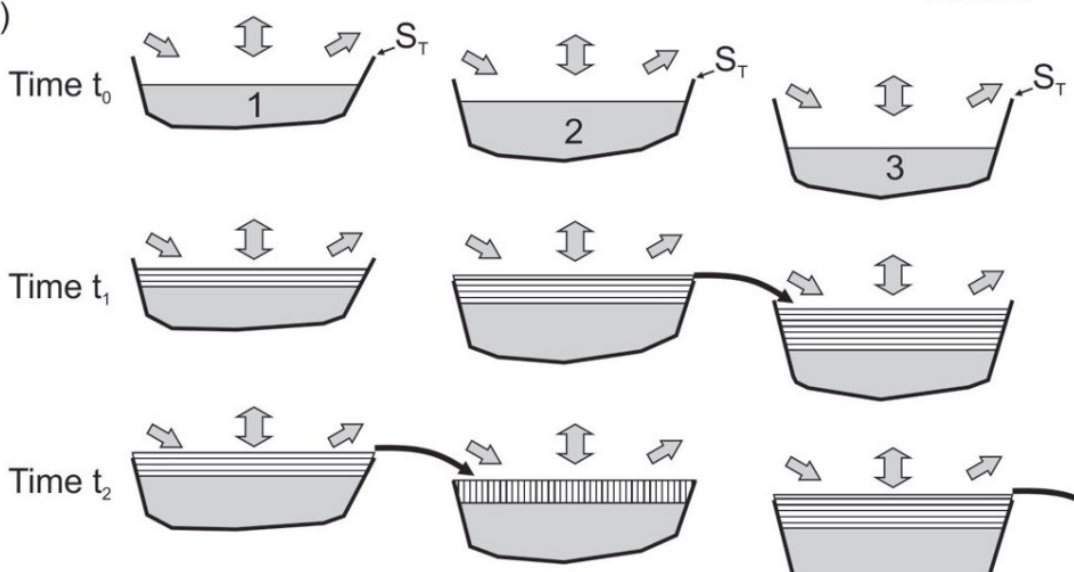

ऽ仙 Lake inputs

$$
\mathrm{S}_{\mathrm{T}} \quad \text { Storage }
$$
threshold
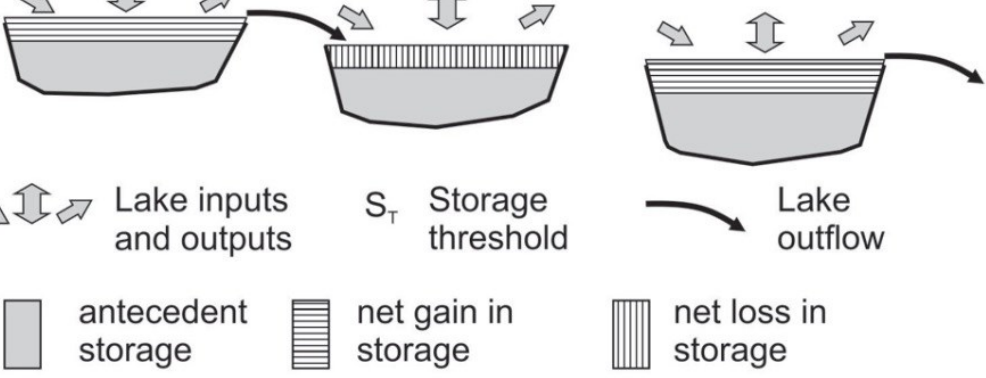

net gain in storage

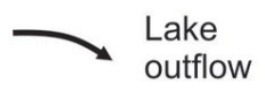

net loss in storage

Figure 2.8 (a) Schematic showing a chain of lakes within a drainage basin, lake catchment variability, and direction of basin outflow. (b) Threshold-mediated flow concept for a series of three lakes (i.e., 1, 2, and 3 in (a)) showing the intermittent flow connectivity as function of lake water inputs and outputs, antecedent storage, and net storage gain or loss over time for individual lakes. Between $t_{0}$ and $t_{1}$, all lakes have a positive water balance but only the water level in lake 2 exceeds the threshold and generates outflow. Between $t_{1}$ and $t_{2}$, the positive water balance in lakes 1 and 3 generates outflow whereas the negative water balance in lake 2 lowers the level below the threshold and outflow ceases, interrupting the continuity of flow (modified from Woo 2012, Fig. 7.38, p. 338). 
connectivity may not be continuous within a drainage basin (Spence and Woo 2006, Woo and Mielko 2007, 2008, Woo 2012). Morse and Wolfe's (2015) long-term record showed icing activity to be common in the Great Slave region, despite the low-lying relief. The relation between icings and autumn rainfall demonstrates the importance of catchment storage status and lake levels at the beginning of winter and indicates that the Canadian Shield is hydrologically active in the winter (Morse and Wolfe 2015).

\subsubsection{Wetlands}

Wetlands, defined by the abundance of water, are common in the soil-filled valleys of the Shield (Spence and Woo 2008). The main wetland type in the Great Slave Uplands is peatland, an organic wetland with more than $40 \mathrm{~cm}$ of peat (National Wetlands Working Group 1997, Ecosystem Classification Group 2008). A bryophyte and graminoid dominated peatland is classed as a bog or a fen (National Wetlands Working Group 1997). A bog may be raised or level with surrounding terrain; receives water solely through precipitation and snowmelt; and the water table is commonly at or below the surface. A fen has a fluctuating water table; ground- and surface water movement are common, making fens rich in dissolved minerals; surface flow may be through open water bodies, such as channels (National Wetlands Working Group 1997). Wetlands are common in areas with shallow depressions, low hydraulic gradients, and a shallow impermeable layer, such as permafrost (Woo 2012). Water is commonly retained in surface depressions and subsurface flow occurs through the organic matrix (Woo 2012).

Wetlands commonly contain a layer of peat at the surface. In the subarctic, this peat layer may be $2-4 \mathrm{~m}$ thick (Woo 2012). Peat commonly has two layers, a less decomposed layer near the surface called the acrotelm, and a more decomposed layer at 
depth known as the catotelm, each having very different hydrologic properties. Quinton et al. (2008) found the hydraulic conductivity in the upper $10 \mathrm{~cm}$ of peat to be about three orders of magnitude greater than in peat below $20 \mathrm{~cm}$ depth. In saturated peatlands, flow is concentrated in the upper, more porous layer and rarely penetrates the denser layer beneath (Quinton et al. 2008, Woo 2012).

Hydrologic activities have a strong seasonality, as the system commonly freezes up in the winter, except where there is a perennial spring (Woo 2012). Before the wetland has frozen back, the suprapermafrost water may be discharged onto the surface, producing an icing (Woo 2012). Price and FitzGibbon (1987) observed elevated hydrostatic pressure in a fen where the freezing front stayed in contact with the water level. This appeared to be magnified during periods of cold temperatures and with considerable snowfall. Price and FitzGibbon (1987) observed winter water levels in fens to be related to the size of the contributing area. Due to the presence of water flow, icings are associated with fens as opposed to bogs.

\subsubsection{Streamflow regime}

The Great Slave region has commonly been described has having a subarctic nival streamflow regime, where the highest flows are during the spring freshet (Church 1974, Spence et al. 2011). However, observations show that from about 1997 to 2009, there was a shift to a nival/pluvial regime as a result of increased autumn rainfall (Spence et al. 2011). This regime change is most noticeable in small subarctic Canadian Shield drainage basins (Spence et al. 2011). Observations and model results indicate that lake surface storage in the Shield provides the majority of the winter baseflow (Spence et al. 2014). Increases in autumn rainfall are linked to higher baseflows in the creeks at the 
time of freeze up (Kokelj et al. 2012). Hence, in the Canadian Shield autumn rainfall is important for water availability at the beginning of the freezing season, creating favourable conditions for icing development.

\subsection{Tibbitt to Contwoyto Winter Road}

The Tibbitt to Contwoyto Winter Road (TCWR) developed from an earlier winter road built in the 1960s to access the Tundra Mine near Courageous Lake, NU, which is now closed (EBA 2002). The road was extended in the 1970s to service the Lupin Gold Mine on Contwoyto Lake. More recently, the road has been servicing the region's diamond mines at Lac de Gras (Ekati and Diavik), Snap Lake (closed in 2015), and Gahcho Kué (Figure 1.1).

The seasonal road begins about $60 \mathrm{~km}$ east of Yellowknife and is built each winter, extending 400 to $600 \mathrm{~km}$ north to Contwoyto Lake, depending on mining activities (Nuna Logistics 2017). Most of the road (85-87\%) is built on lake ice, while the remainder consists of 64 portages (Joint Venture 2016).

Construction of the winter road begins in late December, once the ground freezeback has reached about $30 \mathrm{~cm}$ and the lake-ice thickness is $40 \mathrm{~cm}$, the latter being the limiting factor (C. Ambrose, pers. comm. 2012). Snow is cleared from the portages, which are then flooded to promote ice growth and accommodate the heavy traffic loads (C. Ambrose, pers. comm. 2012). The winter road typically opens between the end of January and beginning of February and operates for 8-10 weeks (Joint Venture 2016).

The TCWR is essential for mine re-supply, with the number of northbound loads per year ranging from 3,500 to 10,900 (S.A. Wolfe, pers. comm. 2015). The range in 
loads is a function of what comes first: meeting targeted numbers or the end of the operating season. The length of the operating season depends on winter conditions and has ranged from 33 to 80 days between 2000 and 2014 (S.A. Wolfe, pers. comm. 2015, Joint Venture 2016). The road is also used to supply exploration and outfitting camps, and by local people and tourists. The main overland problem faced by the TCWR operators is overflow at several portages (T. Tattrie, pers. comm. 2012). This thesis examines overflow at these portages.

\subsection{Summary}

Icings result from a seasonal hydrologic process that occurs in northern regions during winter. The occurrence of icings has been linked to rainfall, snowfall, air temperature, active-layer freezeback, and anthropogenic causes. Freezeback of the active layer restricts water flow by reducing the cross-sectional area of the unfrozen portion of the active layer and causing an increase in the hydraulic potential. The timing and rate of active-layer freezeback are controlled by air temperature, snowpack, moisture content, and soil thermal and physical properties. Autumn rainfall is important for water availability at the start of the freezeback season especially in the subarctic Canadian Shield. Flow connectivity between chains of lakes or valley segments within a drainage basin is subject to the catchment size and antecedent conditions of each basin and may not be continuous. 


\section{Chapter: STUDY AREA AND METHODOLOGY}

\subsection{Introduction}

The study sites discussed in this thesis are located at portages 11,16 , and 23 on the TCWR (Figure 1.1). This chapter describes the location, physiography, and climate of the region, and the characteristics of the study sites. The methods used to select the study sites, collect and analyze data on groundwater overflows, air and ground temperatures, snow accumulation, and winter road practices are explained.

\subsection{Study area}

The study area was approximately $120 \mathrm{~km}$ north - northeast of Yellowknife, along the TCWR. Portages 11 and 16 are south of Gordon Lake and portage 23 is north of Gordon Lake. The overall study area is bounded by $62.77^{\circ} \mathrm{N}, 63.34^{\circ} \mathrm{N}, 113.03^{\circ} \mathrm{W}$, and $113.27^{\circ} \mathrm{W}$ (Figure 1.1).

\subsubsection{Regional setting}

The study area lies within the Great Slave Upland High Boreal (UHB) and Great Slave Upland Low Subarctic (ULS) ecoregions of the Taiga Shield (Ecosystem Classification Group 2008). The UHB and ULS are underlain by the Slave Geological Province, an Archean craton of the Canadian Shield, trending southwest - northeast from Great Slave Lake to Coronation Gulf. The craton is composed of $65 \%$ granitoid, $24 \%$ metasedimentary, and $9 \%$ metavolcanic rocks, and covers an area of approximately $213,000 \mathrm{~km}^{2}$ (Padgham and Fyson 1992). The metasedimentary rocks host gold deposits while the diamond-bearing kimberlite pipes that intruded the craton 45 to 75 million years ago are the focus of current industrial interest (Kerr et al. 1997, Nowicki et al. 2004). 
The area was glaciated until about 9000 years ago by the Laurentide Ice Sheet (Dyke et al. 2003). The ice-scoured, southwest-sloping terrain is dominated by gently undulating to moderately rugged exposed bedrock (Ecosystem Classification Group 2008). Bouldery till veneers and blankets are the dominant unconsolidated material in the study region (Stevens et al. 2013, Olthof et al. 2014). Till blankets are mainly found in topographic depressions between bedrock highs. Sandy to gravelly outwash deposits are present in the north and east of the study region. Organic deposits are common but limited in extent, with fens and bogs occurring in low-lying areas (Ecosystem Classification Group 2008, Stevens et al. 2013). The region contains lakes of varying size with the main rivers, including Yellowknife River and Cameron River, draining into Great Slave Lake (Kokelj 2003, Ecosystem Classification Group 2008).

The UHB and ULS are located south of the treeline with forest vegetation dominated by black spruce (Picea mariana), paper birch (Betula papyrifera), jack pine (Pinus banksiana), and dwarf birch (Betula pumila) (Ecosystem Classification Group 2008, Stevens et al. 2013, Olthof et al. 2014). Sphagnum spp. and sedges (Carex) dominate the wetlands.

Permafrost is widespread but discontinuous (Heginbottom et al. 1995). The perennially frozen ground is up to $50 \mathrm{~m}$ thick beneath peatlands but is absent from exposed bedrock in the Yellowknife area (Brown 1973, Wolfe et al. 1998). Reported mean annual temperatures range from -0.1 to $-2.9^{\circ} \mathrm{C}$ near the top of permafrost and -0.02 to $-1.4{ }^{\circ} \mathrm{C}$ at the depth of zero annual amplitude, depending on organic cover and surface conditions (Brown 1960, Karunaratne et al. 2008, Karunaratne 2011, Morse et al. 2015). Active-layer thickness ranges from 0.3 to $1.2 \mathrm{~m}$ (Brown 1973, Karunaratne 2011). 
Icing activity is common in Great Slave Uplands (GSU). UHB has the highest number of icings and total return frequency (up to 88\%) of the GSU ecoregions (Morse and Wolfe 2015). ULS has less icings than UHB but they are the most active and densely distributed icings in the GSU (Morse and Wolfe 2015).

\subsubsection{Climate}

The Great Slave Upland region has a subarctic continental climate, due to its latitude, distance from the ocean, and the influence of the Western Cordilleran mountain barrier on North America's climate; winters are long and summers are short (Burn 2012). The closest weather station to the study area is 70 to $120 \mathrm{~km}$ away at the Yellowknife Airport. The mean annual air temperature for Yellowknife is $-4.3^{\circ} \mathrm{C}$, with mean monthly temperatures ranging from $17.0^{\circ} \mathrm{C}$ in July to $-25.6{ }^{\circ} \mathrm{C}$ in January (Figure 3.1 ) (data for 1981-2010, Environment Canada 2016). The freezing season, defined from the first day that daily mean air temperature remains below $0{ }^{\circ} \mathrm{C}$, typically starts in mid-October and lasts until May.

The mean total annual precipitation is $289 \mathrm{~mm}, 55 \%$ of which falls as snow (Environment Canada 2016, see Figure 3.1). Based on monthly precipitation, the driest period of the year is January through April when average monthly precipitation is $13 \mathrm{~mm}$. The wettest period is from July to September with average monthly precipitation of 39 mm. Snow accumulation typically commences in mid-October and it remains on the ground until April. The maximum snow depth at month end occurs in February and is, on average, $38 \mathrm{~cm}$. 


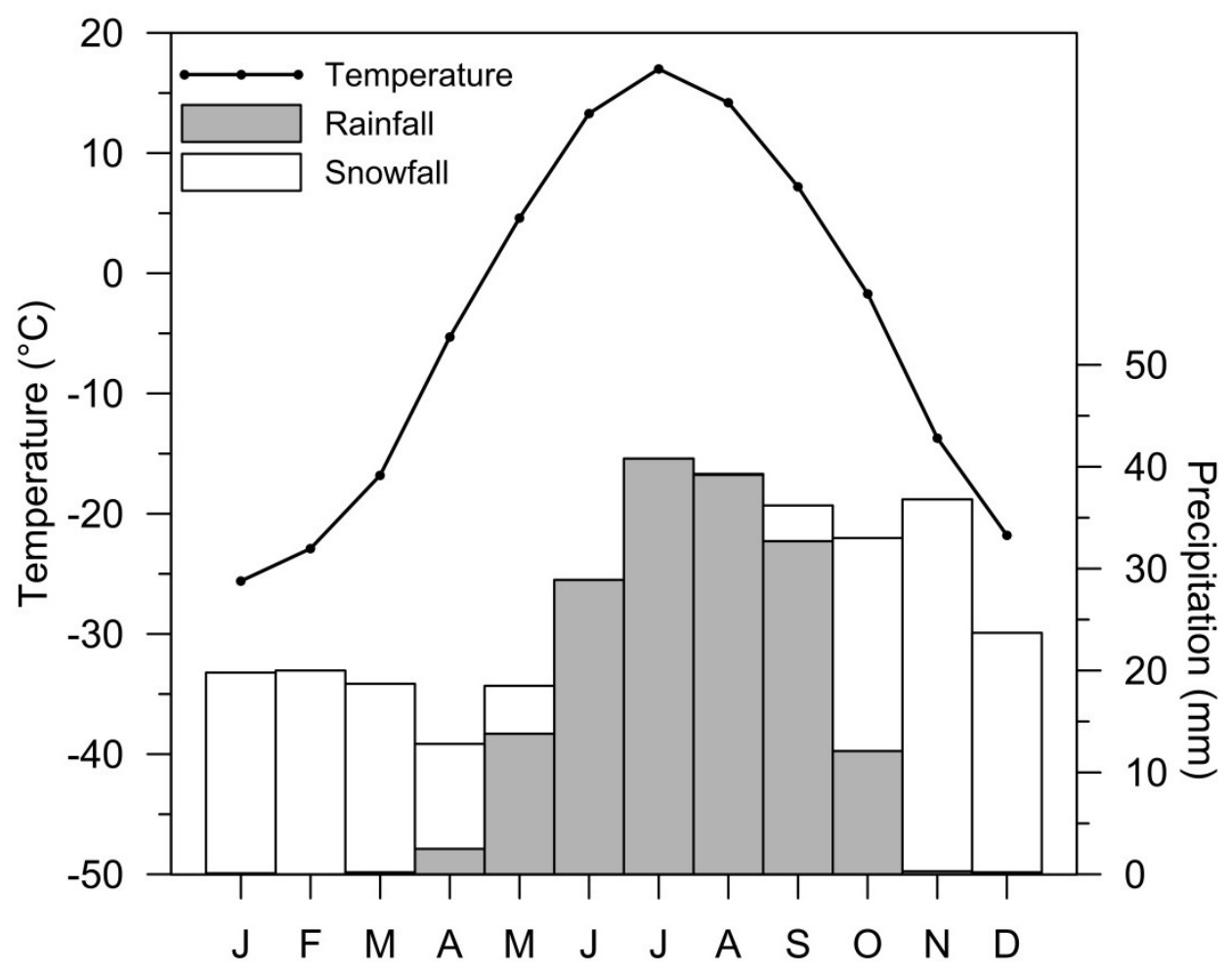

Figure 3.1 Mean monthly air temperature and total monthly precipitation, divided between rainfall and snowfall (in snow water equivalent), for 1981-2010 at Yellowknife Airport (Environment Canada 2016). 


\subsection{Site selection}

Study site selection was based on two main criteria: first, known overflow activity, and second, accessibility. These criteria were aimed at increasing the likelihood of observing overflows during the two-year study, and enabling access to the sites from Yellowknife on a seasonal basis. In addition, sites had to be open enough for a helicopter to land there.

As a result, the study sites were chosen within $125 \mathrm{~km}$ of Yellowknife. Sites with a known history of icing occurrence were determined through discussions with the TCWR maintenance contractor, Nuna Logistics Ltd., and the Indigenous and Northern Affairs Canada (INAC) resource officer. Three sites, P11, P16, and P23 were selected (Figure 1.1). In addition, a fourth site, located on portage 16 where no overflows were known to have occurred, was selected as a control site to examine non-icing ground thermal conditions.

\subsection{Portage descriptions}

\subsubsection{Portage 11}

Portage 11 was the southernmost of the study sites, at kilometre 32 on the TCWR (Figure 1.1). The $1.8 \mathrm{~km}$-long portage crosses through an area of coniferous woodland, bedrock and boulder fields, fens, and bogs (EBA 2002). The portage route follows the soil-filled, fen-dominated valley from Dome Lake at $256 \mathrm{~m}$ a.s.1. to Lake P11-1 at $277 \mathrm{~m}$ a.s.l. The valley, which ranges in width from approximately 20 to $100 \mathrm{~m}$, is constrained by bedrock uplands. The bedrock uplands reach elevations of $290 \mathrm{~m}$ a.s.l. within 150 to $250 \mathrm{~m}$ of the road. The overall gradient of the valley is southward to Dome Lake. 
The instrumentation site was located on the southern portion of the portage, approximately $360 \mathrm{~m}$ from Dome Lake (Figure 3.2), where the portage is oriented east west. The site was downstream from the confluence of two valleys, each running from a water body. The valley to the west contains the current TCWR route. It is approximately $720 \mathrm{~m}$ from a pond down an average gradient of $1^{\circ}$ to the monitoring site. The valley to the northwest, which contained a previous alignment, starts $770 \mathrm{~m}$ from the site at Lake P11 (elevation $272 \mathrm{~m}$ a.s.1.) and has an average gradient of $0.7^{\circ}$. The monitoring site was at $261 \mathrm{~m}$ a.s.l. The valley was about 40 to $45 \mathrm{~m}$ wide at the instrumentation site; local bedrock uplands reaching elevations of 275 to $280 \mathrm{~m}$ a.s.l. were north and south of the right-of-way, respectively.

The area upstream of the monitoring site and north of the winter road alignment was very wet with water at or above the surface (see Figure 3.2 (a)). The water depth reached up to $95 \mathrm{~cm}$ (see Figure 3.2 (b)). The soil stratigraphy comprised approximately $30 \mathrm{~cm}$ of sphagnum-covered peat over saturated fine sand. The vegetation was dominated by graminoids and horsetail (Equisetum spp.) in the wet area and shrubs (willow (Salix spp.) and birch (Betula glandulosa)) and sphagnum moss in the drier areas toward the bedrock uplands to the north. Along the road alignment and south of the alignment the ground surface was hummocky with water in the depressions. The ROW was slightly raised relative to the surrounding ground surface due to the accumulation of $40 \mathrm{~cm}$ of sandy gravel road aggregate. The sandy gravel overlay $48 \mathrm{~cm}$ of saturated peat which overlay silty sand with ice lenses up to $2 \mathrm{~mm}$ thick below the frost table. The vegetation on the road was dominantly graminoids ranging in height from 30 to $60 \mathrm{~cm}$. 

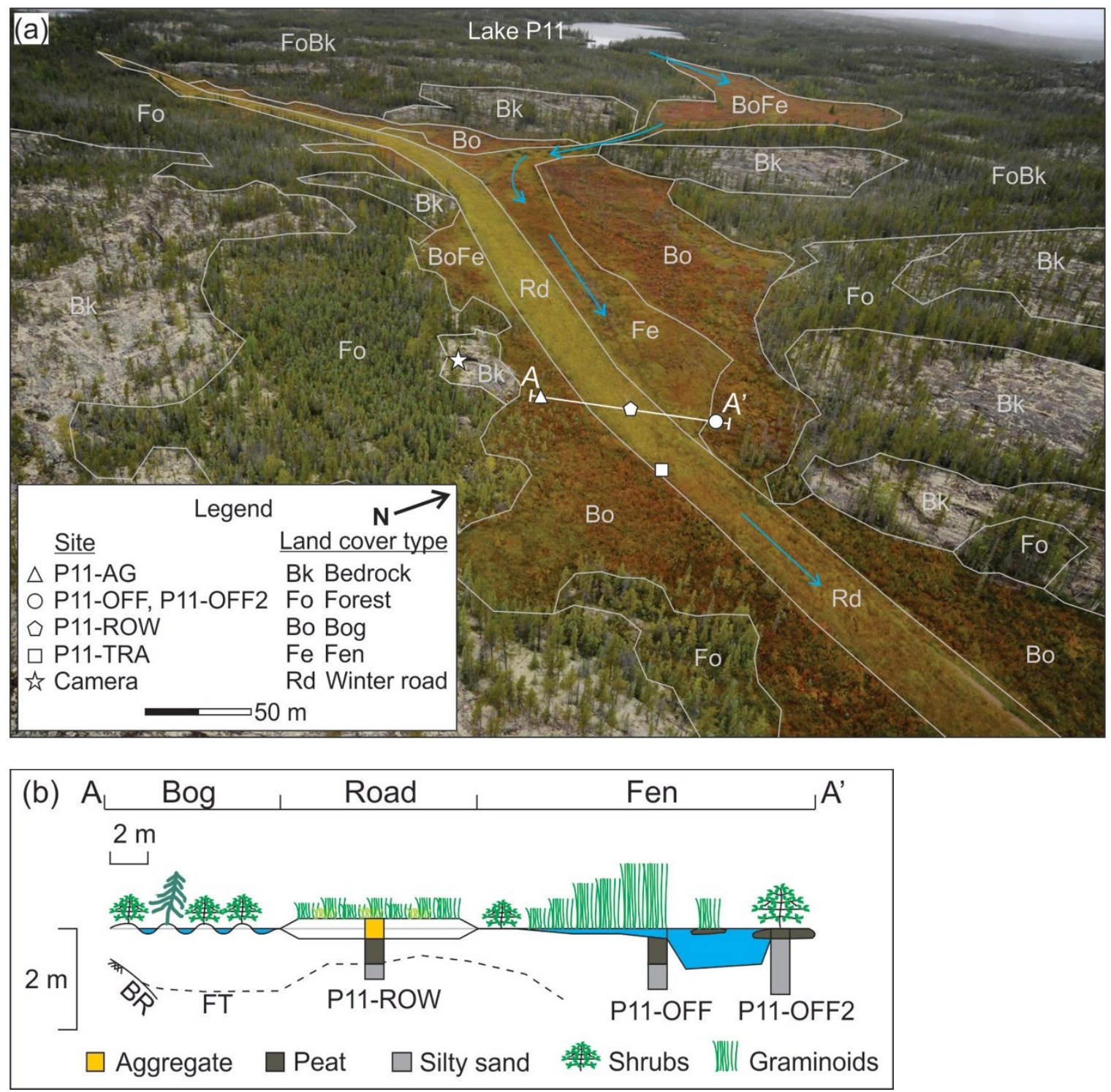

Figure 3.2 (a) Aerial view of P11 showing location of instrumentation and distribution of land cover type. Blue arrows indicate direction of water flow. (b) Cross-section of A-A' at P11 monitoring site. The bedrock (BR) and frost table (FT) were determined by probing and hand augering in September 2012. Photo taken by W. Sladen, September 2012. 
South of the road, the vegetation cover comprised willow and birch shrubs, moss, blueberry (Vacccinum spp.), sedge, horsetail, and a few black spruce trees.

The active-layer thickness ranged from $120 \mathrm{~cm}$ south of the alignment to 66 to 89 $\mathrm{cm}$ beneath the winter road ROW, to greater than $130 \mathrm{~cm}$ in the wet area north of the winter road. Immediately east of the monitoring site, where the valley narrowed considerably due to the bedrock uplands (Figure 3.2), bedrock was on average $46 \mathrm{~cm}$ beneath the surface; where bedrock was not encountered, the active layer was about 110 $\mathrm{cm}$ thick. In this narrow portion of the valley, the shallow bedrock and top of permafrost may act as a barrier to water flow, referred to as a bedrock sill in the threshold-mediated "fill-and-spill" drainage concept (Spence and Woo 2003, 2006).

P11 has a history of water flowing onto the road during the TCWR operating season (C. Ambrose, pers. comm. 2012). Water typically appears on the north side of the road (A. Blum, pers. comm. 2014). However, in 2011/12, a particularly bad year for water problems at P11, water appeared on the south side of the road as well (A. Blum, pers. comm. 2014). In February 2012, a four to five-foot icing blister formed, which burst and flowed towards Dome Lake. As a result, an embankment, approximately $1 \mathrm{~m}$ high of blast rock overlain with sand was constructed over this section of portage 11 in March 2013. In July 2014, the site was burned by wild fire, which further modified site conditions from those present when the instrumentation was installed in September 2012.

\subsubsection{Portage 16}

Portage 16 is located south of Gordon Lake (Figure 1.1). In 2012-14, most of the vegetation near the $2.7 \mathrm{~km}$-long portage was recovering from wild fire that burned in 
1998 (GNWT 2011). The remainder of the portage was made up of bedrock and boulder fields, water, and fens (EBA 2002). The southern end of the portage starts at Lake P15-1 (298 $\mathrm{m}$ a.s.1.) and the north end is at Lee Lake (292 $\mathrm{m}$ a.s.1.). The portage route is fairly level, reaching a maximum elevation at $300 \mathrm{~m}$ a.s.l. two thirds of the way north. The valley is broader than at P11, reaching widths of over $300 \mathrm{~m}$, and was dominated by burned peatland. Isolated fen areas were present at the south end and mid-way along the portage. The bedrock uplands reach elevations of $326 \mathrm{~m}$ a.s.l. within $220 \mathrm{~m}$ of the road. Two sites were chosen for instrumentation on portage 16 , one along the southern portion of the portage, P16S, and one mid-way, P16N.

\subsubsection{Portage 16 south}

Portage 16 south (P16S), located at kilometre 46 on the TCWR, was chosen as a dry control site (Figure 3.3). It had no known history of water problems. The portage route is oriented east - west at the instrumentation location, traversing a well-drained bog. The surface of the portage route consisted mainly of sandy gravel aggregate with exposed peat in places and was sparsely vegetated with grasses. The bog north of the winter road was hummocky and well drained. The vegetation consisted mainly of Labrador tea (Rhododendron groelandicum), ranging in height from 25 to $60 \mathrm{~cm}$, lichen (Cladina), mosses, and the occasional spruce tree. South of the winter road was an isolated stand of spruce and paper birch that did not show signs of being burned in the 1998 wild fire. The site was at 296 m a.s.1. with a very gentle slope southwest towards Lake P16-1.

The stratigraphy consisted of damp, fibrous peat to depths of $140 \mathrm{~cm}$. Below the frost table, the peat contained visible ice crystals. On ROW, there was a $20 \mathrm{~cm}$-thick layer of sand and gravel road aggregate. Bedrock was not encountered during drilling. 

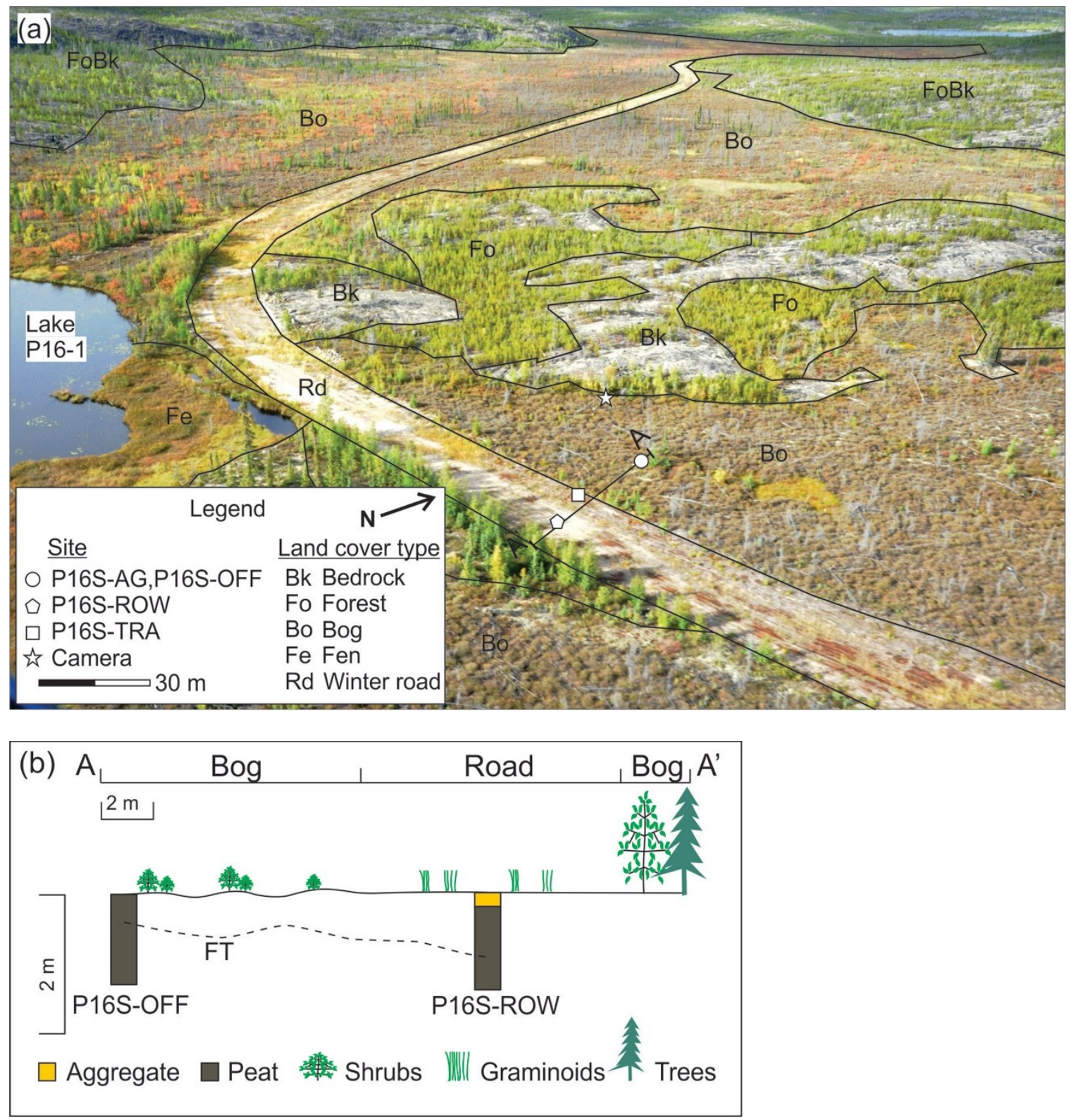

Figure 3.3 (a) Aerial view of $\mathrm{P} 16 \mathrm{~S}$ showing location of instrumentation and distribution of land cover type. The area was burned by a wild fire in 1998. The bog in the bottom portion of the image slopes very gently towards Lake P16-1. (b) Cross-section of A-A' at P16S monitoring site. The frost table (FT) was determined by probing and hand augering in September 2012. Photo taken by W. Sladen, September 2012. 
The active layer beneath the road ranged from 65 to $88 \mathrm{~cm}$, whereas beneath natural ground the active layer was thinner, ranging from 43 to $63 \mathrm{~cm}$.

\subsubsection{Portage 16 north}

Portage 16 north $(\mathrm{P} 16 \mathrm{~N})$ was located mid-way along portage 16 at kilometre 47 on the TCWR (Figure 3.4). At this location, the portage route is oriented east - west at $296 \mathrm{~m}$ a.s.l. The site was located downslope of two creeks which drain southeast toward Lake P16-2. The lakes from which these watercourses run were $610 \mathrm{~m}$ and $1750 \mathrm{~m}$ to the north and northwest, respectively, with overall gradients of approximately $0.6^{\circ}$. As a result, the ROW had flowing water at or up to $15 \mathrm{~cm}$ above the ground surface, and the vegetation was dominated by graminoids up to $130 \mathrm{~cm}$ tall. To the north and south of the ROW, the ground was drier. Vegetation south of the ROW was mainly mosses, grasses up to $70 \mathrm{~cm}$ tall, and birch and willow shrubs up to $180 \mathrm{~cm}$ in height. North of the ROW, the vegetation was mostly moss, 40 to $60 \mathrm{~cm}$-tall graminoids, and spruce up to $110 \mathrm{~cm}$ in height. There were some birch and willow shrubs, and jack pine up to $160 \mathrm{~cm}$ in height. There was an area of peat mounds with exposed peat at the surface and sparsely vegetated with spruce trees about $100 \mathrm{~cm}$ tall north of the ROW.

The stratigraphy beneath the right of way consisted of $80 \mathrm{~cm}$ of saturated peat overlying $20 \mathrm{~cm}$ of saturated silty sand, overlying clayey silt containing $10 \%$ visible ice to $120 \mathrm{~cm}$ depth. Off ROW, the stratigraphy consisted of damp peat to $120 \mathrm{~cm}$ depth.

The active-layer thickness ranged from 67 to $107 \mathrm{~cm}$. The active layer was the thinnest $(67-71 \mathrm{~cm})$ at the drier edges of the ROW and thickest on ROW where the surface water was at its deepest $(91 \mathrm{~cm})$ and off ROW near P16N-AG $(107 \mathrm{~cm})$. 

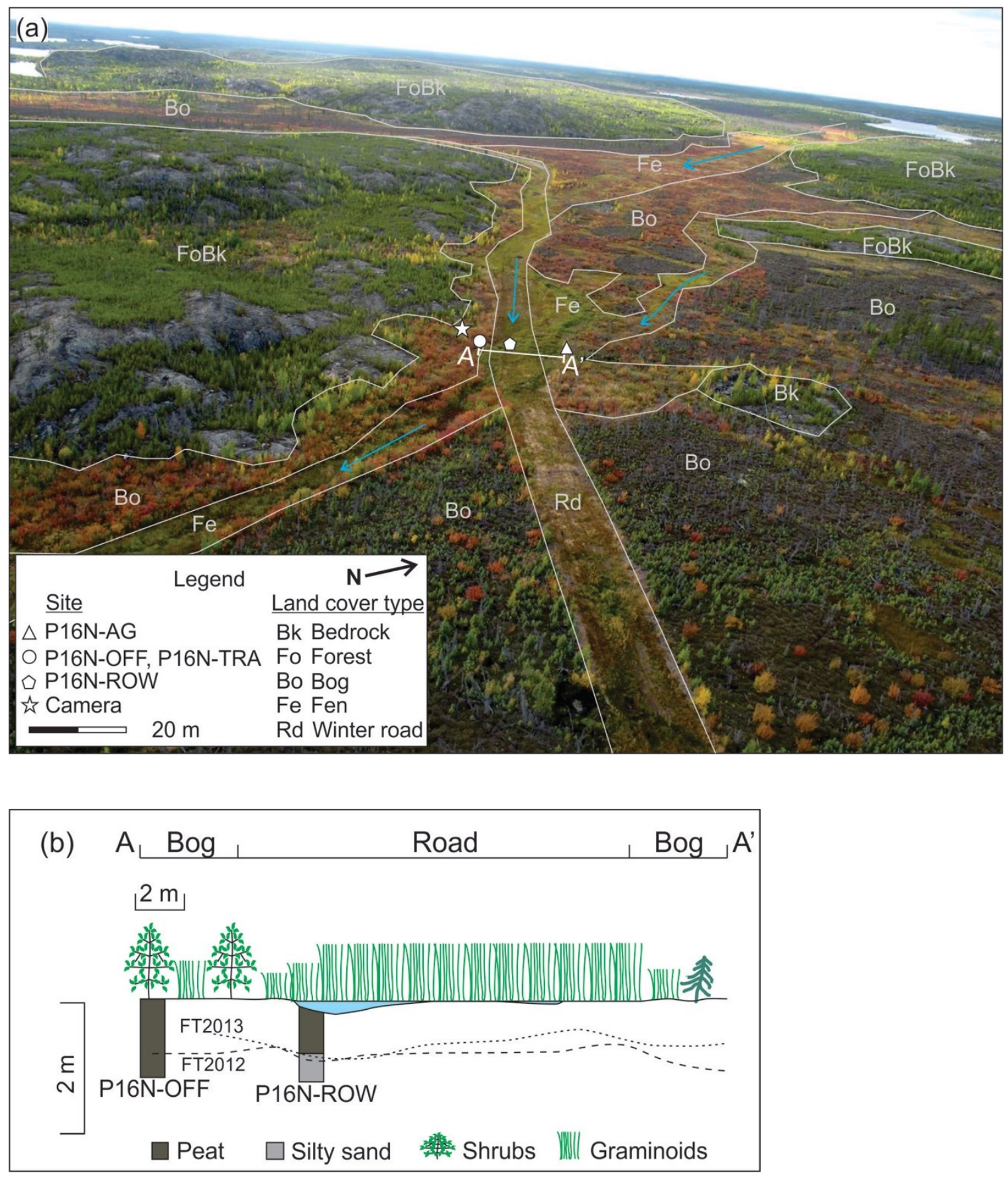

Figure 3.4 (a) Aerial view of P16N showing location of instrumentation and distribution of land cover type. Blue arrows indicate direction of water flow. The area was recovering from a 1998 wild fire. (b) Cross-section of A-A' at P16N monitoring site. The frost table (FT) is shown for September 2012 and 2013. Photo taken by W. Sladen, September 2013. 


\subsubsection{Portage 23}

Located north of Gordon Lake at TCWR $\mathrm{km} \mathrm{58,} \mathrm{portage} 23$ was the northernmost study site. Portage 23 is $3.2 \mathrm{~km}$ long and follows interconnected valleys and traverses several ponds (Figure 3.5). The upland areas were dominated with mixed and deciduous forest and the lowland portions contained fens and bogs (EBA 2002). The south end of the portage is at $355 \mathrm{~m}$ a.s.l. and the north end is at $381 \mathrm{~m}$ a.s.l. The surrounding bedrock uplands reach $393 \mathrm{~m}$ a.s.l. within $155 \mathrm{~m}$ of the road.

The instrumentation site was at the northern end of the portage, $500 \mathrm{~m}$ south of Card's Lake, at $369 \mathrm{~m}$ a.s.1. The portage route at this location is oriented north - south. The site was $225 \mathrm{~m}$ downstream from Lake P23 (371 $\mathrm{m}$ a.s.1.) (Figure 3.5). Water flows from Lake P23 towards the portage route, crosses it near the instrumentation site and then continues to flow along the west side of the alignment to Lake P23-3 (also known as Wolf Lake). The overall gradient from Lake P23 to the site is $0.5^{\circ}$. This portion of the portage was characterized by fen, bog, and a defined watercourse. The stream bed was bouldery in places. The width of the fen at the instrumentation site was about $40 \mathrm{~m}$ and was bounded to the east by bedrock upland and to the west by raised bog that extended about $70 \mathrm{~m}$ westwards to bedrock upland (Figure 3.5).

The soil stratigraphy at the site consisted of peat over bedrock. On the ROW, 112 $\mathrm{cm}$ of peat was encountered before bedrock. The water table was at $20 \mathrm{~cm}$ depth. Off ROW to the east, the frost table was at $51 \mathrm{~cm}$ and bedrock was encountered at $105 \mathrm{~cm}$ depth. The peat was saturated above and below the frost table. To the west of the ROW, beneath the raised bog frozen peat underlay $50 \mathrm{~cm}$ of unfrozen peat to $130 \mathrm{~cm}$ depth (end of borehole). 

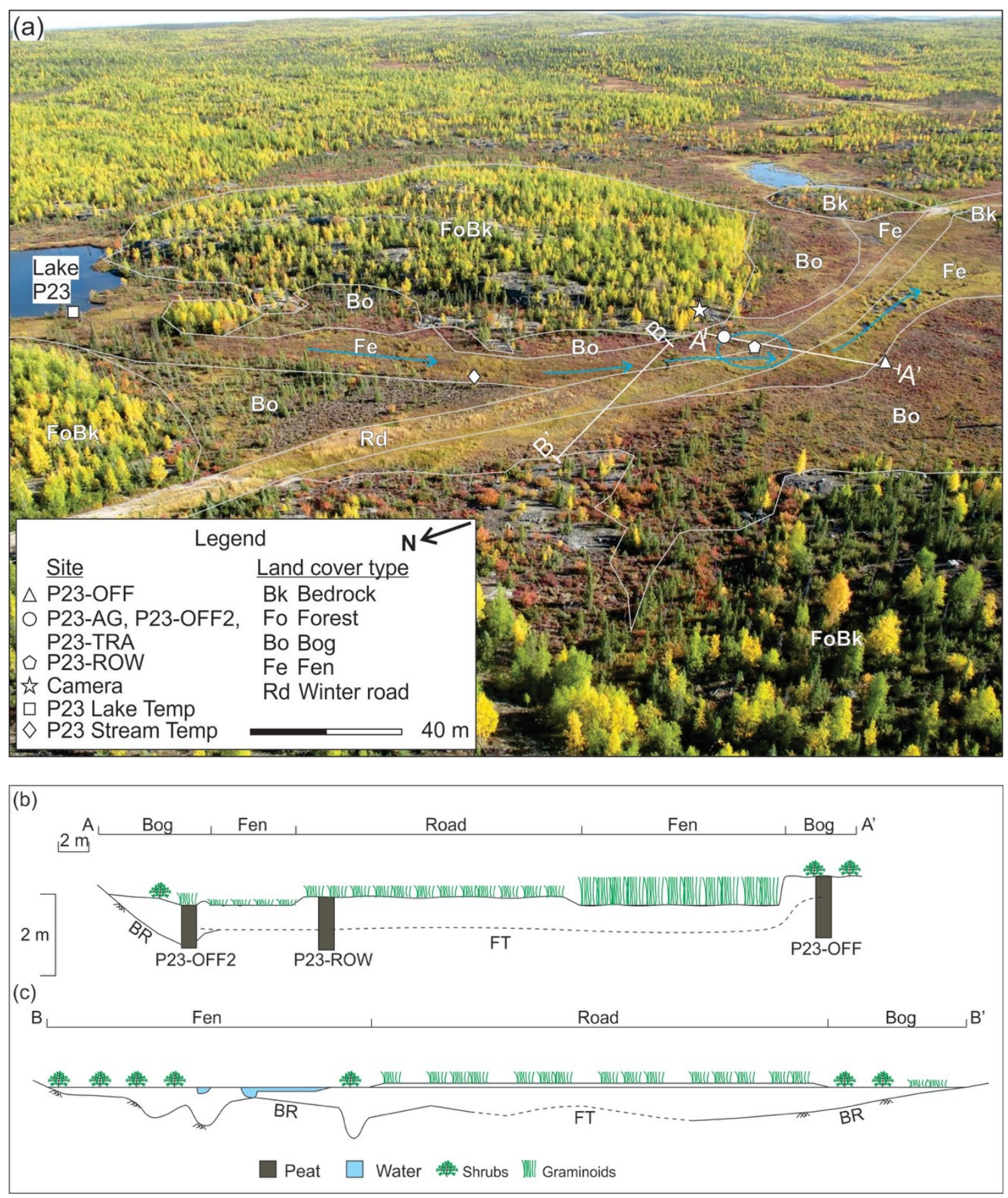

Figure 3.5 (a) Aerial view of P23 showing location of instrumentation and distribution of land cover type. Blue arrows indicate direction of water flow. The blue oval marks location of overflow observed during the study period. (b) Cross-section A-A' at P23 monitoring site and (c) cross-section B-B', north of A-A'. The depth to bedrock (BR) and frost table (FT) were determined by probing and hand augering in September 2012 (b) and 2013 (c). Photo taken by W. Sladen, September 2013. 
The east side of the ROW was vegetated with mosses, graminoids up to $25 \mathrm{~cm}$ tall, blueberry and willow shrubs. The surface of the ROW consisted of a scattering of aggregate and exposed peat and was mainly vegetated with graminoids to $40 \mathrm{~cm}$ in height. The bog, which had been burned in the past (date unknown), was hummocky with mosses, lichen, sedges, blueberry, willow and birch shrubs, ranging in height from 10 to $40 \mathrm{~cm}$, making up the dominant vegetation. A few spruce trees, 40 to $200 \mathrm{~cm}$ in height, were also present. The bedrock upland was densely vegetated with spruce, birch, and lichen.

The active-layer thickness beneath the road ranged from 47 to $74 \mathrm{~cm}$. On the raised bog the active-layer thickness was $50 \mathrm{~cm}$. East of the ROW, the frost table was at 54 to $61 \mathrm{~cm}$ depth and bedrock was encountered at depths of 48 to $77 \mathrm{~cm}$. The bedrock profile east of the ROW ranged from 15 to $125 \mathrm{~cm}$ depth and appeared to consist of several troughs (Figure 3.5 (c)). The depth of the stream flowing to the east of the ROW ranged from about 8 to $26 \mathrm{~cm}$. Upstream of the site, towards Lake P23, the area had water up to $82 \mathrm{~cm}$ deep. The frost table $(51-72 \mathrm{~cm})$ was only encountered on drier ground, where the soil-filled valley was in contact with the bedrock uplands. In the central portion, bedrock was encountered at depths of 82 to $144 \mathrm{~cm}$ (the limit of the probe).

Portage 23 has a history of water flowing onto and along the road during the operating season (C. Ambrose, pers. comm. 2012). The chain of lakes upstream of P23 has been observed to be hydrologically connected during the TCWR operating season (A. Blum, pers. comm. 2014). The current method used to control the water flow at P23 is to 
compact the snow to enhance freezing at the outlets of the two lakes upstream of Lake P23.

\subsection{Field methods}

Field work was carried out in September 2012 and 2013 and in February 2013 and 2014 to investigate the potential factors controlling icings along the TCWR.

\subsubsection{Time-lapse photography}

Time-lapse photography was used to observe the timing and rate of icing development, snow accumulation, and snow clearing and flooding of the TCWR. Time-lapse photography has been successfully used to document the build-up and decay of icings and frost mounds (van Everdingen and Banner 1979, van Everdingen 1982a). Reconyx PC800 Hyperfire Professional cameras (Reconyx, Holmen, WI) were used based on their ability to operate over a temperature range of -40 to $60^{\circ} \mathrm{C}$, take photos in low light, and the long battery life.

One or two cameras were installed at each site with a view of the anticipated area of overflow (Figure 3.6). In addition, a snow stake was placed in the field of view to document development of the snow pack. Snow depth was determined at a resolution of $2 \mathrm{~cm}$. The cameras were programmed to take pictures every hour between 13:00 and 16:00 in winter 2012/13 and between 08:00 and 20:00 in winter 2013/14. The images, which ranged in size from 150 to $680 \mathrm{~KB}$, were stored on secure digital (SD) cards with 4 or 8 GB capacity. The images were downloaded from the SD cards each summer when the cameras were collected. 


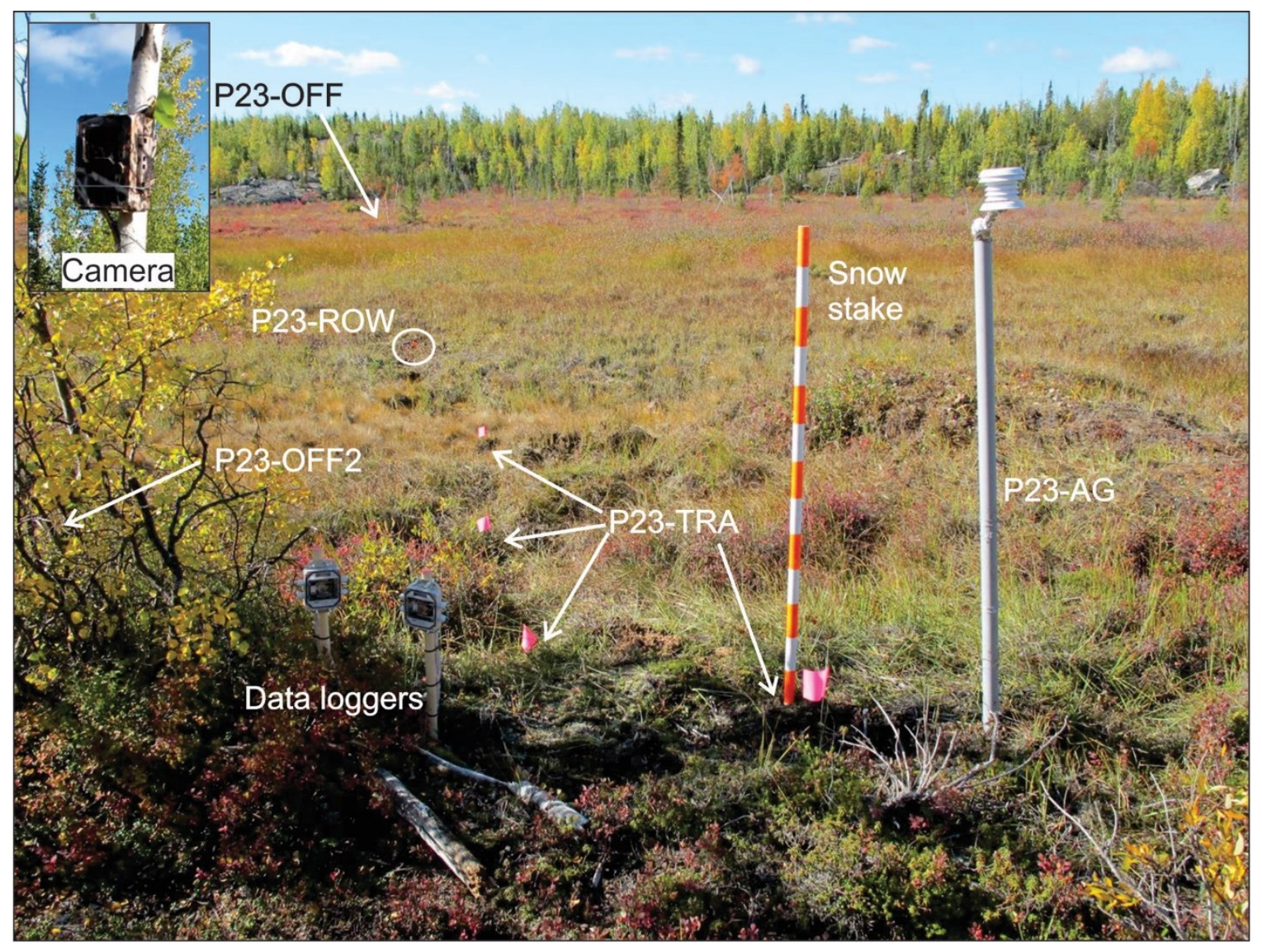

Figure 3.6 Instrumentation at P23. Image taken looking west across the winter road ROW. Vertical thermistor strings are located on ROW at P23-ROW and off ROW at P23-OFF and P23-OFF2 (located off image left behind the birch shrub). The four pink flags represent the location of each sensor (30 cm depth) in the horizontal transect (P23TRA). The air temperature sensor is located in the radiation shield and the ground surface temperature sensor is $2 \mathrm{~cm}$ beneath the ground surface at the base of the air temperature pole (P23-AG). The inset shows the wildlife camera used for the time-lapse photography. Photos taken by W. Sladen, September 2012. 
This method of observation was normally very effective, but problems occurred because of four factors (1) camera angle - a high tilt resulted in the bottom of the stake not being visible and the lens became covered with snow for extended periods; (2) camera orientation - south-facing incurred glare from the sun; (3) vegetation and snow on vegetation obscured the view of the base of the stake; and (4) wildlife knocked over the stake. Table 3.1 summarizes the availability of usable images.

\subsubsection{Air and near-surface ground temperature}

Air temperatures were recorded to determine the start and duration of the freezing season, temperature fluctuations, and to evaluate the regional variability in meteorological conditions. To remove the influence of the buffer layer, near-surface ground temperatures were measured to determine the timing and rate of freezeback. Onset HOBO Pro v2 data loggers (Onset Computer Corporation, Bourne, MA), equipped with two sensors: one internal and one external, were installed at each site to record air and near-surface ground temperatures. The external sensor was installed within a radiation shield and mounted approximately $150 \mathrm{~cm}$ above the ground surface to record air temperature (Figure 3.6). The logger, with its internal sensor, was placed $2-5 \mathrm{~cm}$ below the ground surface to record near-surface ground temperatures. The accuracy of the sensor ranged from $\pm 0.38{ }^{\circ} \mathrm{C}$ at $-20{ }^{\circ} \mathrm{C}$ to $\pm 0.2{ }^{\circ} \mathrm{C}$ at $0{ }^{\circ} \mathrm{C}$ and above. The resolution ranged from $\pm 0.05{ }^{\circ} \mathrm{C}$ at $-20{ }^{\circ} \mathrm{C}$ to $\pm 0.02{ }^{\circ} \mathrm{C}$ at $0{ }^{\circ} \mathrm{C}$. The operating range was -40 to 70 ${ }^{\circ} \mathrm{C}$ for both the sensor and the logger. The loggers were programmed to record temperatures every six hours from September 2012 to June 2013. After which, the measurement frequency was increased to every hour so that data could be compared with 
Table 3.1 Summary of dates with at least one good time-lapse image taken at the sites from September 2012 to June 2014 and percent of good images available during each freezing season (FS).

\begin{tabular}{|c|c|c|c|c|c|}
\hline \multirow{2}{*}{ Season } & \multirow{2}{*}{ Portage } & \multicolumn{2}{|c|}{ Date } & \multirow{2}{*}{$\begin{array}{l}\text { Number } \\
\text { of days }\end{array}$} & \multirow{2}{*}{$\begin{array}{c}\text { Percent of } \\
\text { FS }(\%)\end{array}$} \\
\hline & & From & To & & \\
\hline \multirow[t]{4}{*}{$2012 / 13$} & P11 & 08-Sep & 19-Jun & 284 & 100 \\
\hline & $\mathrm{P} 16 \mathrm{~S}$ & 08-Sep & 19-Jun & 284 & 100 \\
\hline & $\mathrm{P} 16 \mathrm{~N}$ & 08-Sep & 18-Jun & 283 & 100 \\
\hline & $\mathrm{P} 23$ & 08-Sep & 19-Jun & 284 & 100 \\
\hline \multirow[t]{15}{*}{$2013 / 14$} & P11 & 11-Sep & 14-Jun & 276 & 100 \\
\hline & P16S & $\mathrm{ND}^{1}$ & ND & ND & ND \\
\hline & $\mathrm{P} 16 \mathrm{~N}$ & 11-Sep & 24-Sep & 13 & 68 \\
\hline & & 26-Sep & 08-Nov & 43 & - \\
\hline & & 13-Nov & 01-Dec & 18 & - \\
\hline & & 19-Jan & 02-Feb & 14 & - \\
\hline & & 08-Feb & 14-Jun & 126 & - \\
\hline & P23 $C 1^{2}$ & 11-Sep & 30-Oct & 49 & 99 \\
\hline & & 01-Nov & 14-Jun & 225 & - \\
\hline & P23 $C 2^{3}$ & 11-Sep & 24-Oct & 43 & 74 \\
\hline & & 26-Oct & 23-Nov & 28 & - \\
\hline & & 24-Nov & 02-Dec & 8 & - \\
\hline & & 04-Jan & 22-Jan & 18 & - \\
\hline & & 24-Jan & 30-Jan & 6 & - \\
\hline & & 09-Feb & 14-Jun & 125 & - \\
\hline
\end{tabular}

${ }^{1} \mathrm{ND}=$ no data,${ }^{2} \mathrm{C} 1=$ camera $1,{ }^{3} \mathrm{C} 2=$ camera 2. 
the time-lapse photographs taken at the same time. Air and near-surface temperatures were recorded from September 2012 to June 2016. Damage to the instruments by wildlife (P16N and P23) and wild fire (P11) resulted in missing data. During the study period, air and near-surface temperatures at P23 were only available from September 2012 to June 2013.

Additional near-surface temperature loggers were installed in September 2013 to capture greater variability in near-surface ground temperature. HOBO Water Temp Pro v2 loggers, which contain one internal sensor were placed $2-5 \mathrm{~cm}$ below the ground surface at the vertical ground temperature sensor locations. The accuracy, resolution, and operating range were the same as that of the HOBO Pro v2 logger described above.

\subsubsection{Subsurface stratigraphy}

Vertical boreholes were drilled with a hand-held peat auger to depths of $120 \mathrm{~cm}$ in September 2012 and 2013 to evaluate the subsurface conditions on and off ROW and obtain an understanding of their influence on thermal and hydrological properties of the ground. The subsurface stratigraphy was determined from the auger return (Figure 3.7). The soil type, wetness, thermal state (frozen, unfrozen), and presence of visible ice were recorded. Three to four samples were collected from 0 to $120 \mathrm{~cm}$ depth per borehole for moisture content analysis. Sample depths were based on changes in stratigraphy, wetness, and thermal state to obtain representative samples for each stratigraphic unit.

\subsubsection{Ground temperature}

Ground temperatures were measured to determine the timing and rate of active-layer freezeback, active-layer depth, permafrost temperature, the zero curtain effect at different 
(a)

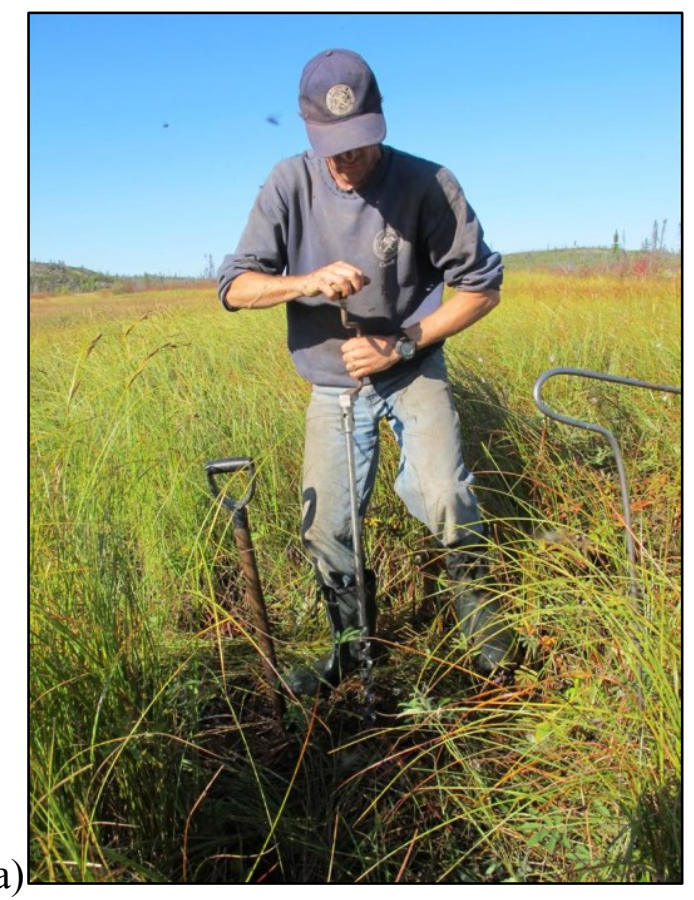

(b)

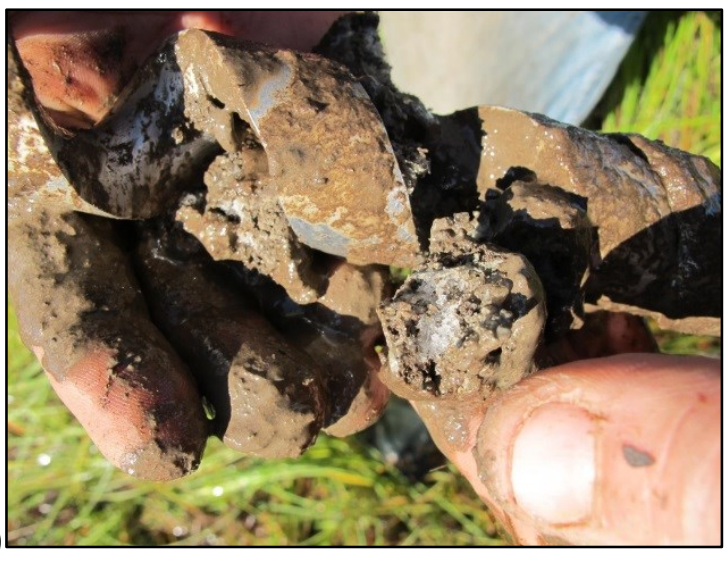

Figure 3.7 (a) Hand augering with the peat auger at portage 16 north (P16N). (b) An example of the ice-rich return on the peat auger. Photos by W. Sladen, September 2012. 
sites, and the influence of non-conductive heat flow on and off the winter road ROW, so that these factors could be correlated with overflows. Vertical arrays of ground temperature sensors were installed either by mounting on a stick or wooden dowel and placed in the augered boreholes or by placement directly in the ground of a dug out pit, which was subsequently backfilled (Figure 3.8). The sensors were placed at 15, 30, 60, and $120 \mathrm{~cm}$ depth below the ground surface, in order to compare the rate of freezeback at different locations. Depending on drilling conditions, the $120 \mathrm{~cm}$ depth was not always achieved and, instead, the deepest sensor was placed at 100 or $110 \mathrm{~cm}$ depth. The rationale for the increased thermistor spacing with depth was the decrease in the annual ground temperature variation with depth (Williams and Smith 1989). The $30 \mathrm{~cm}$ depth and the $120 \mathrm{~cm}$ depth were chosen in particular because of winter road freezeback requirements and to measure the temperature at or near the base of the active layer, respectively. In addition to the vertical array, a horizontal array at $30 \mathrm{~cm}$ depth was installed under a variety of surface conditions, usually ranging in wetness or ground disturbance (Figure 3.6). Data loggers were located off the winter road ROW and the connecting sensor cables were buried to avoid damage by wildlife and winter road operations.

Onset HOBO U12-008 4-external channel loggers were used with the TMC20HD and TMC50-HD temperature sensors, the number referring to the length of the cable in feet. The accuracy of the logger and sensor combined was $\pm 0.6^{\circ} \mathrm{C}$ at $-20{ }^{\circ} \mathrm{C}$ and \pm $0.25{ }^{\circ} \mathrm{C}$ at $0{ }^{\circ} \mathrm{C}$. The resolution was $\pm 0.03{ }^{\circ} \mathrm{C}$ at $20{ }^{\circ} \mathrm{C}$. The logger operating range was -20 to $70{ }^{\circ} \mathrm{C}$ and the sensor measurement range was -40 to $50{ }^{\circ} \mathrm{C}$ in water. The loggers were programmed to record temperatures every six hours from September 2012 to June 

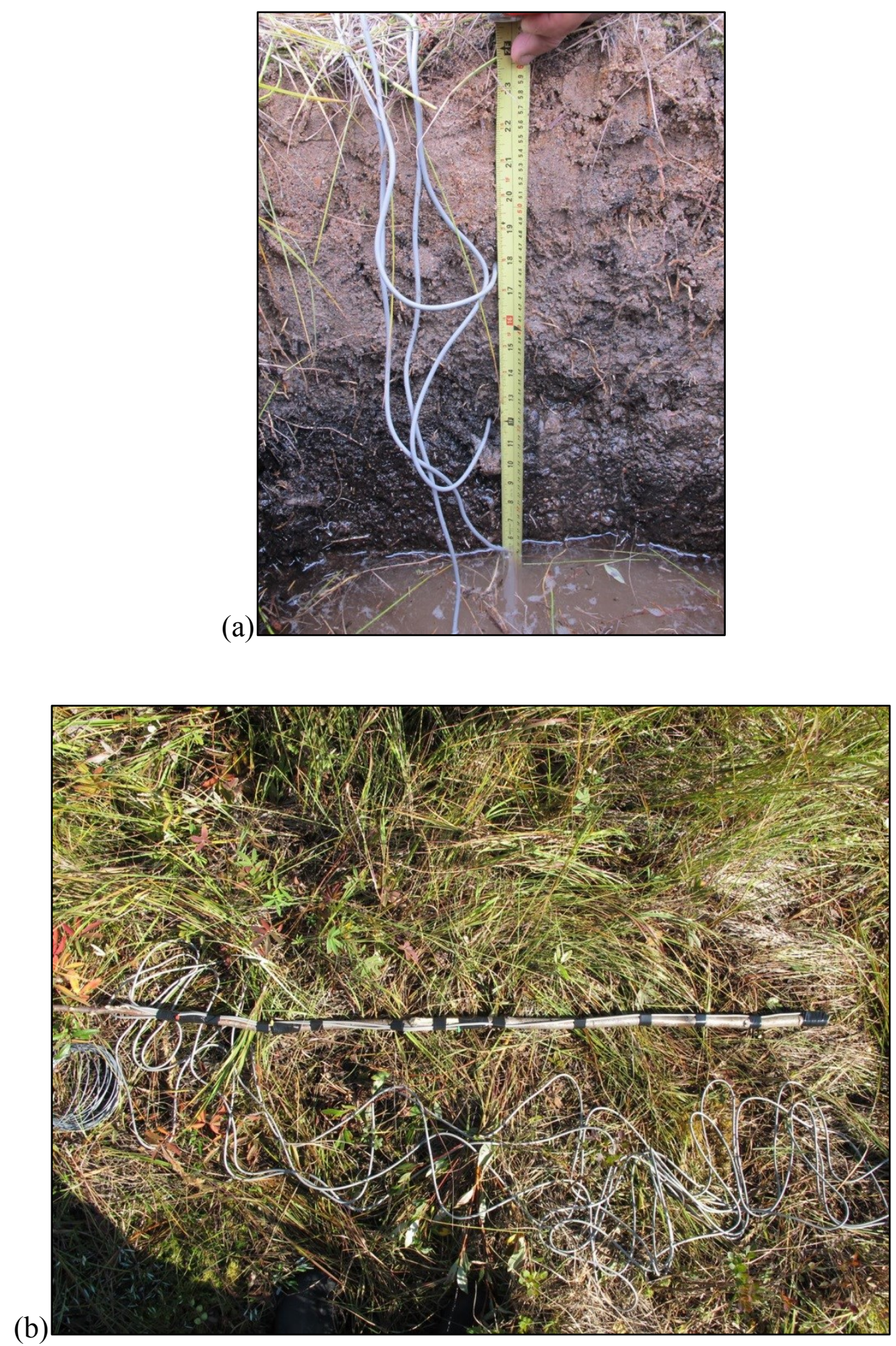

Figure 3.8 (a) Placement of sensors directly into the soil at portage 11 (P11-ROW). (b) In some cases sensors were attached to a stick (b) or a wooden dowel and then installed in a borehole. This setup is the vertical thermistor string that was installed at portage 16 north (P16N-ROW). Photos by W. Sladen, September 2012. 
2013 and every hour from June 2013 to June 2014. The more frequent interval was chosen to match the recording interval of the other instrumentation in the study.

\subsubsection{Water body temperature}

Temperatures were recorded in the water bodies near P23 to determine the timing of freezeback in relation to overflow. HOBO Water Temp Pro v2 loggers were used to record temperatures near the outlet of Lake P23 and in the watercourse between Lake P23 and the instrumentation site. Both loggers were placed at approximately $60 \mathrm{~cm}$ depth and recorded temperatures from September 2013 to June 2014.

\subsubsection{Transects}

Probing transects were surveyed at the portage sites in September 2012 and 2013 to determine the depth to the frost table or bedrock. At this time of year the frost table is commonly near its deepest position. A GPS point was taken at the end of each transect and distance along the transects was determined with a measuring tape (Figure 3.9 (a)). The depth to the frost table or bedrock was measured by probing the ground with a graduated steel rod at 2 to $5 \mathrm{~m}$ intervals, or where a noticeable change in surface conditions occurred along the transect. Probing thaw depth was effective in most areas except where bedrock was encountered and where coarse aggregate was present on the ROW. Determining the location of the frost table contributed to understanding the configuration of the zone available for suprapermafrost water flow. Surface water depth and vegetation type and height were also recorded. 

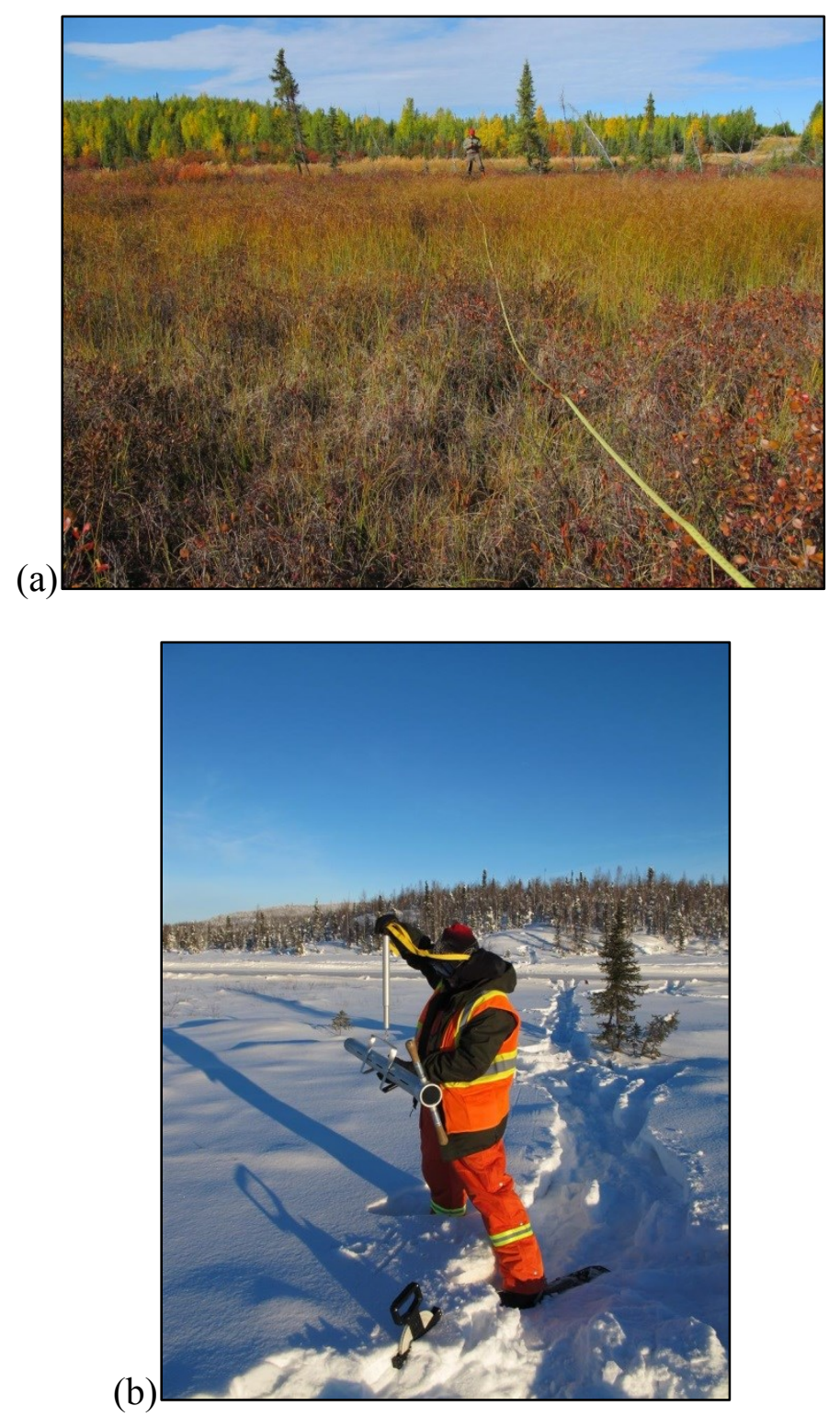

Figure 3.9 (a) View towards the northwest along the frost depth probing transect at portage P23 (September 2013). (b) Measuring snow depth and density using the Geoscientific Metric Snow Sampler at portage 23 (February 2014). Photos by W. Sladen. 


\subsubsection{Snow measurements}

Snow depth and density were measured to determine the variability in snowpack characteristics at the sites. Measurements of snow depth and density were made during the February field visits in 2013 and 2014. Snow depth was determined with a graduated wooden probe. Snow density was measured using the Geoscientific Metric Snow Sampler. The snow sampler was $1.2 \mathrm{~m}$ long with a $6 \mathrm{~cm}$ internal diameter and was based on the Environment Canada ESC 30 design (Geoscientific 2016). A spring scale and cradle were used to weigh the sampler and snow sample (Figure 3.9 (b)).

To determine the snow density, the empty sampler was weighed and then the sampler was inserted into the snowpack. The snow depth was determined using the graduations on the snow tube. The sampler and snow sample were then weighed using the spring scale. The centimetre water equivalent was determined from the calibrated scale. The snow density $\left(\rho_{\mathrm{s}}\right)$ was then calculated using:

$$
\rho_{s}=\frac{S W E}{h_{s}} \rho_{w}
$$

where SWE is the snow water equivalent, $h_{s}$ is the snow depth, and $\rho_{w}$ is the density of water. Measurements were made at each thermal installation, the snow stakes, air temperature installations, and along transects perpendicular to the road as well as across the watercourse at portage 23 . These measurements contributed to understanding the spatial variability of the snowpack at the sites.

\subsubsection{Field inspection}

The study sites were visited in February to verify the overflows observed in the photographic record. The area of overflow and the watercourse were drilled with a 
modified Cold Regions Research and Engineering Laboratory (CRREL) core barrel to determine overflow, ice, and frozen ground conditions.

\subsubsection{Water sampling}

Water samples were collected in February 2014 for isotopic and geochemical analyses to determine the potential source waters for the icings. Icing ice, watercourse ice, and groundwater samples were obtained by CRREL coring or chiseling by hand (Figure 3.10). Lake water samples were obtained by hand augering a hole through the lake ice. Snow samples were grab samples from the snowpack. The ice and snow samples were collected in plastic bags, allowed to melt, and then transferred to plastic bottles. The water samples were collected in plastic bottles.

\subsection{Laboratory testing}

\subsubsection{Moisture content and bulk density}

Soil and peat samples were collected in September 2012 and February 2014 for moisture content and bulk density determination. The samples collected during drilling of the boreholes were sealed in double plastic bags and transported to Ottawa for moisture content analysis. The wet samples were weighed and then placed in a drying oven at 84 ${ }^{\circ} \mathrm{C}$, due to the high organic content, for at least 24 hours (MacFarlane and Allen 1964). The samples were re-weighed after drying to obtain the dry weight. The soil gravimetric moisture content was determined on a wet basis (mass of water per unit mass of fieldmoist soil) (Phillips et al. 2015). The frozen core collected in February 2014 near P23OFF2 was used to determine bulk density and volumetric water content. 

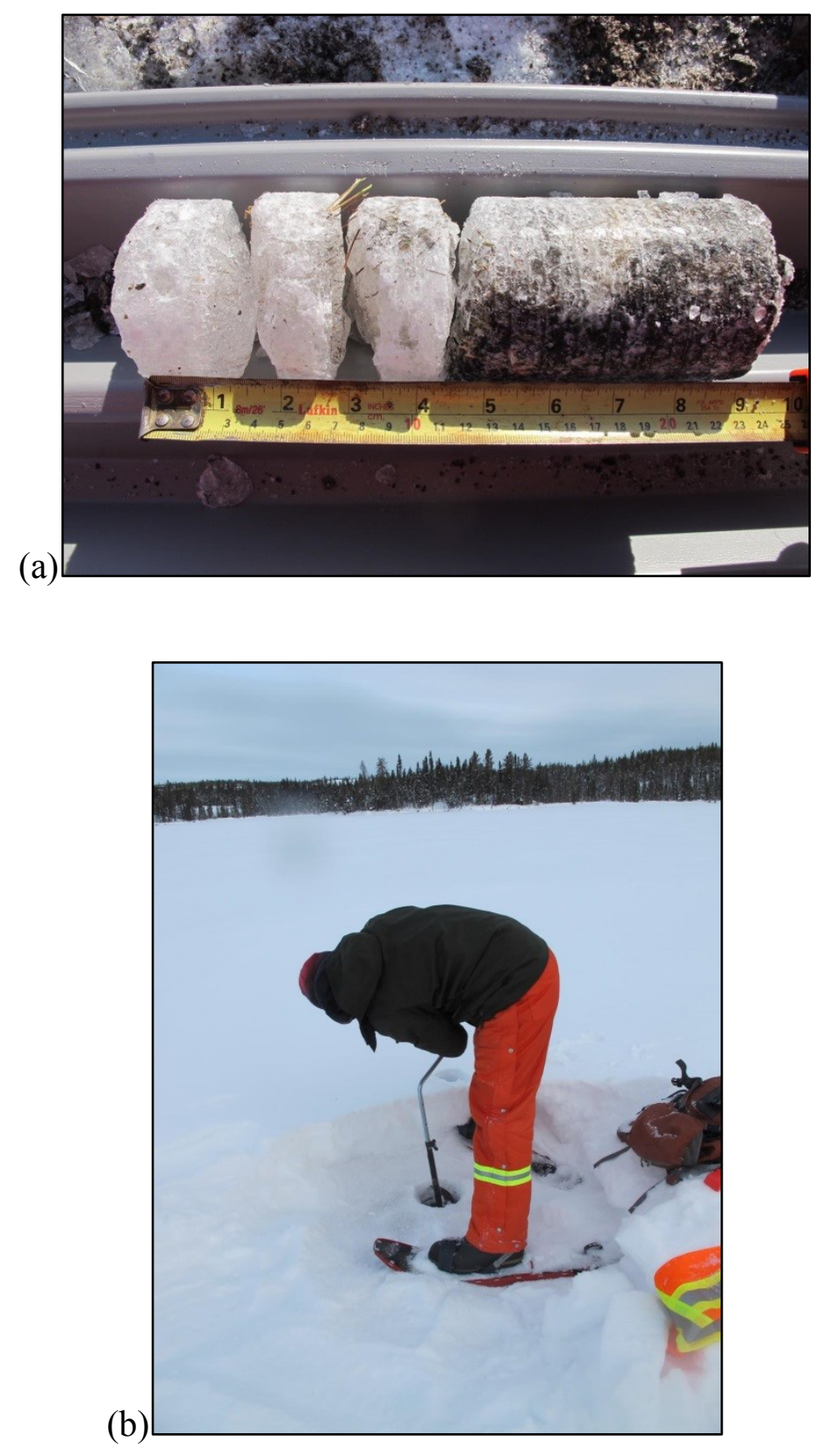

Figure 3.10 (a) CRREL core showing icing ice (left) on top of frozen peat (right) at portage P23. (b) Using an ice auger on Lake P23 to obtain a lake water sample. Photos by W. Sladen, February 2014. 


\subsubsection{Isotopic analysis}

Stable isotopes of oxygen $\left({ }^{18} \mathrm{O}\right)$ and hydrogen $\left({ }^{2} \mathrm{H}\right)$ in icing ice may provide evidence of source water (Lauriol et al. 1991, Michel 2011). This method is based on the natural variations in the heavy isotopes of water $\left({ }^{2} \mathrm{H}\right.$ and $\left.{ }^{18} \mathrm{O}\right)$ relative to the lighter ones $\left({ }^{1} \mathrm{H}\right.$ and ${ }^{16} \mathrm{O}$ ) that occur during phase changes and mixing of water throughout the hydrological cycle (Gibson et al. 1993). Globally, the isotopic composition of precipitation forms a strong linear relation between the oxygen and hydrogen ratios, known as the global meteoric water line (GMWL): $\delta^{2} \mathrm{H}=8 \delta^{18} \mathrm{O}+10$ (Craig 1961). Local meteorological effects, such as temperature, humidity, latitude, altitude, and distance from a moisture source, cause the isotopic composition of the precipitation to vary slightly from the GMWL, thereby forming a local meteoric water line (LMWL) (Dansgaard 1964, Fritz et al. 1987, Moorman et al. 1996, Michel 2011) Seasonal variations in isotopic composition, mainly due to temperature-dependent effects on condensation, result in systematic shifts along the LMWL (Gibson et al. 1993). Precipitation formed under colder temperatures, such as snow, is depleted in the heavy isotopes resulting in more negative ratios, while the opposite occurs under warmer conditions. The isotopic composition of groundwater tends to be similar to the average annual precipitation, as a result of integration at depth of snow and rainfall without effects of evaporation (Michel 1986, Gibson et al. 1993, 1998). In contrast, surface water that has been exposed to different rates of evaporation throughout the ice-free season experiences a systematic enrichment of ${ }^{18} \mathrm{O}$ and ${ }^{2} \mathrm{H}$ in the residual water (Gibson et al. 1993, Gibson et al. 1998). Surface waters from the same catchment commonly plot along a well-defined local evaporation line, whose slope is less than the LMWL. 
Water for isotopic analysis was transferred from the water samples using a syringe to $1.5 \mathrm{~mL}$ glass vials. The samples were sent to the University of Ottawa G.G. Hatch Stable Isotope Laboratory for oxygen and hydrogen isotope analysis.

\subsubsection{Geochemical analysis}

Water from the samples described in section 3.5.9 was also submitted to the Taiga Environmental Laboratory in Yellowknife for geochemical analysis. The icing ice, watercourse ice, groundwater, and lake water samples were tested for dissolved organic carbon, apparent colour, specific conductivity, $\mathrm{pH}$, and major ions including calcium, chloride, fluoride, magnesium, nitrate, nitrite, potassium, sodium, and sulphate. The purpose of determining the geochemistry of the water and ice was to evaluate the source of the overflows in the study region.

\subsection{Maintenance logs}

The TCWR maintenance logs at Dome Lake maintenance camp, located at km 30, were reviewed in February 2014 to determine the history of overflow-related maintenance issues encountered during construction and operation of the winter road. Logs were available for the operating seasons 2005/06 to 2012/13, inclusive, and represented the maintenance notes for the southernmost $120 \mathrm{~km}$ of the TCWR. The logs covered the period from camp opening, which ranged from December $12^{\text {th }}$ to $29^{\text {th }}$, to camp shut down, which ranged from March $22^{\text {nd }}$ to April $8^{\text {th }}$. Construction of the road proceeded north from Dome Lake with work at portages 11, 16, and 23 done in sequence. Therefore, the logs did not cover the beginning of the freezeback period. Days with log entries clearly related to water issues from overflow were used to determine the level of overflow activity in mid and late winter. 


\subsection{Analytical methods}

\subsubsection{Air temperature}

Air temperature relations among the study sites, as well as Yellowknife, were characterized by determining the principal axes rather than with least-squares linear regression lines, to account for error in both variables (Mark and Church 1977).

\subsubsection{Freezing season}

Icings occur when air temperatures are below $0{ }^{\circ} \mathrm{C}$. Daily mean air temperatures $\left(\mathrm{T}_{\mathrm{a}}\right)$ from the study sites and Yellowknife were used to determine the start and end of the freezing season. The beginning of the freezing season $\left(\mathrm{FS}_{\mathrm{A}}\right)$ was defined by the first day in autumn when $\mathrm{T}_{\mathrm{a}}$ fell below $0{ }^{\circ} \mathrm{C}$ and remained so for at least three consecutive days. The end of the freezing season was defined as the last day in spring before three or more consecutive days with $\mathrm{T}_{\mathrm{a}}$ above $0{ }^{\circ} \mathrm{C}$. The start of the freezing season based on ground surface temperatures $\left(\mathrm{FS}_{\mathrm{G}}\right)$ occurred when the hourly ground surface temperature stayed near $0{ }^{\circ} \mathrm{C}$ for at least 24 hours.

\subsubsection{Air temperature fluctuations}

Warming and cooling air temperature fluctuations were determined in relation to overflows. Temperature fluctuations were determined using $\mathrm{T}_{\mathrm{a}}$. A warming or cooling period was determined as a monotonic sequence of days during the freezing season with increasing or decreasing $T_{a}$, respectively. The duration of a warming or cooling period was its number of days. The magnitude of warming or cooling was the total temperature change over the period. 


\subsubsection{Snowpack}

Similar to air temperature, snowpack relations among the study sites and Yellowknife Airport were characterized by determining the principal axes, rather than the leastsquares linear regression lines, to account for error in both variables (Mark and Church 1977).

\subsubsection{Non-conductive heat flow}

To assess the possibility of non-conductive heat flow, the temperature difference (dT) between readings taken at 6 -hr intervals was calculated for the freezing season (Kane et al. 2001). A positive dT represented an increase in temperature which is often associated with diurnal warming, whereas a negative dT was associated with diurnal cooling. The precision of the sensors was $\pm 0.03{ }^{\circ} \mathrm{C}$. Temperature differences greater than $0.5^{\circ} \mathrm{C}$ over 6 hours were highlighted as episodes where non-conductive heat flow may have occurred.

\subsubsection{Freezeback}

The start of freezeback was defined as when the daily mean ground surface temperature $\left(\mathrm{T}_{\mathrm{s}}\right)$ dropped and remained below $0{ }^{\circ} \mathrm{C}$. The freezing front was considered to have passed a particular depth when daily mean ground temperature $\left(\mathrm{T}_{\mathrm{g}}\right)$ fell below $-0.5^{\circ} \mathrm{C}$ and continued to decrease steadily. The end of the freezeback period was defined when the temperature at the top of permafrost $\left(\mathrm{T}_{\mathrm{TOP}}\right)$ dropped below $-0.5^{\circ} \mathrm{C}$. The zero curtain referred to the period during the freezing season when $\mathrm{T}_{\mathrm{g}}$ at depth remained near $0{ }^{\circ} \mathrm{C}$ before dropping below $-0.5^{\circ} \mathrm{C}$. 


\subsubsection{Overflows}

The date and duration of overflows were determined from the photographic record at the sites. The timing of flooding was determined by the first image in which wetness was observed on the ground or snow surface. Subsequent images showing the wet area increasing in size, or where the surface still appeared wet as opposed to freezing, were considered part of the same event and were used to determine the duration of overflow. The range in timing of first and last decipherable daily images fluctuated with daylight through the winter. Therefore overflows observed in the first photo of the day, may have been initiated at any time between the last visible image of the night before, typically between 17:00 and 19:00, and the morning image, commonly 9:00, 10:00 or 11:00.

\subsection{Modelling frost penetration}

The rate of frost penetration was modelled using a modified form of the Stefan equation that accounts for sensible heat storage, equation [2-1] (section 2.3) (Kurylyk and Hayashi 2016). The variable $T_{s}$ was accounted for by using a cumulative average $T_{s}$ between time 0 and time $t$ in determining daily frost penetration. Homogeneous soil conditions and an initial $\mathrm{T}_{\mathrm{s}}$ of $0{ }^{\circ} \mathrm{C}$ were assumed.

\subsection{Limitations}

Field visits were limited in number and duration. Fall and winter field visits comprised a maximum of one day per site. As a result, this study relied heavily on automated recording equipment rather than in situ field observations. Cameras were set in view of anticipated overflows and therefore may have missed some overflow events. Any damage to instrumentation or malfunctioning sensors resulted in no data recovery for periods between field visits. 


\section{Chapter: RESULTS}

\subsection{Introduction}

The occurrence of icings has been linked to meteorological variables that drive water availability and the rate of freezeback, and to anthropogenic causes which alter the hydraulic transmissivity of the ground (e.g., van Everdingen 1978, Morse and Wolfe 2015). The first section of this chapter examines air temperature and snow accumulation during the study period because these factors drive freezeback. The ground thermal regime and variability in active-layer freezeback at the study sites are then presented along with field observations of water flow and moisture conditions in the ground. Stable isotope and geochemical results are evaluated for indicators of the source water for the overflows. Following this, the overflows are outlined and related to air and ground temperature, snowfall, freezeback, water source, rainfall, and winter road operations. Finally, the Tibbitt to Contwoyto Winter Road (TCWR) historical icing record is examined.

\subsection{Air temperature}

The daily mean air temperature recorded during the study period is shown for P16S in Figure 4.1. Table 4.1 summarizes the correlations between the study site air temperatures as well as for Yellowknife Airport (YZF), the closest Environment Canada weather station to the study area. The air temperatures at the sites and YZF were highly correlated, with coefficients of determination $\left(\mathrm{r}^{2}\right)$ greater than 0.98 and slopes of 1.0, indicating that the sites and YZF were situated within the same climatic system. The intercepts ranged from -2.4 to $-0.1{ }^{\circ} \mathrm{C}$ and indicated slight cooling with latitude. 


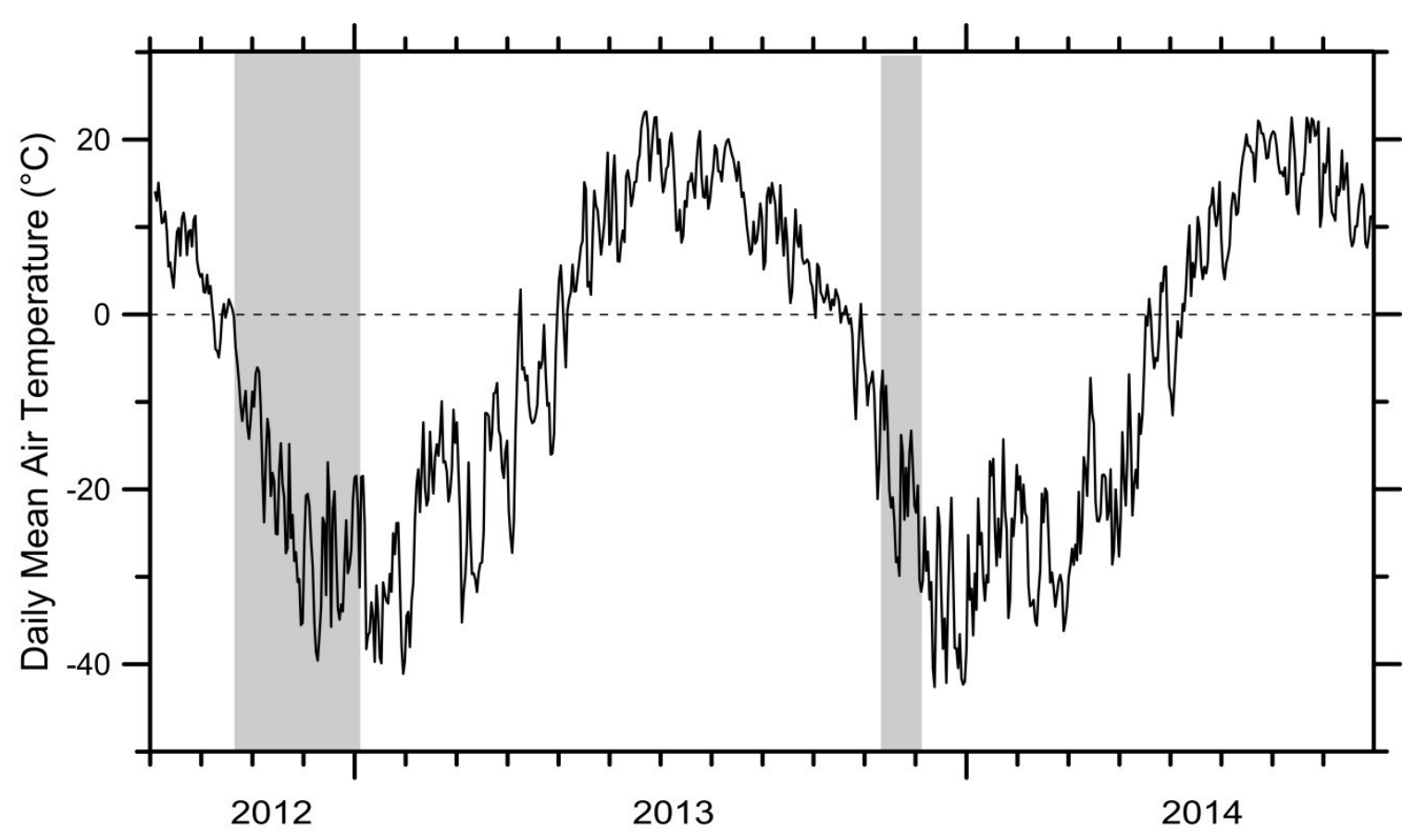

Figure 4.1 Daily mean air temperatures at P16S from September 2012 to September 2014. The periods of observed overflows are shaded in grey. 
Table 4.1 Correlation analyses for daily mean air temperatures at the study sites and the Yellowknife Airport (YZF) for September 2012 to June 2016 and fitted principal axes: (a) coefficient of determination, $\mathrm{r}^{2}$; (b) slope of the principal axis; (c) intercept of the principal axis; and (d) number of observations.

(a) Coefficient of Determination, $\mathrm{r}^{2}$

\begin{tabular}{|c|c|c|c|c|c|}
\hline \multirow{6}{*}{ 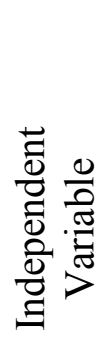 } & & \multicolumn{4}{|c|}{ Dependent Variable } \\
\hline & & P11 & P16S & $\mathrm{P} 16 \mathrm{~N}$ & P23 \\
\hline & YZF & 0.989 & 0.990 & 0.989 & 0.980 \\
\hline & P11 & - & 0.997 & 0.997 & 0.991 \\
\hline & P16S & - & - & 0.999 & 0.995 \\
\hline & $\mathrm{P} 16 \mathrm{~N}$ & - & - & - & 0.993 \\
\hline
\end{tabular}

(b) Slope of Principal Axis

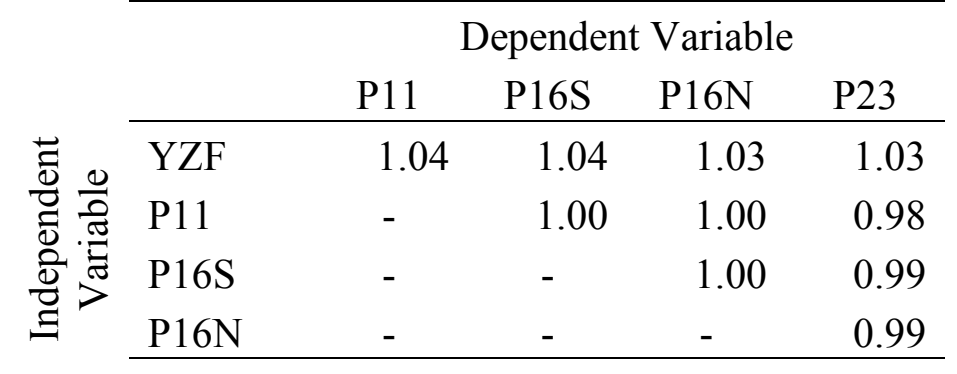

(c) Intercept of Principal Axis

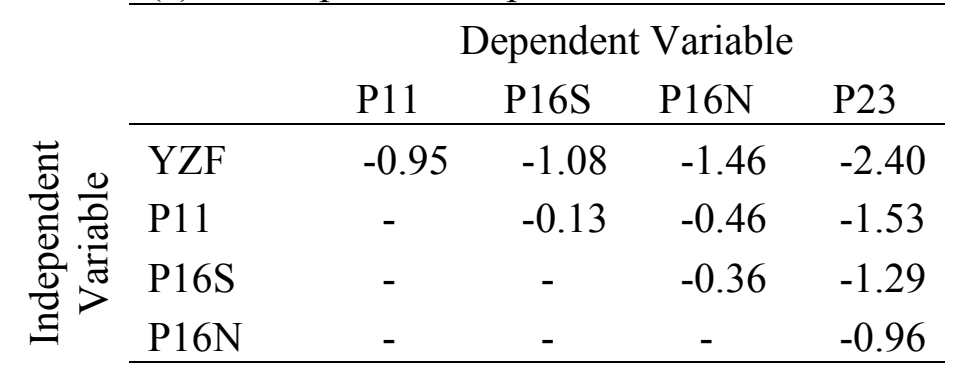

(d) Number of Observations

\begin{tabular}{|c|c|c|c|c|c|}
\hline \multirow{6}{*}{ 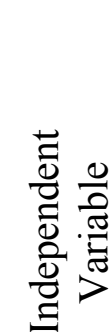 } & & \multicolumn{4}{|c|}{ Dependent Variable } \\
\hline & & P11 & P16S & $\mathrm{P} 16 \mathrm{~N}$ & P23 \\
\hline & YZF & 1282 & 1327 & 1172 & 893 \\
\hline & P11 & - & 1331 & 1177 & 929 \\
\hline & $\mathrm{P} 16 \mathrm{~S}$ & - & - & 1222 & 930 \\
\hline & $\mathrm{P} 16 \mathrm{~N}$ & - & - & - & 777 \\
\hline
\end{tabular}




\subsubsection{Freezing season}

Table 4.2 summarizes the start and end of the freezing seasons and the monthly and seasonal mean air temperatures. The freezing seasons $\left(\mathrm{FS}_{\mathrm{A}}\right)$ started in mid-October and ended in late-April or early May in both years. The $\mathrm{FS}_{\mathrm{A}}$ mean air temperatures (October to April) were similar for the two years at all the sites, differing by 0 to $0.4^{\circ} \mathrm{C}$, as were the freezing degree days (Table 4.2). However, monthly mean air temperatures (MMAT) varied interannually by 0.7 to $7.6^{\circ} \mathrm{C}$. October and November MMATs were 2.8 to $3.8^{\circ} \mathrm{C}$ lower in 2012/13, whereas December was 3.4 to $4.0{ }^{\circ} \mathrm{C}$ lower in 2013/14. These results showed that the timing and mean temperature of the freezing seasons were similar but the first portion of the freezing season was colder in 2012/13 than in 2013/14. According to the YZF meteorological record, the study period freezing season mean air temperatures were about $2.3{ }^{\circ} \mathrm{C}$ lower than the 1981-2010 average (Table 4.2).

\subsubsection{Warming periods}

Table 4.3 summarizes the subfreezing warming periods $\geq 5^{\circ} \mathrm{C}$ for the study period. The frequency of warming periods was similar among the sites and between the years, ranging from $28(2012 / 13)$ to $29(2013 / 14)$. Warming periods occurred in every month (Table 4.3). The duration of the warming periods ranged from 1 to 7 days, and averaged 2 to 3 days. Cumulative warming $\geq 5{ }^{\circ} \mathrm{C}$ ranged from 7.2 to $29.9^{\circ} \mathrm{C}$. Maximum 1-day warming in $2012 / 13$ was about $15^{\circ} \mathrm{C}$ in December, while in $2013 / 14$ it was about $17^{\circ} \mathrm{C}$ in November. Therefore, subfreezing warming periods on the scale observed to be associated with icings occurred frequently during the study period. 
Table 4.2 Freezing season $\left(\mathrm{FS}_{\mathrm{A}}\right)$, mean temperature, and freezing degree days $\left(\mathrm{FDD}_{\mathrm{A}}\right)$ based on air temperatures for Yellowknife Airport (YZF) and the study sites for 2012/13, 2013/14, and the 1989-2010 average (Environment Canada 2016).

\begin{tabular}{|c|c|c|c|c|c|c|c|c|c|c|c|c|c|}
\hline & & \multicolumn{2}{|c|}{ Freezing Season } & \multicolumn{8}{|c|}{ Mean Air Temperature $\left({ }^{\circ} \mathrm{C}\right)$} & \multirow[b]{2}{*}{$\mathrm{FS}_{\mathrm{A}}$} & \multirow[b]{2}{*}{$\mathrm{FDD}_{\mathrm{A}}$} \\
\hline & & Start & End & Oct & Nov & Dec & Jan & Feb & Mar & Apr & Year & & \\
\hline \multirow{5}{*}{$2012 / 13$} & $\mathrm{YZF}^{1}$ & $10-$ Oct & 02-May & -1.4 & -17.5 & -27.2 & -28.9 & -20.1 & -17.6 & -9.4 & -4.8 & -17.4 & 3732 \\
\hline & P11 & 09-Oct & 01-May & -2.7 & -19.3 & -28.1 & -30.4 & -20.5 & -19.8 & -10.3 & -6.0 & -18.7 & 4010 \\
\hline & $\mathrm{P} 16 \mathrm{~S}$ & 09-Oct & 01-May & -2.7 & -19.5 & -28.4 & -30.8 & -20.7 & -20.3 & -11.1 & -6.2 & -19.1 & 4083 \\
\hline & $\mathrm{P} 16 \mathrm{~N}$ & 09-Oct & 01-May & -2.9 & -19.6 & -29.0 & -31.0 & -21.0 & -20.7 & -11.5 & -6.6 & -19.4 & 4145 \\
\hline & $\mathrm{P} 23$ & 09-Oct & 01-May & -3.8 & -20.5 & -28.5 & -31.7 & -21.9 & -21.1 & -12.4 & - & -20.0 & 4266 \\
\hline \multirow{5}{*}{$2013 / 14$} & $\mathrm{YZF}^{1}$ & 24-Oct & 19-Apr & 1.3 & -14.1 & -30.7 & -25.3 & -26.1 & -20.4 & -7.4 & -5.0 & -17.5 & 3786 \\
\hline & P11 & 22-Oct & 26-Apr & 0.1 & -15.5 & -32.1 & -26.3 & -28.0 & -22.5 & -9.5 & - & -19.1 & 4100 \\
\hline & $\mathrm{P} 16 \mathrm{~S}$ & $22-$ Oct & 26-Apr & 0.1 & -15.7 & -32.1 & -26.4 & -28.0 & -22.4 & -9.8 & -6.2 & -19.1 & 4112 \\
\hline & $\mathrm{P} 16 \mathrm{~N}$ & $22-$ Oct & 26-Apr & -0.1 & -15.8 & -32.4 & -26.8 & -28.4 & -22.8 & -10.1 & -6.6 & -19.4 & 4171 \\
\hline & $\mathrm{P} 23$ & - & - & - & - & - & - & - & - & _ & - & - & - \\
\hline 1989-2010 & YZF & 09-Oct & 24-Apr & -1.7 & -13.7 & -21.8 & -25.6 & -22.9 & -16.8 & -5.3 & -4.3 & -15.1 & 3343 \\
\hline
\end{tabular}

${ }^{1}$ Environment Canada Yellowknife Henderson Station data were used where YZF data were missing. 
Table 4.3 Summary of subfreezing warming periods $\geq 5^{\circ} \mathrm{C}$ at P11 for the $2012 / 13$ and 2013/14 freezing seasons.

\begin{tabular}{|c|c|c|c|c|c|c|c|c|}
\hline & \multicolumn{8}{|c|}{$2012 / 13$} \\
\hline & Oct & Nov & Dec & Jan & Feb & Mar & Apr & Season \\
\hline $\begin{array}{l}\text { Number of warming } \\
\text { periods } \geq 5^{\circ} \mathrm{C}\end{array}$ & 1 & 4 & 6 & 5 & 6 & 4 & 2 & 28 \\
\hline Average duration (d) & 3 & 2.3 & 2.5 & 1.2 & 2.5 & 4 & 4.5 & 2.6 \\
\hline Minimum duration (d) & - & 2 & 1 & 1 & 2 & 2 & 4 & 1 \\
\hline Maximum duration (d) & - & 3 & 4 & 2 & 5 & 7 & 5 & 7 \\
\hline $\begin{array}{l}\text { Maximum 1-day } \\
\text { warming }\left({ }^{\circ} \mathrm{C}\right)\end{array}$ & 4.0 & 12.3 & 15.5 & 11.9 & 7.9 & 13.5 & 9.4 & 15.5 \\
\hline \multirow[t]{3}{*}{$\begin{array}{l}\text { Maximum period } \\
\text { warming }\left({ }^{\circ} \mathrm{C}\right)\end{array}$} & 7.2 & 13.5 & 17.5 & 13.0 & 20.0 & 21.2 & 29.9 & 29.9 \\
\hline & \multicolumn{8}{|c|}{$2013 / 14$} \\
\hline & Oct & Nov & Dec & Jan & $\mathrm{Feb}$ & Mar & Apr & Season \\
\hline $\begin{array}{l}\text { Number of warming } \\
\text { periods } \geq 5^{\circ} \mathrm{C}\end{array}$ & 1 & 5 & 3 & 8 & 1 & 7 & 4 & 29 \\
\hline Average duration (d) & 3 & 1.6 & 2.3 & 1.5 & 4 & 2.1 & 2.3 & 2 \\
\hline Minimum duration (d) & - & 1 & 2 & 1 & 4 & 1 & 1 & 1 \\
\hline Maximum duration (d) & - & 3 & 3 & 2 & 4 & 5 & 4 & 5 \\
\hline $\begin{array}{l}\text { Maximum 1-day } \\
\text { warming }\left({ }^{\circ} \mathrm{C}\right)\end{array}$ & 7.9 & 17.2 & 11.6 & 14.6 & 8.5 & 9.3 & 10.1 & 17.2 \\
\hline $\begin{array}{l}\text { Maximum period } \\
\text { warming }\left({ }^{\circ} \mathrm{C}\right)\end{array}$ & 15.0 & 17.2 & 21.4 & 17.3 & 16.1 & 13.9 & 15.5 & 21.4 \\
\hline
\end{tabular}




\subsection{Snow accumulation}

Figure 4.2 shows the snowpack development at P11, P16N, P23, and YZF for the study period. Table 4.4 summarizes the correlations between P11, P23, and YZF snow accumulation. Snow accumulation was highly correlated between all three sites for the overflow period, suggesting that accumulation events were coincident throughout the region. The rates of accumulation were site specific, though similar, as shown by the slopes and intercepts of the fitted principal axes for these data sets.

Snow accumulation started around October $21^{\text {st }}$, which was within 12 days of the start of the freezing season in both years. In 2012/13, the snowpack built up continuously until late February at P11 and YZF, whereas at P23 there was limited accumulation in January. In 2013/14 the YZF record indicated more of a step-wise development of the snowpack, levelling out after mid-January, and the available data showed a similar pattern at the portages. The largest one-day snowfall observed at the sites was about 8 $\mathrm{cm}$, otherwise, daily snowfall generally ranged from $0-4 \mathrm{~cm}$.

The field snow depth and density measurements are summarized in Figure 4.3. The variability in average snow depth among the sites was consistent in both years. The average snow depth at $\mathrm{P} 23$ was $8-18 \mathrm{~cm}$ less than at the three southern sites. Average snow depths ranged from 36 to $54 \mathrm{~cm}$ in February 2013 and were consistently greater by $2-5 \mathrm{~cm}$ in February 2014. The average snow density at the three southern sites was slightly higher in 2013/14 than in 2012/13, while at P23, the average snow density was similar in both years $\left(0.13 \mathrm{~g} \mathrm{~cm}^{-3}\right)$. Overall snow densities were low when compared to other measurements in the region (e.g., Karunaratne 2011, Wolfe et al. 2011). This may be due to the timing of the snow density measurements being one to two months earlier in 


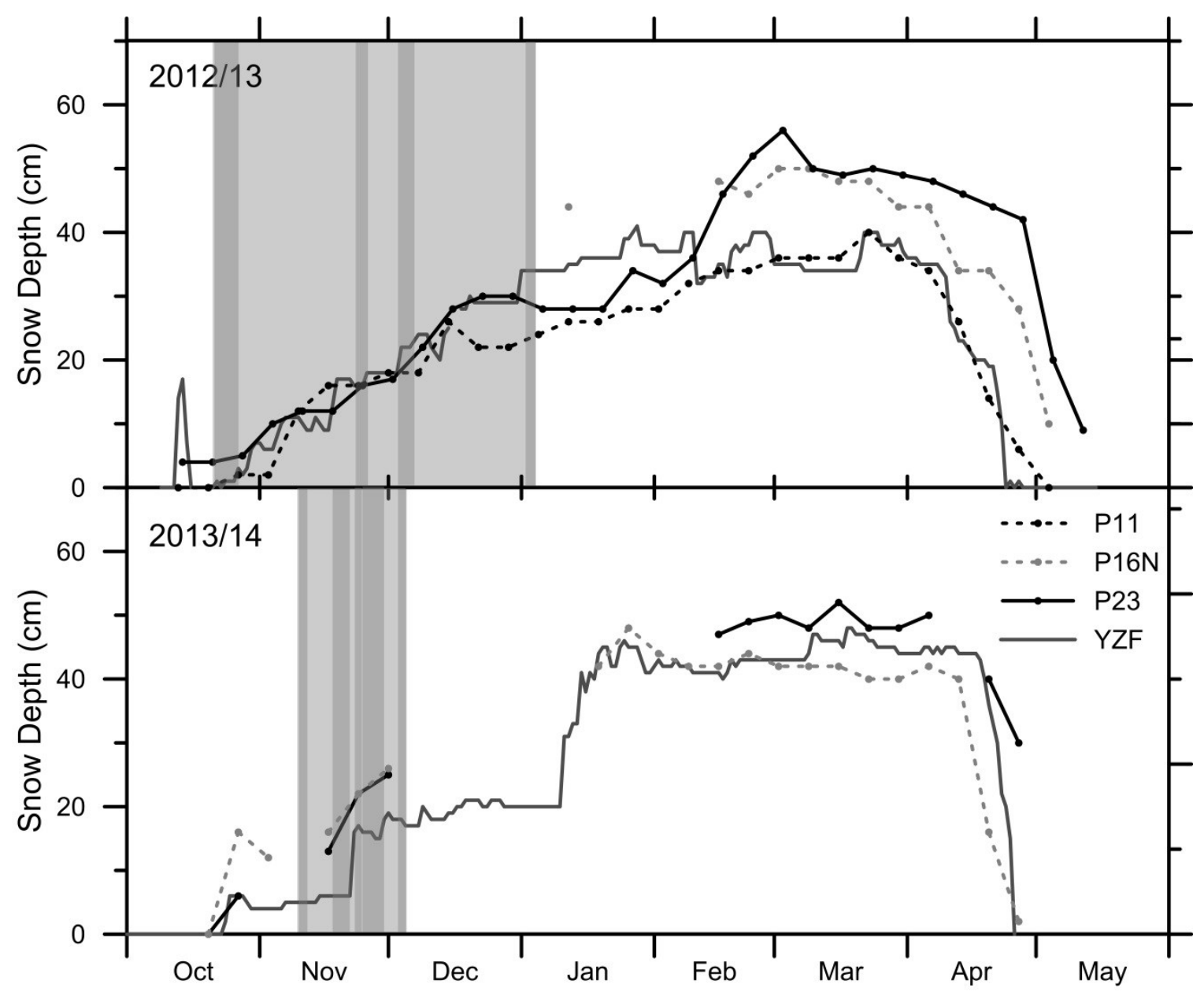

Figure 4.2 Snowpack development at P11, P16N, and P23 for 2012/13 (above) and at P16N and P23 for 2013/14 (below) as observed from the time-lapse photography. The snow depth reported at Yellowknife Airport (YZF) is also included (Environment Canada 2016). The light grey shaded areas represent the period of observed overflows at P23; the dark grey shaded areas represent observed overflow events. 
Table 4.4 Correlation analyses for snow accumulation at P11, P23, and Yellowknife Airport (YZF) for 2012/13 and fitted principal axes: (a) coefficient of determination, $\mathrm{r}^{2}$; (b) slope of the principal axis; (c) intercept of the principal axis; and (d) number of observations for the freezing season (Oct-Apr) and the period of observed overflows (Oct-Jan).

(a) Coefficient of Determination, $\mathrm{r}^{2}$

\begin{tabular}{cccccccc}
\hline \multicolumn{3}{c}{ Freezing Season } & & \multicolumn{3}{c}{ Overflow Period } \\
\cline { 1 - 3 } \cline { 6 - 7 } \cline { 5 - 7 } YZF & P11 & P23 & & \multicolumn{3}{c}{ P11 } & P23 \\
P11 & 0.867 & 0.452 & & YZF & 0.810 & 0.904 \\
& - & 0.614 & & P11 & - & 0.865 \\
\hline
\end{tabular}

(b) Slope of Principal Axis

\begin{tabular}{|c|c|c|c|c|c|}
\hline \multicolumn{3}{|c|}{ Freezing Season } & \multicolumn{3}{|c|}{ Overflow Period } \\
\hline & P11 & $\mathrm{P} 23$ & & P11 & $\mathrm{P} 23$ \\
\hline YZF & 0.87 & 1.21 & YZF & 0.79 & 0.90 \\
\hline P11 & - & 1.46 & P11 & - & 1.15 \\
\hline
\end{tabular}

(c) Intercept of Principal Axis

\begin{tabular}{|c|c|c|c|c|c|}
\hline \multicolumn{3}{|c|}{ Freezing Season } & \multicolumn{3}{|c|}{ Overflow Period } \\
\hline & P11 & $\mathrm{P} 23$ & & P11 & $\mathrm{P} 23$ \\
\hline YZF & 0.58 & 2.21 & YZF & 1.01 & 1.89 \\
\hline P11 & - & -0.93 & P11 & - & 0.57 \\
\hline
\end{tabular}

(d) Number of Observations

\begin{tabular}{|c|c|c|c|c|c|}
\hline \multicolumn{3}{|c|}{ Freezing Season } & \multicolumn{3}{|c|}{ Overflow Period } \\
\hline & P11 & $\mathrm{P} 23$ & & $\mathrm{P} 11$ & $\mathrm{P} 23$ \\
\hline YZF & 200 & 214 & YZF & 80 & 84 \\
\hline P11 & - & 205 & P11 & - & 85 \\
\hline
\end{tabular}



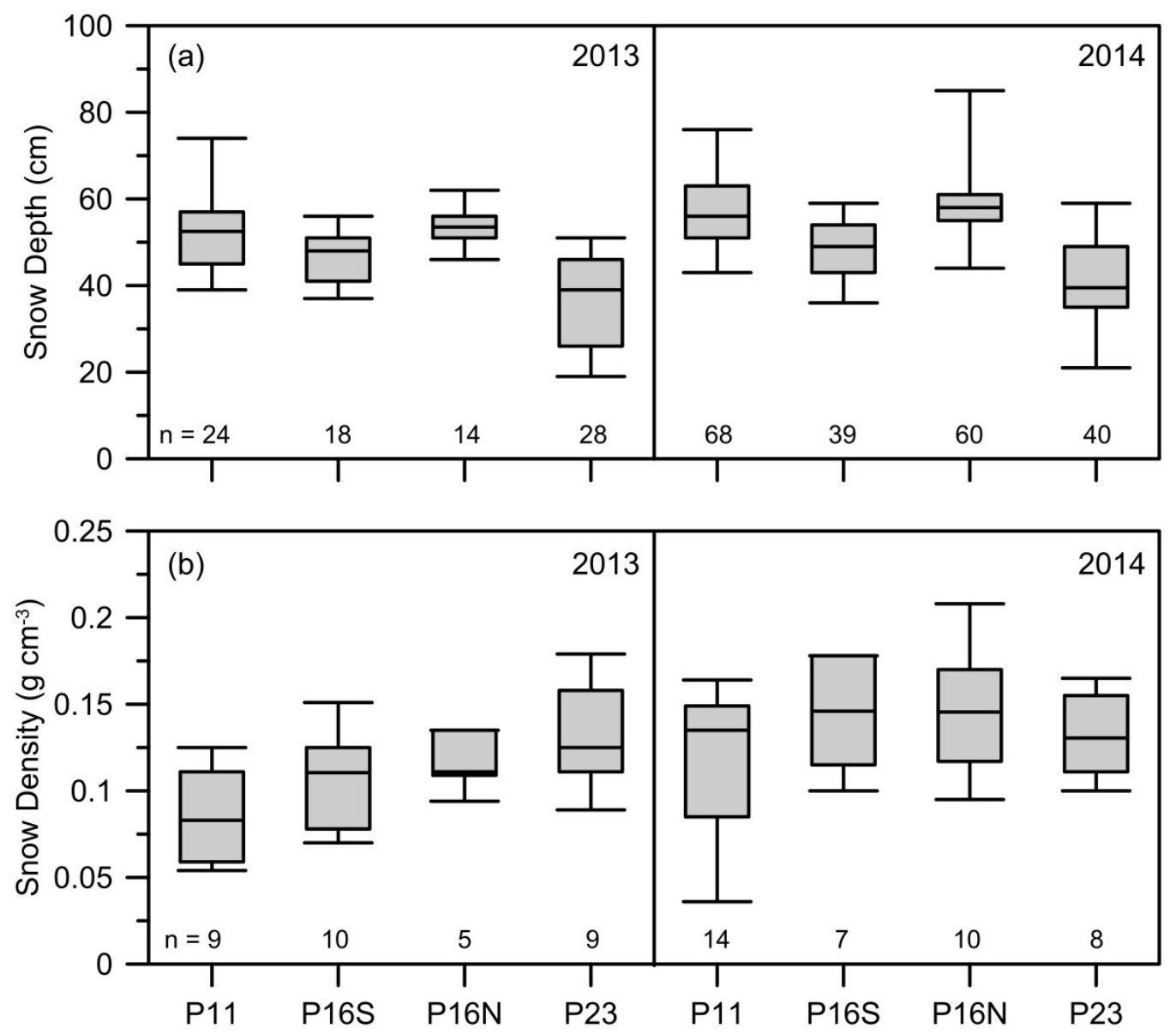

Figure 4.3 Snow depth (a) and density (b) measured at the study sites in February 2013 and 2014. Box and whisker plots present median, minimum, maximum, lower quartile, and upper quartile values of $\mathrm{n}$ measurements. 
this study than in the cited works (Karunaratne 2011, Wolfe et al. 2011), as increased snow densification would be expected with time. The average snowpack adjacent to the winter road was considerably denser $\left(0.23 \mathrm{~g} \mathrm{~cm}^{-3}\right)$ than off ROW $\left(0.12 \mathrm{~g} \mathrm{~cm}^{-3}\right)$. This was expected, as winter road snow clearing creates a denser snowbank parallel to the ROW.

\subsection{Ground thermal regime}

The daily mean ground temperatures at $15,30,60$, and $120 \mathrm{~cm}$ depth at P16S and P23 for the study period are shown in Figure 4.4. These sites capture the range in ground temperatures for drier and wetter environments, respectively. Greater annual amplitude in ground temperature was observed beneath the ROW than off ROW due to snow clearing in winter and less vegetation cover in summer. Permafrost was encountered at all drill sites except off ROW at P11, where water was up to $95 \mathrm{~cm}$ deep. The top of permafrost was at approximately $120 \mathrm{~cm}$ depth for most sites, except off ROW in the raised bog environment at $\mathrm{P} 16 \mathrm{~S}$ and $\mathrm{P} 23$, where it was closer to $60 \mathrm{~cm}$. The shallower depth at the drier sites is likely due to the thermal properties of the peat (Nelson et al. 1985).

The annual mean temperatures near the top of permafrost $\left(\mathrm{T}_{\mathrm{TOP}}\right)$ are summarized in Table 4.5. $\mathrm{T}_{\text {TOP }}$ was lower on $\operatorname{ROW}\left(-1.4\right.$ to $\left.-3.5^{\circ} \mathrm{C}\right)$ than off $\operatorname{ROW}\left(0\right.$ to $\left.-2.1^{\circ} \mathrm{C}\right)$ as a result of greater cooling due to snow removal (Figure 4.4). The ranges in $\mathrm{T}_{\mathrm{TOP}}$ were consistent with $\mathrm{T}_{\mathrm{TOP}}$ reported from elsewhere in the region (e.g., Karunaratne 2011).

\subsubsection{Active-layer freezeback}

Table 4.6 summarizes the active-layer freezeback at the sites. The start of freezeback was similar among the sites and began within days of the start of the $\mathrm{FS}_{\mathrm{A}}$. Ground 

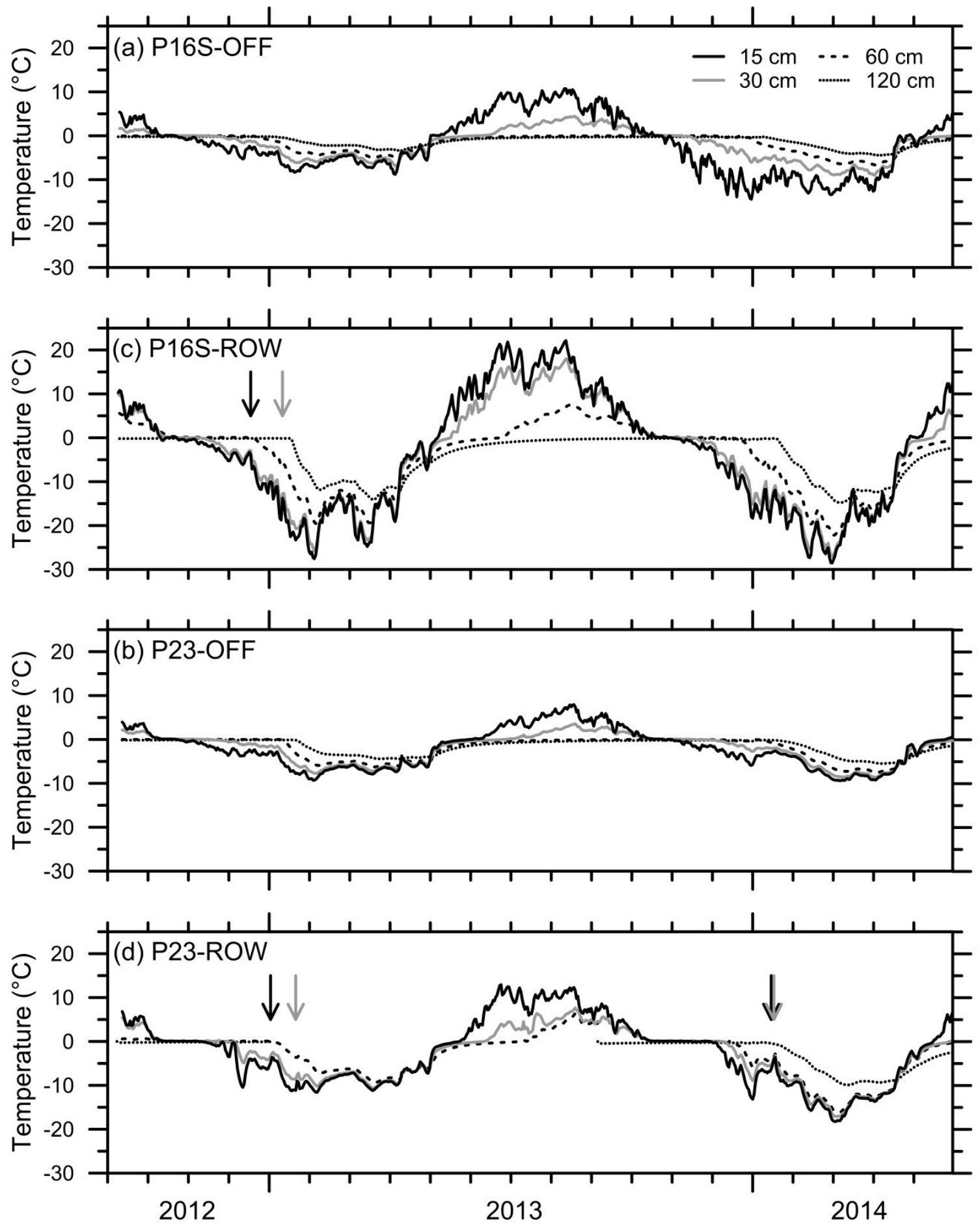

Figure 4.4 Daily mean temperatures at 15, 30, 60, and $120 \mathrm{~cm}$ depth off and on ROW at sites (a, b) P16S and (c, d) P23 from September 2012 to June 2014. The black arrows mark the first snow clearing and the grey arrows mark the first flooding of the ROW. No winter road construction information was available at P16S in 2013/14. 
Table 4.5 Annual mean temperatures near the top of permafrost $\left(\mathrm{T}_{\mathrm{TOP}}\right) . \mathrm{NA}=$ not applicable, ND = no data.

\begin{tabular}{lcr}
\hline & \multicolumn{2}{c}{$\begin{array}{c}\text { Annual Mean Temperature } \\
\mathrm{T}_{\text {TOP }}\left({ }^{\circ} \mathrm{C}\right)\end{array}$} \\
\cline { 2 - 3 } & $2012 / 13$ & $2013 / 14$ \\
\hline P11-OFF & NA & ND \\
P11-OFF2 & ND & NA \\
P16S-OFF & -1.8 & -2.1 \\
P16N-OFF & 0.03 & 0.02 \\
P23-OFF & -1.8 & -1.8 \\
P23-OFF2 & ND & -0.1 \\
& & \\
P11-ROW & ND & ND \\
P16S-ROW & -3.4 & -3.5 \\
P16N-ROW & -1.4 & -2.9 \\
P23-ROW & ND & -2.7 \\
\hline
\end{tabular}


Table 4.6 Summary of active-layer freezeback (FB) at the study sites for 2012/13 and 2013/14.

\begin{tabular}{|c|c|c|c|c|c|c|c|c|}
\hline & \multirow{2}{*}{$\begin{array}{l}\text { FB } \\
\text { start }\end{array}$} & \multicolumn{5}{|c|}{ Freezing front passes } & \multirow{2}{*}{$\begin{array}{c}\text { FB } \\
\text { duration } \\
\text { (days) }\end{array}$} & \\
\hline & & $5 \mathrm{~cm}$ & $15 \mathrm{~cm}$ & $30 \mathrm{~cm}$ & $60 \mathrm{~cm}$ & $120 \mathrm{~cm}$ & & \\
\hline & \multicolumn{8}{|c|}{$2012 / 13$} \\
\hline P11-OFF & 10-Oct & - & 11-Nov & - & 29-Mar & - & $>167$ & 1 \\
\hline P16S-OFF & 09-Oct & 22-Oct & 07-Nov & 30-Nov & 27-Dec & 13-Jan & 78 & 2 \\
\hline P16N-OFF & 13-Oct & $30-O c t$ & 20-Nov & 23-Dec & 09-Mar & - & $>150$ & 2,3 \\
\hline P23-OFF & $11-O c t$ & - & 07-Nov & 07-Dec & 14-Jan & 24-Jan & 96 & 2 \\
\hline P11-ROW & 10-Oct & - & 11-Nov & 22-Nov & 26-Dec & 09-Jan & 91 & \\
\hline P16S-ROW & 09-Oct & - & 07-Nov & 16-Nov & 23-Dec & 19-Jan & 101 & \\
\hline P16N-ROW & 13-Oct & - & 08-Dec & 13-Jan & 27-Jan & 22-Feb & 135 & \\
\hline \multirow[t]{2}{*}{ P23-ROW } & $11-$ Oct & - & 19-Nov & 08-Dec & 09-Jan & - & $>90$ & 1 \\
\hline & \multicolumn{8}{|c|}{$2013 / 14$} \\
\hline P11-OFF2 & 14-Oct & 04-Nov & - & 22-Nov & 20-Dec & $13-\mathrm{Feb}$ & 122 & \\
\hline P16S-OFF & 14-Oct & 27-Oct & 01-Nov & 17-Nov & 31-Dec & 14-Jan & 78 & 2 \\
\hline P16N-OFF & 18-Oct & 08-Nov & 08-Nov & 02-Dec & 29-Jan & - & $>103$ & 2,3 \\
\hline P23-OFF & 13-Oct & 03-Nov & 13-Nov & 11-Dec & 13-Jan & 27-Jan & 92 & \\
\hline P23-OFF2 & 13-Oct & 08-Nov & 27-Dec & 19-Feb & 28-Mar & 20-Apr ${ }^{4}$ & 189 & \\
\hline P11-ROW & 14-Oct & 31-Oct & - & - & - & - & - & \\
\hline P16S-ROW & 14-Oct & 01-Nov & 09-Nov & 22-Nov & 24-Dec & 21-Jan & 99 & \\
\hline P16N-ROW & 18 -Oct & - & 17-Nov & 05-Dec & 05-Jan & 04-Feb & 109 & \\
\hline P23-ROW & $14-O c t$ & 01-Dec & 06-Dec & 14-Dec & 20-Dec & 17-Jan & 95 & \\
\hline
\end{tabular}

${ }^{1}$ Bottom sensor did not function so freezeback was greater than specified.

${ }^{2}$ Freezeback duration was calculated to $60 \mathrm{~cm}$ depth, rather than $120 \mathrm{~cm}$ depth.

${ }^{3}$ Temperature at $120 \mathrm{~cm}$ remained near $0{ }^{\circ} \mathrm{C}$ throughout the year.

${ }^{4}$ Depth was $100 \mathrm{~cm}$. 
temperatures stabilized near $0{ }^{\circ} \mathrm{C}$ progressively with time and depth, indicating downward freezing of the active layer. The duration of freezeback ranged from 78 days to more than 150 days and was similar at each site over the two-year study period. The shortest freezeback periods occurred at drier sites with the thinnest active layers. The longest freezeback periods were at the wettest sites. The TCWR practice of snow clearing resulted in earlier freezeback beneath the ROW than off ROW (Figure 4.4, Table 4.6). These results show that the variability in freezeback duration was related to activelayer thickness, moisture content, and winter road practices. The lengthy freezeback period, especially in moisture-rich areas, suggested that the unfrozen portion of the active layer may be hydrologically active well into mid to late winter.

\subsubsection{Modelled freezeback}

Figure 4.5 shows the modelled freezeback at P23, where overflow was observed during the study period. Freezeback was modelled using equation [2-1] and $\mathrm{T}_{\mathrm{s}}$ from P23-AG. A thermal conductivity of $1.1 \mathrm{~W} \mathrm{~m}^{-1}{ }^{\circ} \mathrm{C}^{-1}$, volumetric heat capacity of $1.6 \times 10^{6} \mathrm{~J} \mathrm{~m}^{-3}{ }^{\circ} \mathrm{C}^{-1}$, and volumetric water content of 0.8 was used for the peat (Table 2.1). The modelled freezeback matched well with measured values to depths of $30 \mathrm{~cm}$ indicating that conductive heat transfer describes progression of the freezing front reasonably well in the early part of freezeback (Figure 4.5(c)). The increase in $\mathrm{T}_{\mathrm{s}}$ in early January suggested flooding of overflow water onto the ground surface, which did not affect the ground temperatures at $60 \mathrm{~cm}$ depth (Figure 4.5 (b) and Figure 4.4). This may explain the divergence in the modelled and measured freezeback values at $60 \mathrm{~cm}$ (Figure 4.5 (c)). Between the start of freezeback (October 11, 2012) and end of December, the average 

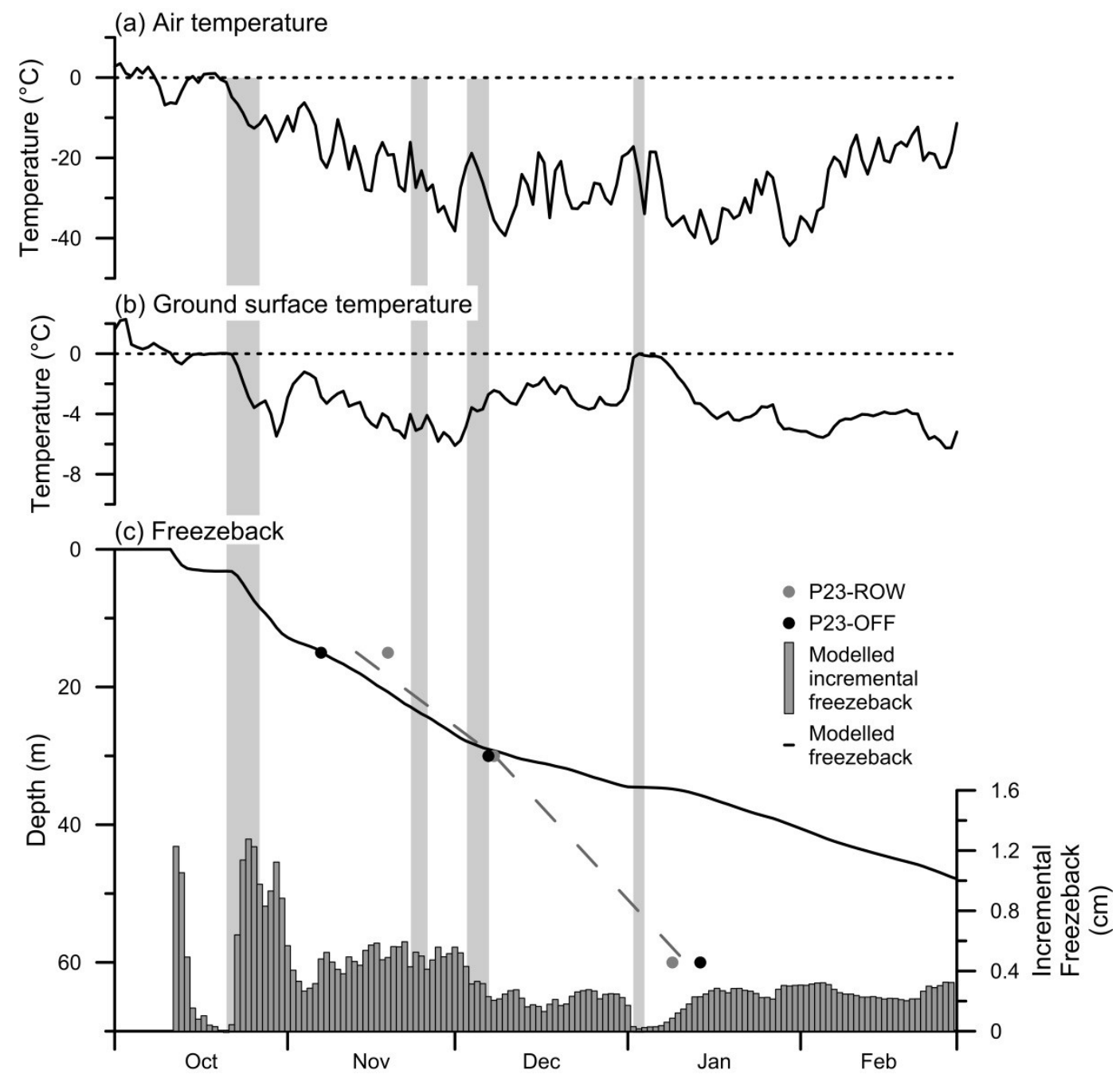

Figure 4.5 (a) Daily mean air temperature and (b) surface temperature at P23 from October 1, 2012 to Feb 28, 2013. (c) Modelled frost penetration with time, modelled incremental daily freezeback, and measured frost penetration at P23-OFF and P23-ROW. Average measured frost penetration is represented by the dashed grey line. Observed overflows are shaded in grey. 
daily rate of frost penetration was $0.4 \mathrm{~cm}(\mathrm{SD}=0.3 \mathrm{~cm})$, ranging from 0 to $1.3 \mathrm{~cm}$, with the higher rate at the beginning of the freezeback season (Figure 4.5 (c)).

\subsubsection{Non-conductive heat transfer}

Figure 4.6 shows the six-hour temperature change, dT, at $15 \mathrm{~cm}$ depth for the 2012/13 freezing season at P16S and P23. Thermal activity is higher $\left(\mathrm{dT} \geq 0.5^{\circ} \mathrm{C}\right)$ during the prefreezing season and again after snow removal on ROW (Figure 4.6 (b)), and lower during the zero-curtain $\left(\mathrm{dT}=0{ }^{\circ} \mathrm{C}\right)$ and under snow cover (Figure $\left.4.6(\mathrm{a}, \mathrm{c}, \mathrm{d})\right)$. Several relatively high-magnitude positive (warming) events occurred during the freezing season that may be indicative of non-conductive heat transfer. January $10^{\text {th }}$ at P16S and January $21^{\text {st }}$ at P23 were associated with winter road flooding operations (Figure $4.6(\mathrm{~b}, \mathrm{~d})$ ). Events in April were associated with snowmelt (Figure $4.6(\mathrm{c}, \mathrm{d})$ ). Four other highmagnitude warming events, between late November and early January, were not associated with the processes mentioned above (Figure $4.6(\mathrm{~d})$ ). These episodic events during the early part of the freezing season may be related to non-conductive heat transfer associated with overflow.

\subsubsection{Thermal regime and freezeback of water bodies}

The daily mean temperatures at about $60 \mathrm{~cm}$ depth in both the watercourse upstream of P23 and near the outlet of P23 Lake for 2013/14 are shown in Figure 4.7. At the start of $\mathrm{FS}_{\mathrm{A}}$, temperatures in the watercourse decreased faster than in the lake following the start of freezeback in the surrounding ground. The watercourse experienced at least two episodic temperature increases, on the order of 0.1 to $0.2^{\circ} \mathrm{C}$, following the start of freezeback in mid-November. The intermittent warming was greater than surrounding ground temperatures and was not associated with air temperature fluctuations. Therefore, 


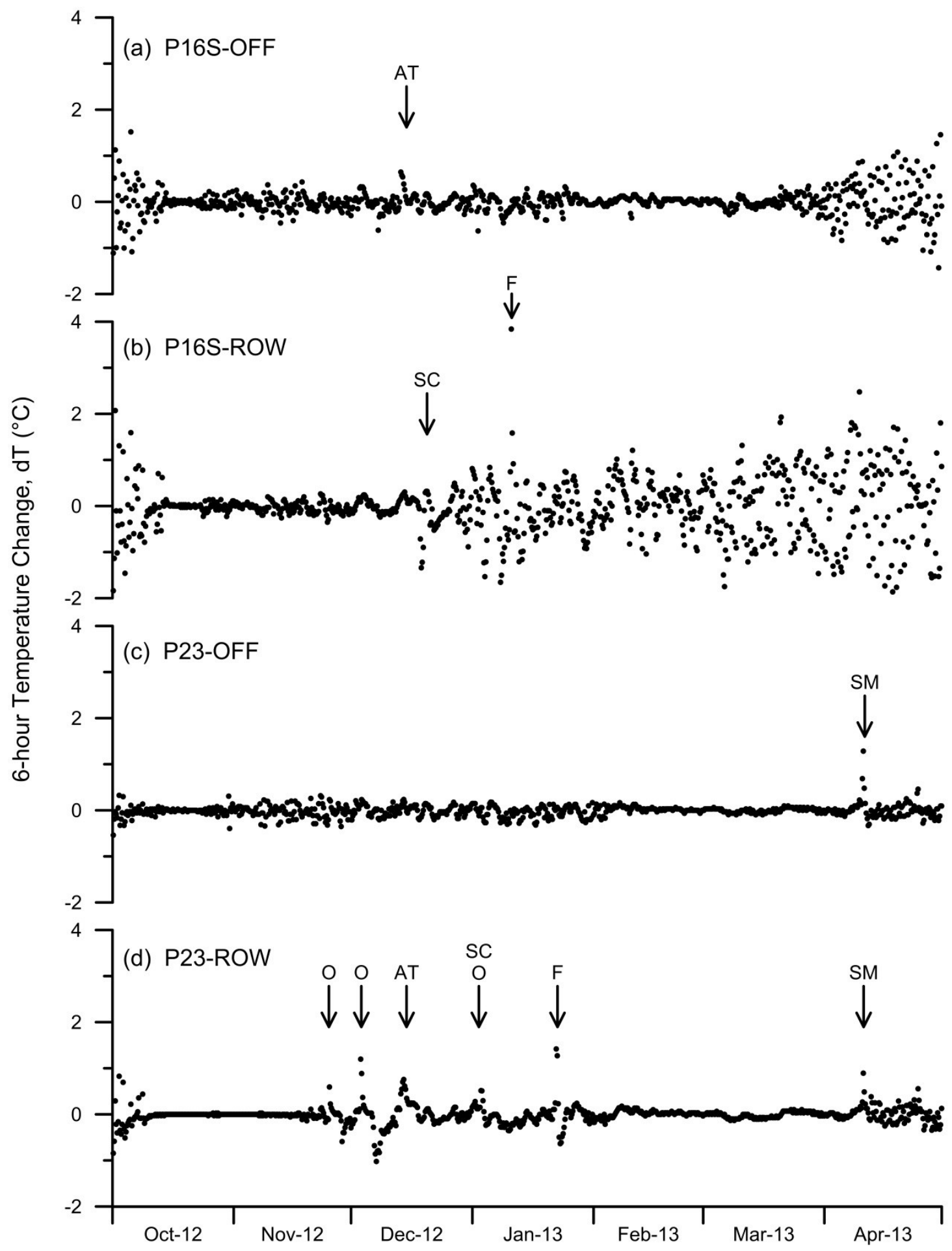

Figure 4.6 Six-hour ground temperature change (dT) at $15 \mathrm{~cm}$ depth off and on ROW at P16S and P23 for 2012/13. Overflows (O), TCWR snow clearing (SC) and flooding (F), and snowmelt (SM) observed in the time-lapse images are noted as well as a spike due to air temperature (AT). 


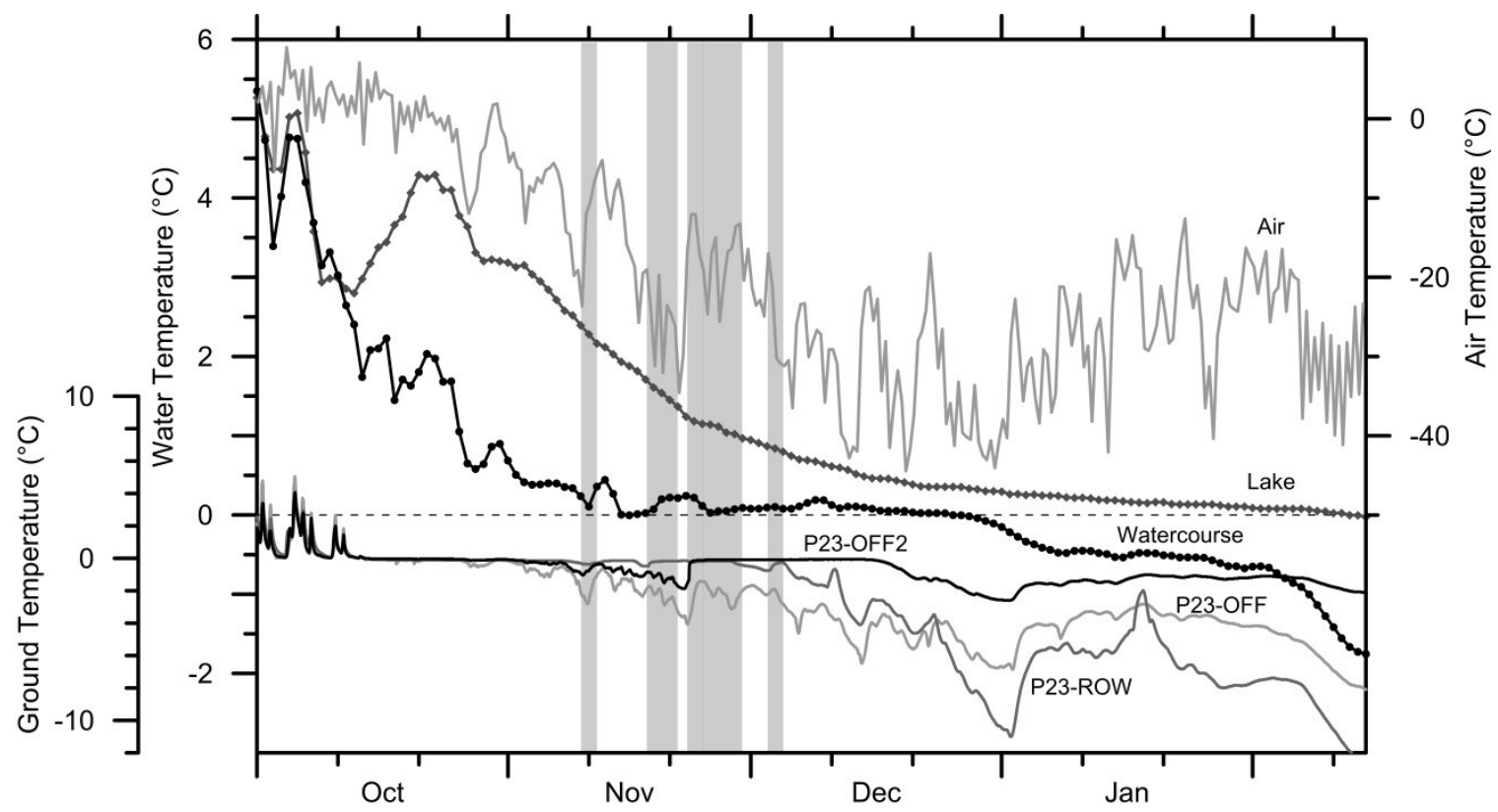

Figure 4.7 Plot of daily mean temperature at about $60 \mathrm{~cm}$ depth in the watercourse and near the lake outlet; air temperature at 6-hr intervals for clarity; and hourly ground surface temperature measured at P23 from October 1, 2013 to February 15, 2014. The shaded boxes represent the observed overflow events. 
the source of the warming was likely water flow from the lake, which was 0.5 to $1{ }^{\circ} \mathrm{C}$ warmer at the time. Freezeback of the watercourse occurred only after the lake outlet started to freezeback in early February. The timing of freezeback of the water bodies suggests that P23 may have been hydrologically connected to P23 Lake well into winter.

\subsection{Active-layer thickness}

The ranges in active-layer thicknesses observed in the field on and off ROW are shown in Figure 4.8. The average active-layer thickness among the portages was less variable on ROW (60 to $84 \mathrm{~cm}$ ) than off ROW (49 to $>125 \mathrm{~cm}$ ). Active layers were thinner in raised bogs (off ROW P16S and P23, 2012/13) than in fens, where active-layer thicknesses also displayed the greatest variability (off ROW P11 and P23, 2013/14). The spatial variability in active-layer thickness suggested fens as preferential areas for water movement during the freezing season, because of a deeper permafrost table and longer freezeback (Table 4.6, section 4.4.1).

\subsection{Field observations of water at portages}

Surface and near-surface water was observed in the autumn and winter at P11, P16N, and P23. In September 2013 and 2014, water was commonly encountered at or above the ground surface in depressions on and off ROW. Water up to $18 \mathrm{~cm}$ deep was flowing on ROW at P16N. Water depths up to $95 \mathrm{~cm}$ were observed off the ROW at P11 and P23, with vegetation that appeared to be floating. P23 had a meandering watercourse that flowed through the fen northeast of the study site and past the instrumentation (Figure 4.9). On ROW, the water in the watercourse was up to $26 \mathrm{~cm}$ deep in September 2013. In contrast, P16S was well-drained on and off ROW with no surface water. The near- 


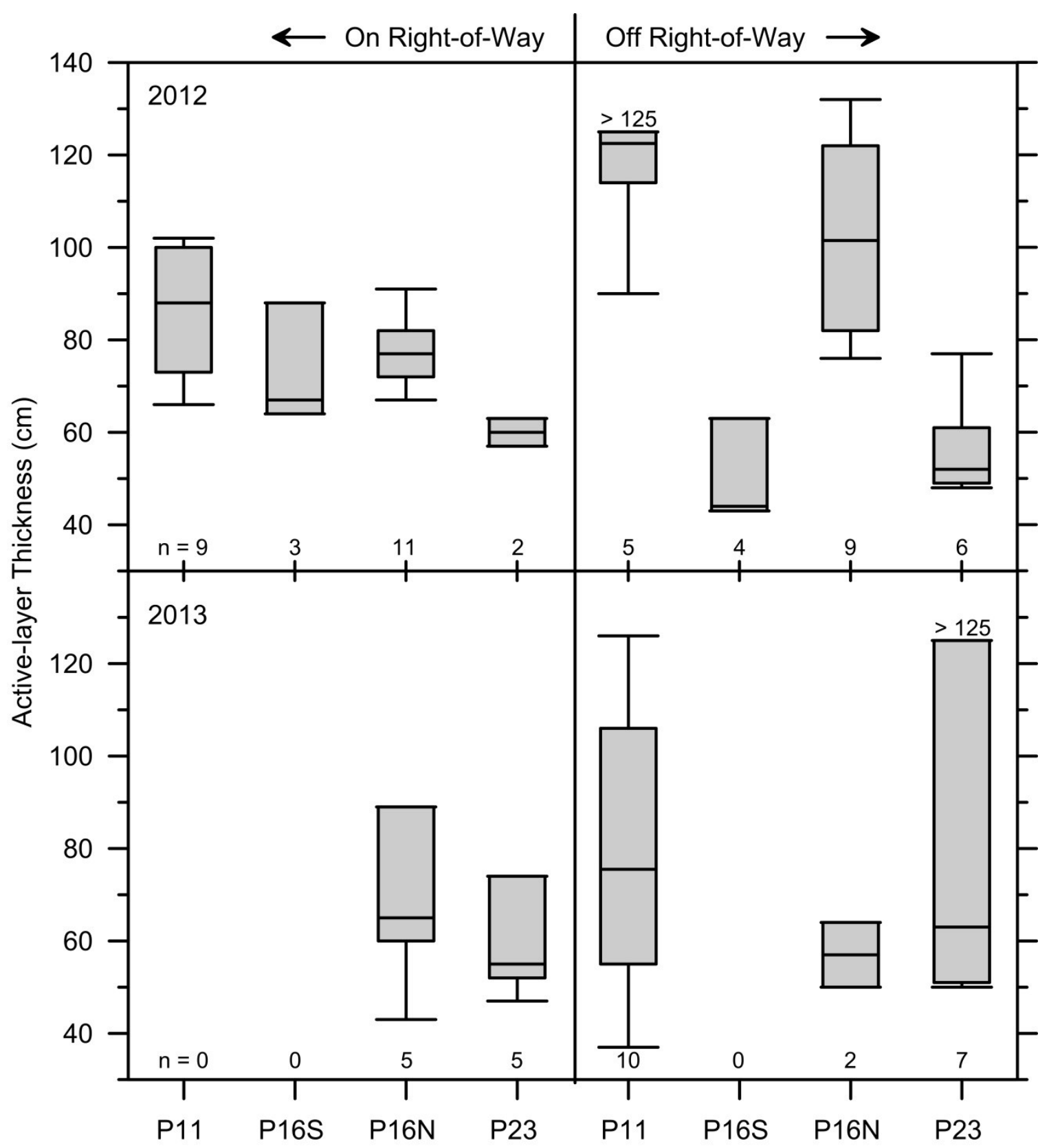

Figure 4.8 Active-layer thicknesses measured at the sites in September 2012 and 2013. Measurements are grouped by year and by location on ROW (left) and off ROW (right). The box and whisker plots present median, minimum, maximum, lower quartile, and upper quartile active-layer thicknesses of $\mathrm{n}$ measurements. 

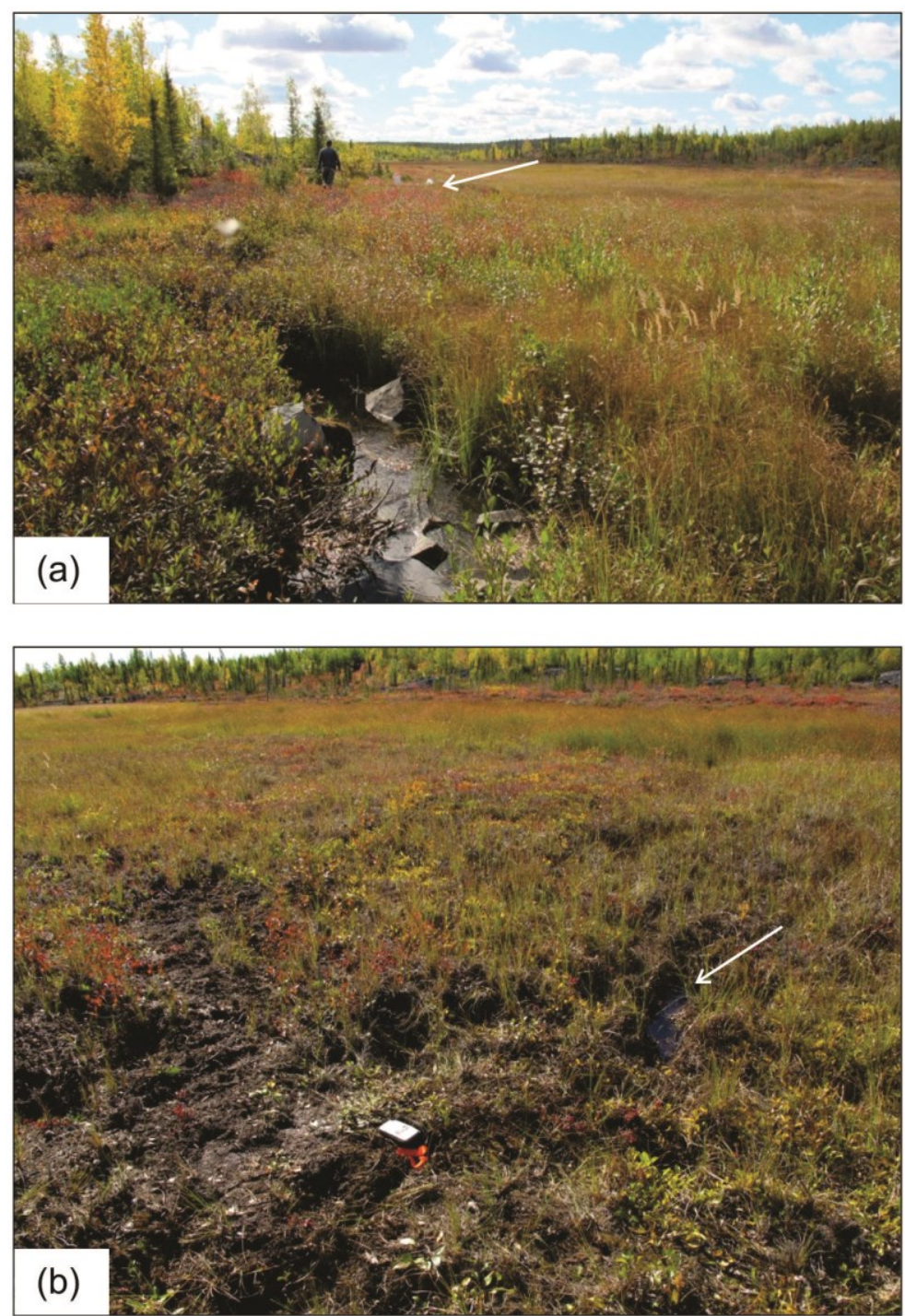

Figure 4.9 Observations of surface water at P23: (a) the watercourse flowing toward the instrument site (denoted by white arrow), (b) surface water (denoted by white arrow) in a depression adjacent to P23-ROW (denoted by the GPS with flagging tape). Photos by W. Sladen (2012). 
surface water at P11, P16N, and P23, suggested the possibility of icings, as opposed to the drier P16S site.

Icings about 20 and $10 \mathrm{~cm}$ thick were observed in the vicinity of P11 and P23, respectively, in February 2014 (Figure 4.10). However, icings were not observed to be actively forming during the February 2013 and 2014 field visits. Water that rose to a centimetre below the ground surface was encountered off ROW at P23 during drilling in February 2014 (Figure 4.10 (a)). The lakes upstream of P11 and P23 were also unfrozen at depth, including near the outlet at P23 Lake, at that time. Therefore, the unfrozen active layer at P23 may have been hydrologically connected to the lake but the hydraulic pressure was insufficient to cause overflow in February 2014.

\subsection{Moisture contents and bulk density}

Gravimetric moisture contents determined on a wet-weight basis (mass of water per unit mass of field-moist soil) for the borehole samples are listed in Table 4.7. Moisture contents for the mineral soil ranged from 3 to $47 \%$. The lowest moisture contents (3$14 \%$ ) were in the road aggregate samples found near the surface at P11 and P16S. The remaining mineral soil moisture contents indicated saturated conditions and, in the case of the frozen clayey silt at P16N, excess ice. The moisture contents for peat were similar among the sites, ranging from 80 to $92 \%$. Based on field observations, the average moisture content of damp peat was $83 \%$ and for saturated peat was $87 \%$. The frozen peat core recovered near P23-OFF2 had a dry bulk density of $0.078 \mathrm{~g} \mathrm{~cm}^{-3}$, moisture content of $92 \%$, and volumetric water content of $86 \%$. These results indicated that aside from the sandy gravel aggregate found at the surface on the ROW, saturated to near-saturated conditions prevailed on and off ROW at all sites. 

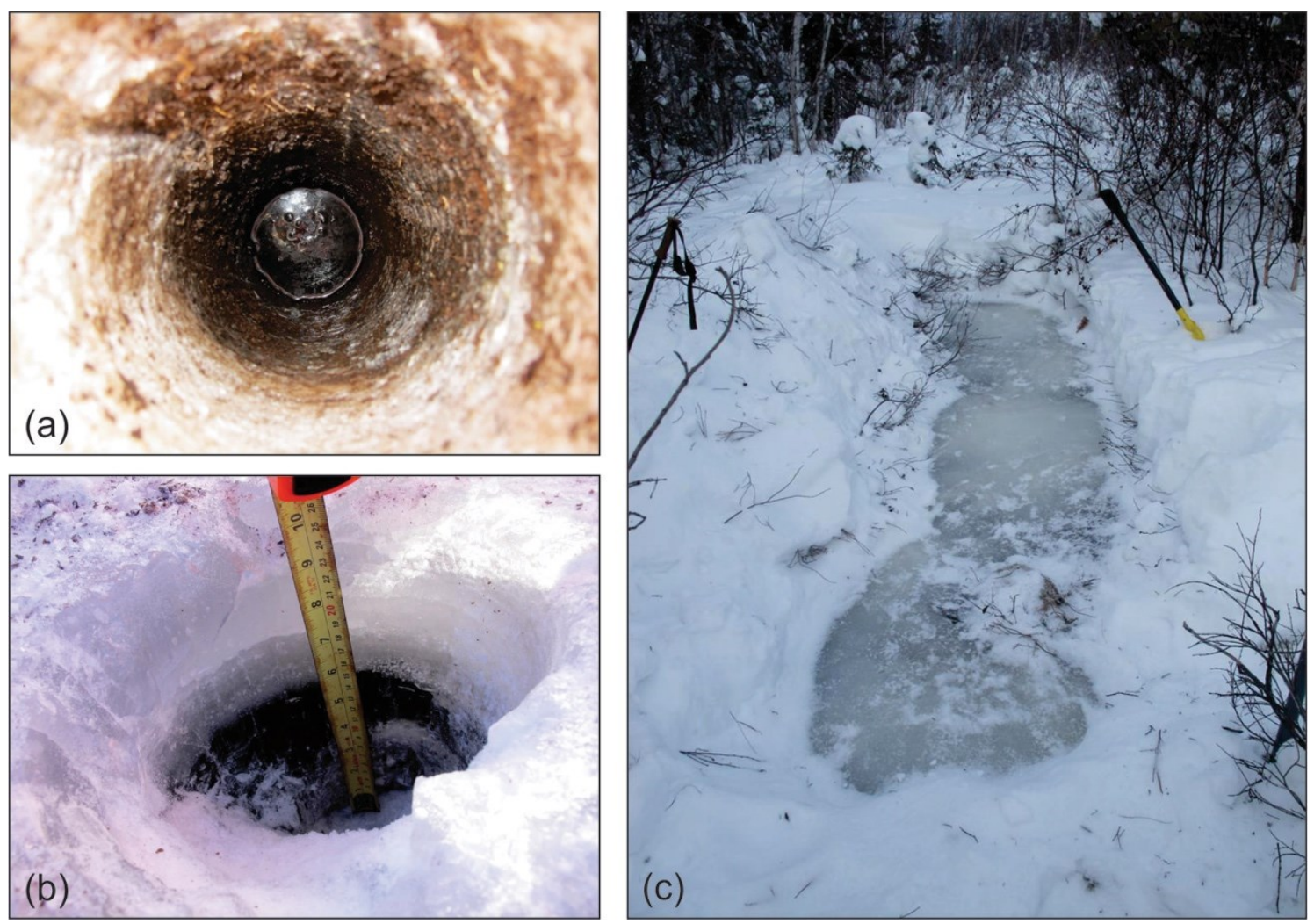

Figure 4.10 Examples of subsurface water and icings in February 2014. (a) Water in the drill hole at P23 that rose to $1 \mathrm{~cm}$ below the ground surface. The icing was $10 \mathrm{~cm}$ thick at this location. (b) White icing ice, $10 \mathrm{~cm}$ thick, over $17 \mathrm{~cm}$ of clear watercourse ice at P23. (c) Partial exposure of icing at P11, icing was $20 \mathrm{~cm}$ thick. Photos by W. Sladen. 
Table 4.7 Summary of borehole sample depths and gravimetric moisture contents (MC) determined on a wet-weight basis for borehole samples. VI = visible ice content; $\mathrm{Vx}=$ visible ice crystals; $\mathrm{Nb}=$ ice bonded, not visible.

\begin{tabular}{lrrrl}
\hline & \multicolumn{2}{c}{ Depth $(\mathrm{cm})$} & MC & \\
Borehole No. & From & To & $(\%)$ & Field Description \\
\hline P11-OFF & 120 & 120 & 14 & Saturated fine sand \\
P11-ROW & 20 & 20 & 11 & Saturated sandy gravel \\
& 78 & 88 & 69 & Frozen peat, trace soil \\
P16S-OFF & 88 & 105 & 25 & Frozen silty sand, ice lenses, VI 30\% \\
& 10 & 40 & 84 & Peat \\
P16S-ROW & 40 & 130 & 87 & Frozen peat \\
& 15 & 15 & 3 & Damp sand and gravel \\
& 29 & 36 & 87 & Damp, fibrous and woody peat \\
& 50 & 58 & 82 & Damp, more decomposed peat \\
P16N-OFF & 88 & 140 & 87 & Frozen peat, very decomposed, Vx \\
& 10 & 70 & 83 & Damp peat, getting wetter with depth \\
P16N-ROW & 79 & - & 91 & Frozen peat \\
& 0 & 75 & 87 & Saturated peat \\
& 80 & 90 & 38 & Saturated silty sand \\
& 100 & 110 & 47 & Frozen clayey silt, VI 10\% \\
P23-OFF2 & 110 & 120 & 44 & Frozen clayey silt, VI 10 \% \\
& 0 & 50 & 80 & Moist to wet peat \\
P23-ROW & 50 & 90 & 84 & Frozen, fibrous peat, roots, Nb \\
& 90 & 130 & 87 & Frozen, fibrous peat, roots, Nb \\
& 0 & 60 & 86 & Saturated fibrous peat, roots, \\
& 60 & 95 & 86 & Frozen peat, Nb \\
& 95 & 120 & 85 & Frozen peat, Nb \\
& 35 & 92 & Frozen peat, VI 30\% \\
& & & &
\end{tabular}




\subsection{Stable isotopes}

The $\delta^{18} \mathrm{O}$ and $\delta^{2} \mathrm{H}$ values for the ice, water, and snow samples collected at portages 11 and 23 are displayed in Figure 4.11. The isotopic data for snow, lake, and near-surface water plotted close to the local meteoric water line (LMWL) (Gibson and Reid 2010). The isotopic composition of the icing ice at P11 and P23 plotted in the same cluster as the Yellowknife summer rainfall and the surface and near-surface waters indicating that overflow, lake and near-surface water were likely from summer precipitation, affected by some evaporation. The $\delta^{18} \mathrm{O}$ difference for the icing ice relative to the nearby lake and active-layer water ranged from 0.6 to $1.5 \%$, indicating rapid freezing in an open system (van Everdingen 1982b). The isotopic results indicated that the icing source was water from the lakes immediately upstream of the icings, originally derived from precipitation.

\subsection{Geochemistry}

The geochemical results from the water and ice samples collected at portages 11 and 23 are shown in Figure 4.12. The chemistry of the local surface water (P11 and P23 lakes) was similar and dominated by $\mathrm{Ca}-\mathrm{Na}-\mathrm{Mg}-\mathrm{Cl}-\mathrm{SO}_{4}$. The relatively high concentration of calcium was likely due to local surficial water/rock interactions (Stotler 2008). The relative ionic concentrations were similar among all samples, but, overall concentrations were lower in the ice samples, probably because of ion expulsion during freezing (Figure 4.12) (van Everdingen 1978, Hallet 1978). The geochemical results agreed with the isotopic data suggesting that the source waters for the overflows were the precipitationderived surface and near-surface waters found directly upstream of the icings. 


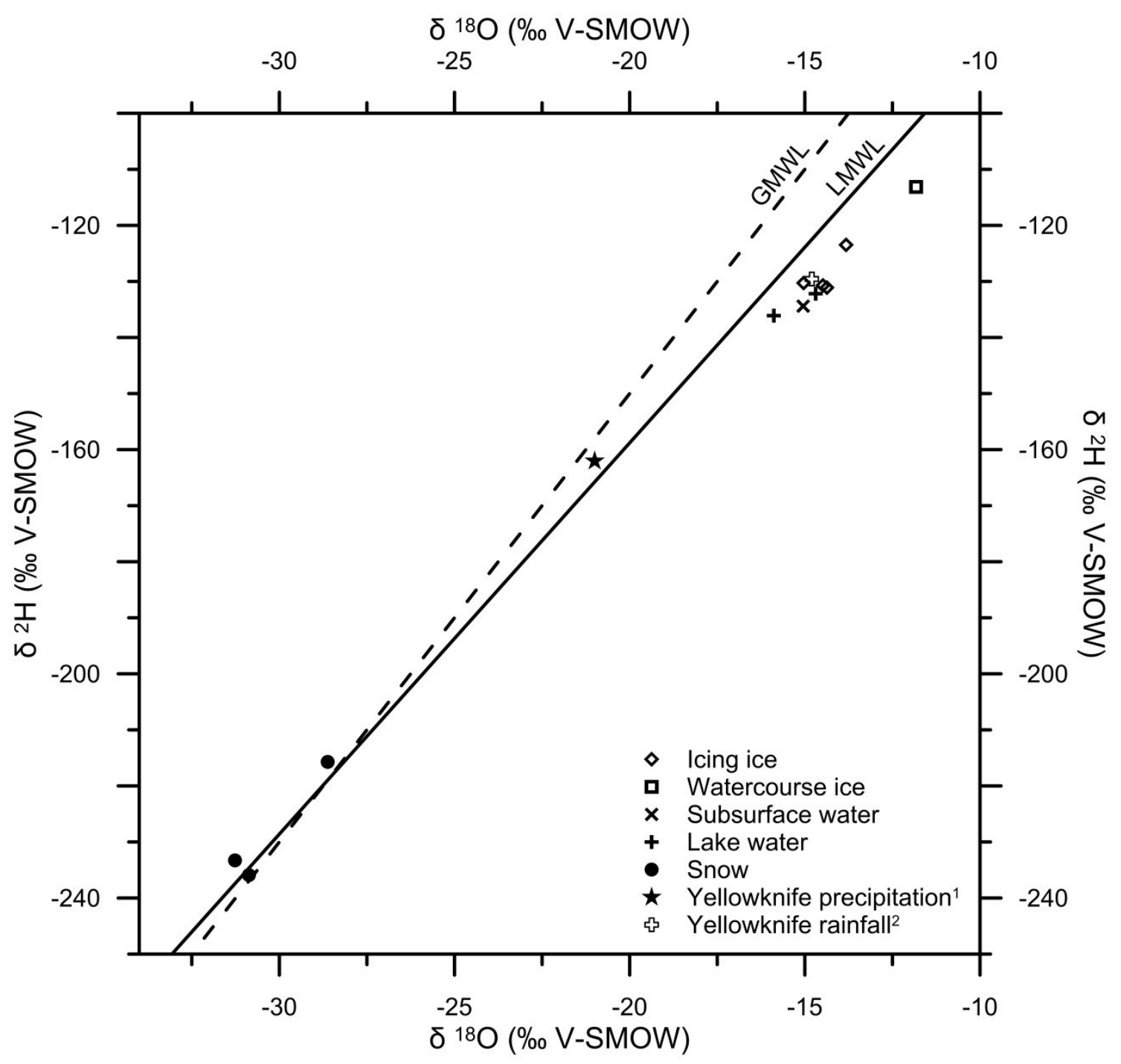

Figure 4.11 Co-isotope plot of samples collected at study sites, P11 and P23, and values reported in Michel (2011) and Gaanderse $(2015)^{2}$ for Yellowknife. GMWL $=$ Global meteoric water line: $\delta^{2} \mathrm{H}=8 \delta^{18} \mathrm{O}+10$ (Craig 1961), LMWL = local meteoric water line: $\delta^{2} \mathrm{H}=6.9 \delta^{18} \mathrm{O}+19.2$ (Gibson and Reid 2010). ${ }^{1}$ Yellowknife precipitation value is an average annual-weighted isotopic composition for the period 1989-1998 (Michel 2011). ${ }^{2}$ Yellowknife rainfall values represent summer isotopic compositions (Gaanderse 2015). 


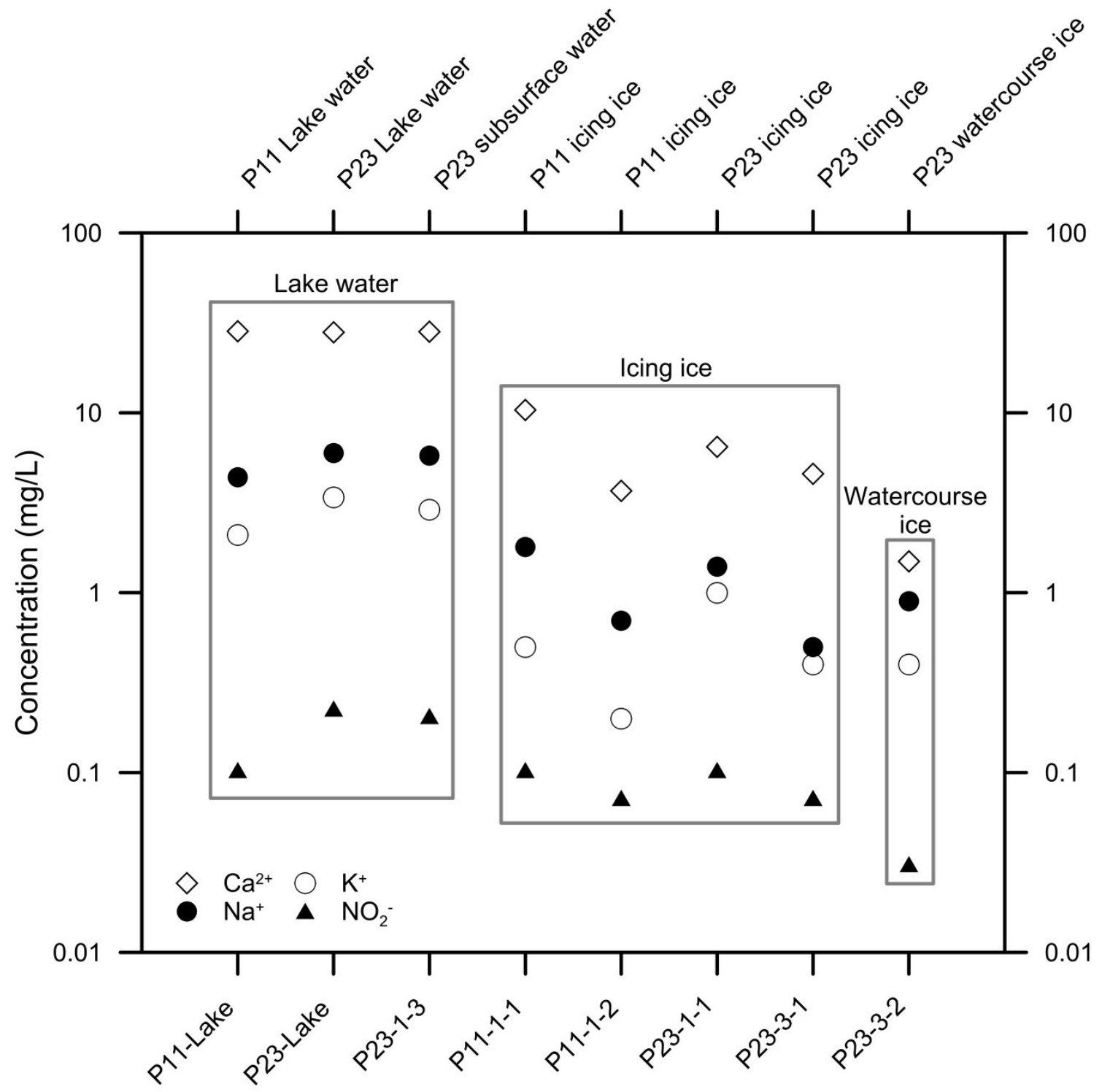

Figure 4.12 Select geochemical data for icing ice, surface and subsurface water at portages 11 and 23. Samples from P11 and P23 were collected on February 17 and 16, 2014, respectively. Ionic composition is similar among samples but concentrations decrease during freezing possibly due to ion expulsion. 


\subsection{Winter road}

Seasonal construction of the TCWR portages consisted of snow clearing and flooding of the ROW. This occurred in sequence from south to north. Table 4.8 shows the timing of the snow clearing and flooding at the study portages during the study period. Winter road construction took place between mid-December and late January in both years. The TCWR was open for freight transport for 60 days (January $30^{\text {th }}$ to March $31^{\text {st }}$ ) each year.

\subsection{Overflows}

Select time-lapse images showing overflows are presented in Figure 4.13. Episodic overflows that appeared to seep onto the surface were observed between October and January during both winter seasons in the time-lapse photography at P23. Table 4.9 summarizes the overflows observed in the photographic record. The events lasted between one and seven days. The period of observed overflow was longer in 2012/13 and the largest observed overflow occurred in December 2012. The overflows commonly initiated at the same location and flowed in the same direction as surface water observed in September (Figure 4.13 (c)). The second camera at P23 captured three events upstream of the first photographs before the lens became covered by snow in 2013/14. The events were closely timed with those recorded on the original camera. Therefore, these events were likely related to the events downstream and may represent the shifting of the overflow outlet or multiple outlets. These observations showed that the overflows at P23 were intermittent, did not evolve from high pressures, as demonstrated by the seep-like nature of flow, and preferentially initiated at the same location. 
Table 4.8 Summary of the TCWR seasonal snow clearing and flooding of the portage sites for the study period. Date represents the first snow clearing and flooding observed in the time-lapse imagery. ND = no data available.

\begin{tabular}{llrr}
\hline \multirow{2}{*}{ Season } & Portage & \multicolumn{2}{c}{ Date } \\
& P11 & Snow cleared & Flooded \\
\hline \multirow{3}{*}{$2012 / 13$} & P16S & 21-Dec & 30-Dec \\
& P16N & 2-Jan & ND \\
& P23 & 2-Jan & 21-Jan \\
\hline \multirow{5}{*}{$2013 / 14$} & P11 & & \\
& P16S & 20-Dec & 30-Dec \\
& P16N & ND & ND \\
& P23 & ND & ND \\
& & 2-Jan & 17-Jan \\
\hline
\end{tabular}



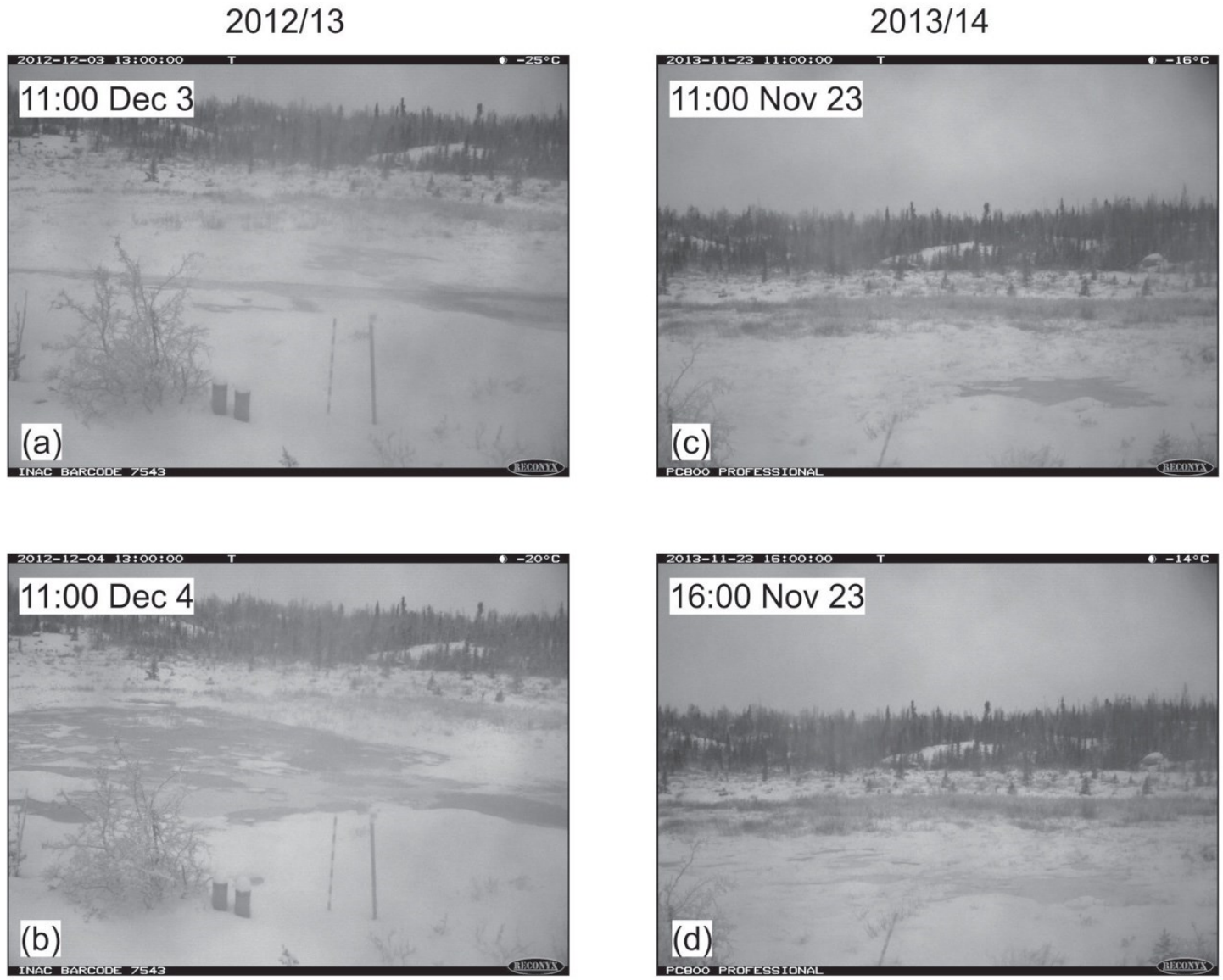

Figure 4.13 Time-lapse photographs of the largest overflow from each season. (a) First image of the December 3, 2012 overflow. (b) Day 2 of the December 3, 2012 overflow. (c) First image of the November 23, 2013 overflow. (d) Extent of November 23, 2013 overflow at the end of the first day. 
Table 4.9 Summary of overflow events observed in the time-lapse photographs at P23. The date and time denote the first image when water was observed on the ground or snow surface, however, the overflow may have started earlier when images were either unavailable or undecipherable. ND = insufficient data.

\begin{tabular}{|c|c|c|c|c|c|}
\hline & Season & Event No. & Start Date & Time & $\begin{array}{c}\text { Duration } \\
\text { (days) }\end{array}$ \\
\hline \multicolumn{6}{|l|}{ Camera 1} \\
\hline & \multirow{4}{*}{$2012 / 13$} & 1 & $2012-10-21$ & $11: 00$ & 7 \\
\hline & & 2 & $2012-11-23$ & $14: 00$ & 4 \\
\hline & & $3^{1}$ & $2012-12-03$ & $11: 00$ & 5 \\
\hline & & 4 & 2013-01-02 & $11: 00$ & 2 \\
\hline & \multirow{5}{*}{$2013 / 14$} & 1 & 2013-11-10 & 9:00 & 2 \\
\hline & & 2 & 2013-11-18 & $10: 00$ & 4 \\
\hline & & $3^{1}$ & $2013-11-23$ & $10: 00$ & 2 \\
\hline & & 4 & $2013-11-25$ & $16: 00$ & 5 \\
\hline & & 5 & 2013-12-03 & $11: 00$ & 2 \\
\hline \multicolumn{6}{|l|}{ Camera 2} \\
\hline & \multirow{3}{*}{$2013 / 14$} & 1 & $2013-11-15$ & 9:00 & 1 \\
\hline & & 2 & 2013-11-17 & $10: 00$ & 5 \\
\hline & & 3 & 2013-11-24 & $11: 00$ & ND \\
\hline
\end{tabular}

${ }^{1}$ The largest observed overflow of the season. 


\subsubsection{Overflows and air and near-surface temperature fluctuations}

Overflows were observed during the first half of the freezing season while air and surface temperatures were generally declining (Figure 4.14 and Figure 4.15). Seventy-eight percent ( 7 of 9 ) of the overflows followed air temperature warming periods that ranged from 1.2 to $16.1{ }^{\circ} \mathrm{C}$ and occurred over $1-4$ days. Ground surface temperature fluctuations preceding overflows ranged from 0 to $3.2^{\circ} \mathrm{C}$ in no consistent direction. Although most overflows followed short periods of air temperature warming, no consistent pattern was determined, including in the ground surface temperatures. The small temperature fluctuations in ground surface temperatures suggested that thermal fluctuations in the ground were not driving overflow.

\subsubsection{Overflows and snowpack development}

Snow pack development relative to the overflow period was similar in both years. The overflow period coincided with accumulation of the snowpack, which was followed by about a month of limited to no snowfall (Figure 4.14 and Figure 4.15). The snowpack thickness at P23 was also similar $(\sim 30 \mathrm{~cm})$ at the end of the overflow periods. Snow accumulation in the 24 to 48 hours preceding the overflows generally ranged from 0 to 4 $\mathrm{cm}$, with the exception of the overflow on November 25, 2013, that followed $8 \mathrm{~cm}$ of accumulation. Therefore, snowfall may be associated with overflow, however, a direct correlation is not clear.

\subsubsection{Overflows and freezeback}

The rate of frost penetration relative to the overflow period is shown in Figure 4.14 and Figure 4.15. Overflows occurred while the ground was freezing back. At the end of the overflow period, freezeback in the overflow area was $<41 \%$ complete in $2012 / 13$ and 


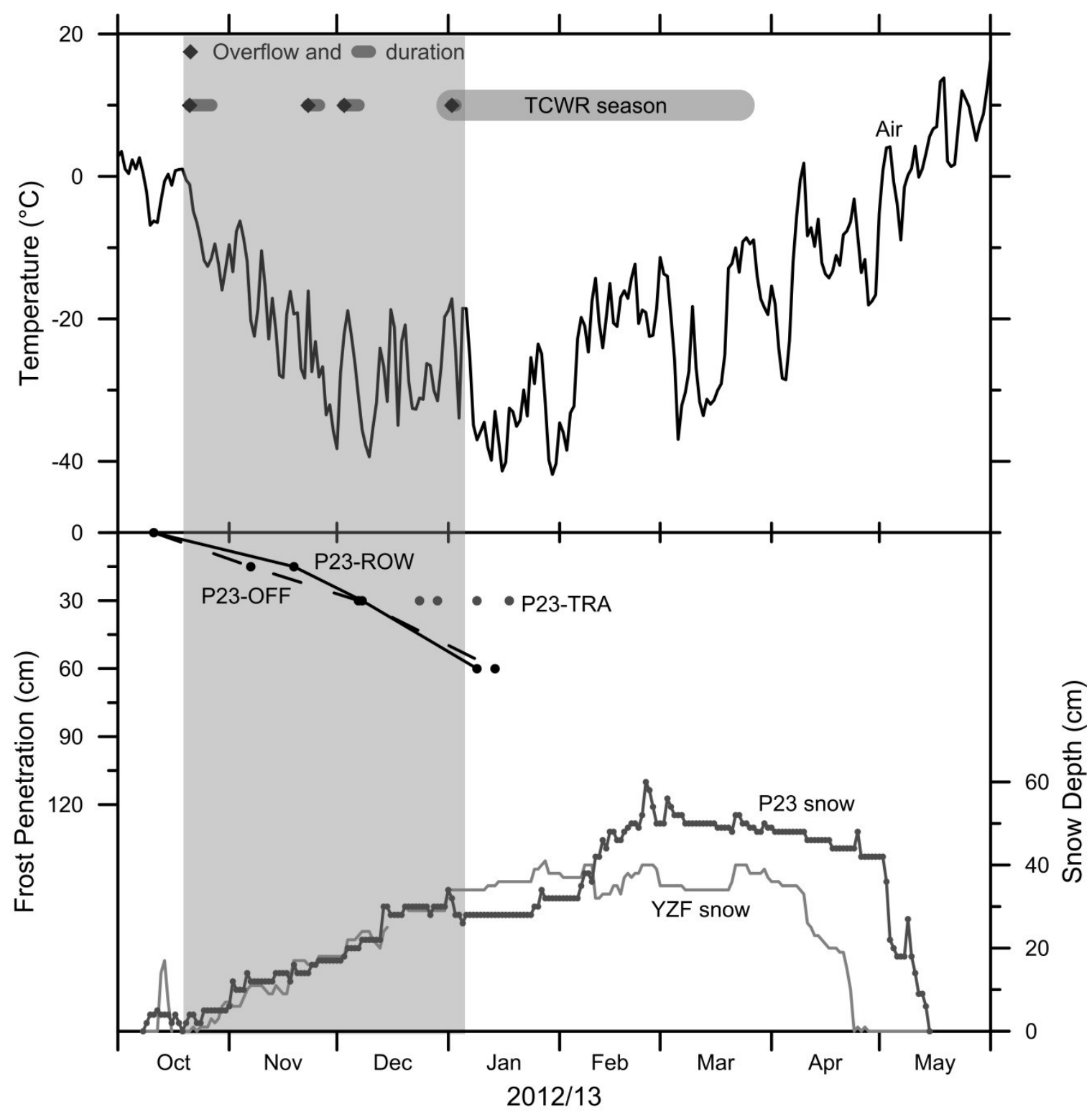

Figure 4.14 Daily mean air temperature, overflow events and duration, snow accumulation, and freezeback at P23 from October 2012 to June 2013. The period of observed overflows is shaded in grey. P23-OFF is located in a raised bog $(\mathrm{FT}=50 \mathrm{~cm})$, P23-ROW is located near the ROW in the overflow-affected area (FT $=57 \mathrm{~cm})$, and P23TRA is the horizontal thermistor string and spans on and off the overflow-affected area $(\mathrm{FT}=58 \mathrm{~cm})$ (Figure 3.6). Frost table (FT) measurements were determined by probing and augering September 7, 2012. Snowfall at Yellowknife Airport (YZF) is included (Environment Canada 2016). 


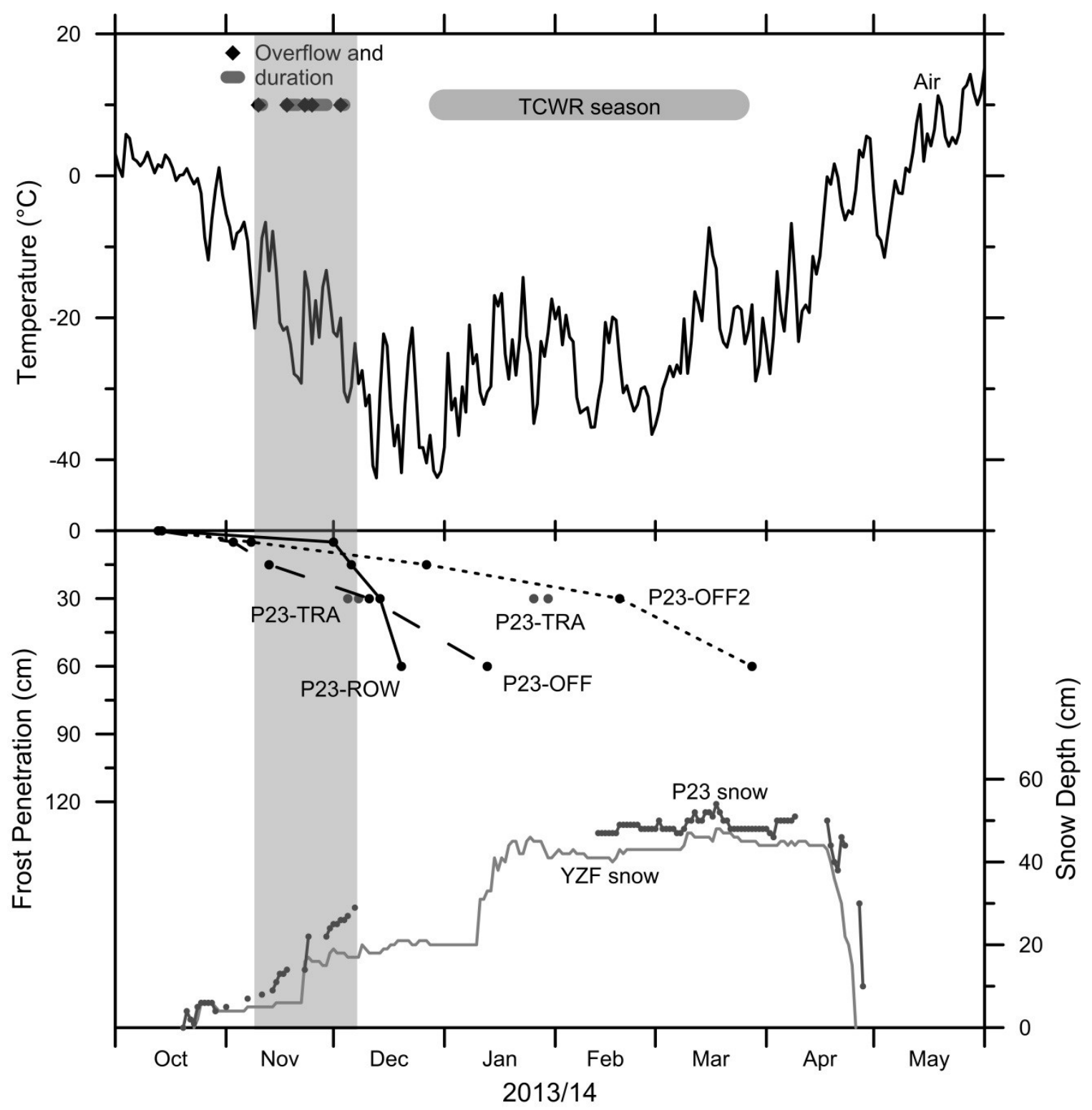

Figure 4.15 Daily mean air temperature at P16S, snow accumulation, overflow events and duration, and freezeback at P23 from October 2013 to June 2014. The period of overflow observations is shaded in grey. P23-OFF is located off ROW in a raised bog, P23-ROW is located near the ROW in the overflow-affected area (FT $=52 \mathrm{~cm}), \mathrm{P} 23-$ TRA is the horizontal thermistor string and spans on and off the overflow-affected area $(\mathrm{FT}=50 \mathrm{~cm})$, and P23-OFF2 is off ROW in the overflow area $(\mathrm{FT}=51 \mathrm{~cm})$ (Figure 3.6). Frost table (FT) measurements were determined by probing and augering September 6, 2013. Snowfall at Yellowknife Airport (YZF) is included (Environment Canada 2016). 
$18 \%$ complete in $2013 / 14$. Freezeback in the surrounding terrain was $83 \%$ and $44 \%$ complete in 2012/13 and 2013/14, respectively. Therefore, freezeback was incomplete with frost penetration in the overflow area about half that of the surrounding terrain at the end of the overflow period in both years.

\subsubsection{Overflows and modelled freezeback}

The October 2012 overflow occurred concurrently with initial frost penetration, while the freezing front was progressing at its most rapid rate $\left(1.2 \mathrm{~cm} \mathrm{day}^{-1}\right)$ (Figure 4.5 (c)). The November and December 2012 overflows also occurred during the period of a relatively high rate of freezeback $\left(0.5 \mathrm{~cm} \mathrm{day}^{-1}\right)$. Figure 4.5 showed that the modelled rate of freezeback did not fluctuate greatly in response to the observed $\mathrm{T}_{\mathrm{a}}$ which agreed with the reduced $\mathrm{T}_{\mathrm{s}}$ observed (Figure 4.5 (a) and (b)).

\subsubsection{Overflows and ground thermal regime}

Overflows produced a signal in the frozen ground thermal regime. The event on December 3-7, 2012, described below was one of the better examples due to its size, photographic documentation, and location relative to the instrumentation. Figure 4.16 shows the ground thermal response recorded at P23-ROW in the area of overflow. Ground temperatures at $15 \mathrm{~cm}$ depth $\left(\mathrm{T}_{15}\right)$ showed a rapid increase of $2.1{ }^{\circ} \mathrm{C}$ between 5:00 December $3^{\text {rd }}$, the timing of the first time-lapse image showing the overflow, and 17:00 on the same day (Figure 4.13 (a)). The six-hour dT at the same depth suggested that this increase in temperature was likely due to non-conductive heat transfer from the overflow water (Figure 4.6 (d)) (Kane et al. 2010). After 17:00, $\mathrm{T}_{15}$ continued to increase but at a slower rate as it approached $0{ }^{\circ} \mathrm{C}$. After 11:00 December $6^{\text {th }}, \mathrm{T}_{15}$ decreased rapidly, suggesting that the overflow water had frozen back by December $6^{\text {th }}$ and the 


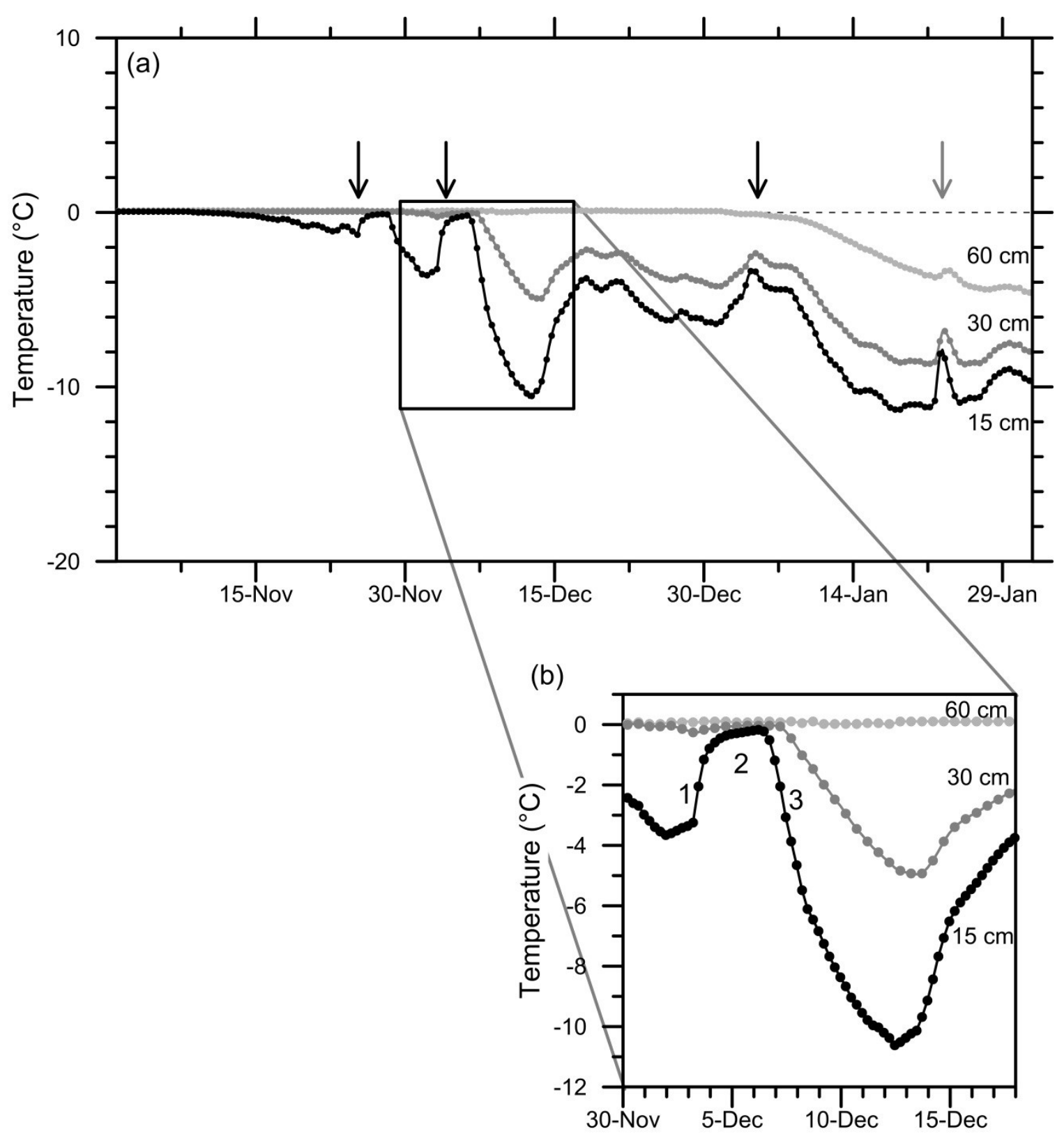

Figure 4.16 (a) Ground temperature record at 15, 30, and $60 \mathrm{~cm}$ depth at P23-ROW from November 1, 2013 to January 31, 2014. Black arrows mark the date of overflows; the grey arrow marks the TCWR flooding of the road. (b) The three-stage ground thermal signal in response to the December 3-7 overflow: (1) temperature increase due to flooding of overflow water; (2) temperature remains near $0{ }^{\circ} \mathrm{C}$ as overflow water freezes and latent heat is released; and (3) ground temperatures decrease rapidly due to bare ice surface. 
rapid cooling was associated with the change in ground surface conditions, from insulating snow cover to a thermally conductive bare ice surface. Migration of the overflow outlet was observed in the time-lapse imagery during this event.

This example illustrated the three-phase thermal signal in the frozen ground produced by an overflow, related to (1) warming from flooding by overflow water, followed by (2) the release of latent heat as the overflow water freezes, and (3) a rapid decline in ground temperatures due to high thermal conductivity of the bare ice surface. The episodic nature of the thermal signals indicated that the overflows were intermittent.

\subsubsection{Overflows and source water}

The isotopic and geochemical results indicated that the overflow source water was from precipitation-derived surface waters found in the upstream lakes (Figure 4.11 and Figure 4.12). The timing of freezeback of the watercourse and lake outlet suggested that the unfrozen active layer was hydrologically connected to the source during the overflow period (Figure 4.7). The timing of freezeback at the lake outlet and P23-OFF2 (Figure 4.7 and Figure 4.15), suggested lateral heat transfer between the lake and P23 through much of the winter. These results illustrate that during the overflow period, the hydraulic pressures leading to overflow developed in an open system.

\subsubsection{Overflows and rainfall}

Seasonal rainfall recorded at YZF for the study period is shown in Table 4.10. Summer (Jul - Aug) and autumn (Sep - Oct) rainfall were greater in 2012/13 than in 2013/14. This related positively to the greater observed overflow period duration and spatial extent in 2012/13. This evidence supports the link between rainfall-derived water and overflow. 
Table 4.10 Total seasonal rainfall recorded at Yellowknife Airport (Environment Canada 2016) and period of observed overflow duration at P23 for 2012/13 and 2013/14.

\begin{tabular}{lrr}
\hline & $2012 / 13$ & $2013 / 14$ \\
\hline Rainfall (mm) & & \\
July - August & 59.2 & 27.2 \\
September - October & 68.2 & 33.0 \\
July - October & 127.4 & 60.2 \\
& & \\
Overflow period (days) & 74 & 25 \\
\hline
\end{tabular}




\subsubsection{Overflows and Tibbitt to Contwoyto Winter Road}

The majority of the overflows observed in this study occurred before seasonal construction and operation of the TCWR. The exception was the overflow on January 2, 2013, that occurred after snow clearing but before flooding at P23 (Table 4.8, Figure 4.14, and Figure 4.15). Therefore, the seasonal TCWR practices were not observed to cause overflow during the study period.

\subsection{Historical overflows}

Figure 4.17 shows the number of days that water issues were reported on the TCWR portages from 2005/06 to 2012/13. Over the eight-year record, most of the overflows occurred at portages 11 and 23 while $30 \%$ occurred at other portages. Winters 2005/06 and 2012/13 had the greatest number of days with water issues, followed by 2009/10. The TCWR log entries suggested considerable overflow occurred during February 2006 and February 2013. Portages 11 and 23 displayed similar overflow activity over time, suggesting that the conditions conducive to icings may have been similar at these portages.

\subsubsection{Historical overflows and air temperature fluctuations}

As with the study period overflows, most of the events $(62 \%)$ were proceeded by warming periods, which ranged from 0.7 to $17.7^{\circ} \mathrm{C}\left(\overline{\mathrm{x}}=5.6^{\circ} \mathrm{C}, \mathrm{SD}=5.1^{\circ} \mathrm{C}, \mathrm{n}=16\right)$. The range in cooling was similarly variable, ranging from 0.6 to $26.9^{\circ} \mathrm{C}\left(\overline{\mathrm{x}}=8.4{ }^{\circ} \mathrm{C}, \mathrm{SD}\right.$ $\left.=8.2^{\circ} \mathrm{C}, \mathrm{n}=10\right)$. Therefore, while warming periods may be important, they were not categorically associated with overflows. 

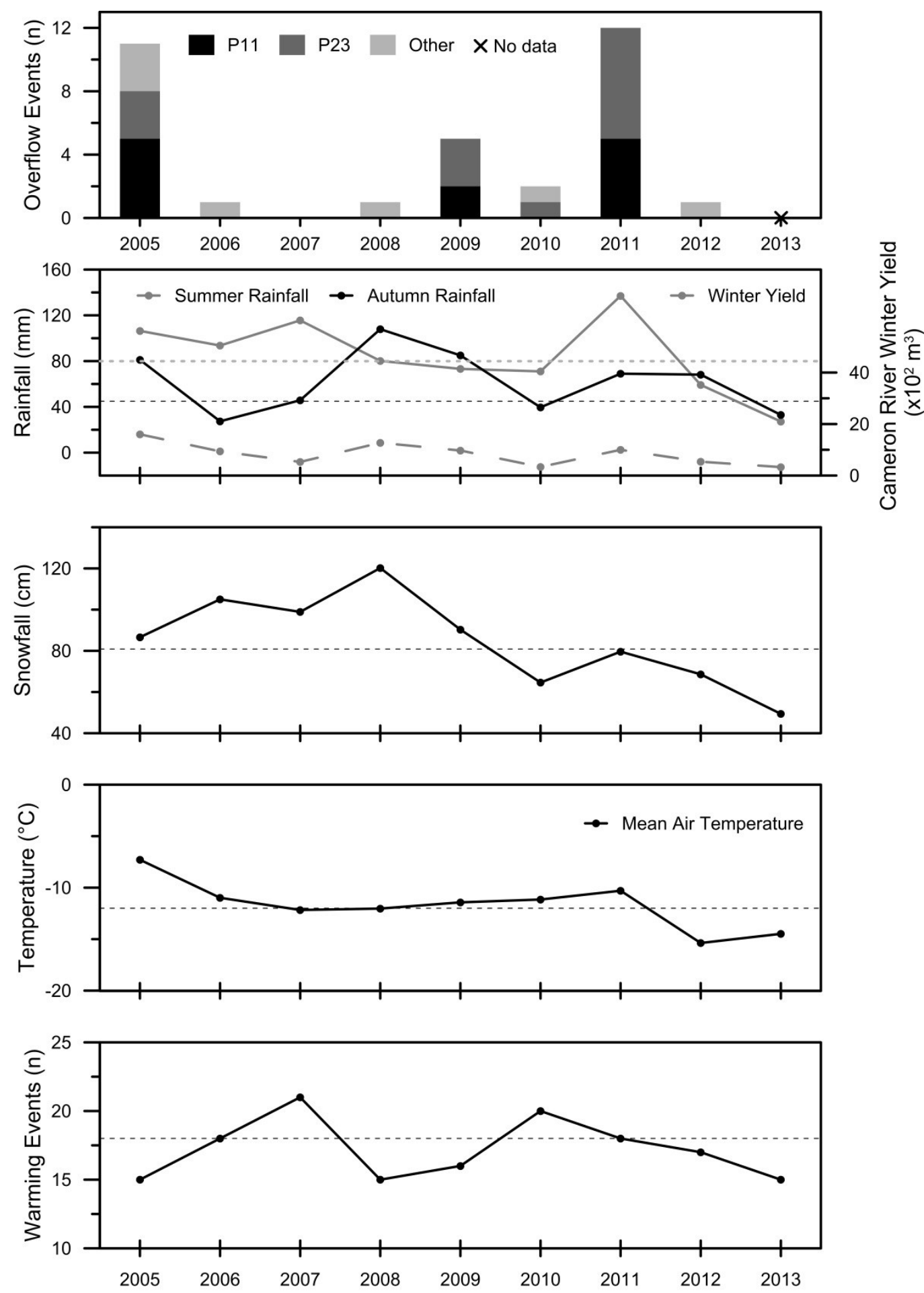

Figure 4.17 Plots of overflow history $(2005 / 06$ - 2013/14) for the southern portion of the TCWR and period weather: summer rainfall (Jul-Aug); autumn rainfall (Sep-Oct); snowfall (Oct-Dec); mean air temperature (Oct-Dec); and warming periods $\geq 5^{\circ} \mathrm{C}$ (OctFeb) for Yellowknife Airport. The Cameron River winter yield (Nov-Mar) is also included (Environment Canada 2016, 2017). Overflow events are distinguished between P11, P23, and other portages. The 1981-2010 normals are denoted by the dashed lines. 


\subsubsection{Historical overflows and seasonal meteorological variables}

Figure 4.17 shows the Yellowknife summer rainfall (Jul-Aug), autumn rainfall (Sep-Oct), early winter snowfall (Oct-Dec), early winter mean air temperatures (Oct-Dec), and warming periods $\geq 5^{\circ} \mathrm{C}$ (Oct-Feb) for the TCWR overflow record. Due to the length of the record, a statistical relation between these variables and overflows could not be identified. However, it was clear from scatter plots of annual overflow count and each variable described above that no one variable had a strong relation with overflow (not shown). Increased overflow activity at portages 11 and 23 coincided with a combination of above average autumn rainfall, above average early winter mean air temperature, and average early winter snowfall (Figure 4.17). While warming seemed associated, but not categorically, with overflows on an event-by-event basis, the frequency of warming events $\geq 5^{\circ} \mathrm{C}$ showed no relation with high overflow years. No pattern was observed between the overflows at other portages and any one or combination of meteorological variables due to the singularity of their occurrence. The eight-year TCWR record illustrates that overflows at some sites appear to be driven by a similar combination of meteorological variables, but not other sites, suggesting the influence of site-specific factors on overflow.

\subsection{Summary}

Episodic overflows that appeared to seep onto the surface occurred during the first half of freezeback in the overflow area during the two-year study. Overflows produced a thermal signal in the frozen ground due to flooding by the overflow water, release of latent heat as the water froze, and rapid cooling of ground temperatures from a change in ground surface conditions. The overflows were fed by local surface water found in lakes 
directly upstream. Overflow periods occurred prior to, and therefore not coincident with, the operation of the TCWR. Overflow period duration was positively related to summer and autumn rainfall. The eight-year TCWR record indicated that the most active overflow sites coincided with years of above average autumn rainfall and early winter mean air temperature, and average early winter snowfall. Overflows at other sites in other years showed no relation to any combination of meteorological variables suggesting the influence of site-specific factors. 


\section{Chapter: DISCUSSION}

\subsection{Introduction}

In Chapter 4, the timing and duration of overflows and associated air, ground and water body temperatures, rainfall, snowpack, freezeback, and winter road conditions were examined. This chapter discusses the field and historical overflow observations in more detail by (1) outlining key observations; (2) discussing several factors controlling icings; and (3) placing this study's observations within the context of the Great Slave Uplands region (GSU) and past and future climate.

\subsection{Field observations of overflows}

The source for the overflows is suprapermafrost groundwater from precipitation-derived surface waters upstream of the icings. This is apparent from the isotopic and geochemical data shown in Figure 4.11 and Figure 4.12. The similar ionic concentrations in the icing ice and surface and near-surface waters show that the sources have the same chemistry (Figure 4.12). The lower concentrations in the ice are probably due to ionic expulsion during freezing of the overflow water (Hallet 1978). The $\delta^{18} \mathrm{O}$ and $\delta^{2} \mathrm{H}$ values for the icing ice samples plot in a cluster with the lake and near-surface water samples, as well as Yellowknife summer precipitation (Figure 4.11). These results support the geochemical data and indicate that the icing ice and lake and near-surface waters are of the same origin. The cluster of $\delta^{18} \mathrm{O}$ and $\delta^{2} \mathrm{H}$ values relative to the local meteoric water line (Gibson and Reid 2010) indicates that the lake and active-layer water are predominantly derived from summer precipitation that has been exposed to some evaporation (Gibson et al. 1993), indicating the importance of seasonal rainfall and lake levels prior to the freezing season on overflow activity. 
Episodic overflows occur during the first half of freezeback in the overflow area. Time-lapse photographs recorded periodic overflows after the ground started to freeze in 2012/13 and 2013/14 (Figure 4.14 and Figure 4.15) and no overflows were observed after early January in either winter. Freezeback in the overflow area was $<41 \%$ completed by the time the overflow period ended in 2012/13 and about 18\% completed in 2013/14. Therefore, it is not necessary for the active layer to freeze entirely before overflow ceases. Rather the end of the overflow period may be related to the water supply as was observed in late winter when hydraulic pressures were insufficient to cause overflow.

Overflows are an intermittent process. Individual overflow events lasted $2-7$ days and were separated by between 1 and 26 days, during which time the ground surface froze (Table 4.9 and Figure 4.16). The periodic nature of the overflows is also reflected in the frozen ground by a three-phase thermal signal: first, an increase in ground temperatures due to flooding of overflow water; second, stabilization of ground temperatures near $0{ }^{\circ} \mathrm{C}$ while the overflow water freezes and latent heat is released; and third, rapid cooling of ground once the overflow had frozen (Figure 4.16). Intermittent warming in the watercourse during cooling implies fluctuations in water flow during the period of observed overflows (Figure 4.7). Watercourse warming exceeded surrounding ground temperatures, indicating that the source of "warming" was water from the lake. Watercourse warming likely resulted from periodic increases in flow.

Overflows occur in an open system. The watercourse and the lake outlet upstream of P23 were unfrozen during and after the 2013/14 overflow period (Figure 4.7), indicating that the water in the unfrozen portion of the active layer was hydrologically connected to the lake during this time. The overflow water appeared to 
seep onto the surface via subsurface pathways rather than flow under high pressure as may be expected in closed-system freezing. The pressures leading to the icings observed in this study develop in an unconfined system and are not caused by pore-water expulsion in a closed system as in other hydrological processes that produce features such as pingos and perennial frost mounds (Mackay 1977, Hinkel et al. 1996, Morse and Burn 2014).

\subsection{Historical TCWR overflow observations}

There were no consistent observations of overflows in the mid to late winter in the TCWR long-term record. Figure 4.17 shows overflows, summer and autumn rainfall, Cameron River winter yield, early winter snowfall and mean air temperature, and number of warming periods for the eight-year record. Portages 11 and 23 experienced overflows in the same years indicating that the driving factors operating at these portages may be similar. The active overflow years at these portages are associated with higher than normal autumn rainfall, above normal early winter mean air temperature, and normal early winter snowfall. The occurrence of any one or two of these factors did not lead to overflows at these portages. Overflows that occurred at other portages in other years are not easily associated with any combination of meteorological variables and indicate a divergence in driving factors, likely site-specific environmental factors, from those associated with portages 11 and 23 .

\subsection{Research hypotheses revisited}

The hypotheses tested in this thesis were: (1) freezeback of the ground beneath the winter road causes icings along the TCWR; (2) the timing of overflows in the Great Slave Uplands is related to air temperature fluctuations; and (3) the temporal extent of overflow occurrence is limited by the depth of the freezeback. 
The icings observed in this study formed and ceased being active before the active layer froze back on (and off) the ROW. Therefore, freezeback beneath the winter road was not observed to cause icings during this study. Moreover, the TCWR records indicated that in the active icing years overflow was an issue at the start of the operating season, which from observations in this study occurs before freezeback is completed.

The timing of overflows was not observed to be categorically related to air temperature fluctuations. No consistent trend in either warming or cooling was observed to precede the observed overflows.

The temporal extent of overflow occurrence was not observed to be limited by the depth of freezeback. The depth of the freezing front at the end of the observed overflow period differed from year to year as well as spatially.

Icing activity is influenced by multiple environmental factors, but in the GSU, water supply is a major control. The variability in water supply associated with the threshold-mediated hydrologic regime likely had a stronger effect on icing behaviour than active-layer freezeback (hypotheses 1 and 3) and air temperature (hypothesis 2). Other factors, such as snowcover, varied over the overflow period and may have moderated the influence of freezeback and air temperature at the event and seasonal scales. None of the hypotheses adopted at the beginning of the study (see p. 8) were supported by the field results. 


\subsection{Factors controlling overflows along the TCWR}

\subsubsection{Basin water balance}

In the threshold-mediated flow system of the subarctic Canadian Shield, the majority of winter flow is generated from water stored in lakes (Spence et al. 2014). This is supported by the results from the geochemical analysis of water samples (Figure 4.12). The flow from a singular basin or lake within a chain of basins depends on its unique water balance, which is a function of lateral and upstream inflow, precipitation, snowmelt, evapotranspiration, and outflow (Woo and Mielko 2008). Outflow occurs when storage exceeds the basin capacity or threshold, so flow connectivity within a chain of lakes is often not continuous in the subarctic Shield. Winter baseflow in the northern Shield is positively related to autumn rainfall (Spence et al. 2011), which is an important factor driving overflow. This is supported by the isotopic results that show the source for the icings is precipitation-derived surface and near-surface waters (Figure 4.11). The positive relation between autumn rainfall and overflow extent, both spatial and temporal, observed in this study (Table 4.10 and Figure 4.17) and observations by Spence et al. $(2011,2014)$ support the significant correlation between icing activity and autumn rainfall determined statistically by Morse and Wolfe (2015) for the GSU. The ability of autumn rainfall to generate surface and subsurface flow from an individual lake is moderated by individual basin water balance which is a function of the catchment area and antecedent conditions. In turn, these depend on the water balance of past seasons as well as the current season (Spence and Woo 2003, Spence and Woo 2006, Woo and Mielko 2008). This partly explains why not all the years in the TCWR record with above average autumn rainfall were associated with high overflow activity (Figure 4.17). 
The intermittent flow associated with threshold-mediated drainage contrasts with the hydrological systems associated with many of the studies on icings in central and northern Alaska (e.g. Kane 1981, Yoshikawa et al. 2007) and other parts of northern Canada (van Everdingen 1978, 1982a, 1982b, Veillette and Thomas 1979), which are predominantly fed by perennial springs. The decrease in baseflow as the winter progresses due to recharge being stored on the surface as snow (Kane et al. 1973) and the threshold-mediated drainage suggests that the overflow period in the subarctic Canadian Shield may be shorter and produce less extensive icings than in a perennially spring-fed system (Pollard and van Everdingen 1992). Therefore, supply-limited basin water balance is an important factor controlling overflow in the GSU.

\subsubsection{Freezeback}

The first half of freezeback is important for overflows. The observed overflows occurred periodically while the active layer was freezing in 2012/13 and 2013/14, as previously noted in both permafrost (e.g., Kane 1981) and non-permafrost environments (e.g., Price and Fitzgibbon 1987). This timing agrees with the accepted mechanism for icing generation, whereby overflow results from increases in hydraulic potential as water movement in the active layer becomes restricted by the reduced cross-sectional area of unfrozen ground (van Everdingen 1978, Pollard and French 1984).

The early part of freezeback is especially important in fens because it involves freezing of the upper portion of the active layer. In a saturated peat environment, subsurface water flow is concentrated in the upper, less decomposed peat layer $(10-20$ $\mathrm{cm}$ ) where the ground is about three orders of magnitude more hydraulically conductive (Price and FitzGibbon 1987, Quinton et.al. 2008). Thus, freezing of the upper peat layer 
significantly affects the hydraulic transmissivity of the active layer, impounding drainage upstream and causing an increase in hydraulic potential (Burn 1995).

Variability in freezeback has implications for water flow. Ground subject to overflow experiences a temporary increase in freezeback rate after the overflow has frozen and before the ice surface is covered with snow (Figure 4.16). This may lead to spatial shifting of the overflow outlet as water under hydraulic pressure is forced through a zone of lower resistance, as was observed during the overflow of December 3-7, 2012. In the overflow area, the frost depth was about half that of the surrounding terrain at the end of the overflow period in both years. The slower rate of freezeback was likely due to advective heat transfer by lateral water movement at depth (van Everdingen 1982b, Carey and Woo 2005). This is important for winter drainage as it maintains a subsurface flow channel and hydrological connectivity within the basin (Price 1983, Spence et al. 2014). Complete freezeback would shut off the subsurface water flow and effectively end icing development.

\subsubsection{Air temperature fluctuations}

Air temperature fluctuations as a controlling variable for icings have been suggested by several authors, e.g., Kane (1981) and Yoshikawa et al. (2007). The frequency of subfreezing warming periods has been statistically related to icing activity in central Alaska (Yoshikawa et al. 1999) and in the Great Slave Uplands (Morse and Wolfe 2015). Cooling has been associated with a decrease in pore-water pressure (Kane and Carlson 1977) and intermittent flow (van Everdingen 1982a). Kane and Carlson (1973) reported that pore-water pressures decrease during cold periods. Similarly, van Everdingen 
(1982a) noted a diurnal behaviour in flow where it slowed at night and reactivated during the day.

An association between overflow and air temperature was not observed categorically in this study. While the majority of overflows observed in this study (7 of 9) and in the TCWR record (16 of 27) followed periods of warming, the amount of warming was generally less than that determined by Yoshikawa et al. (1999) (about 15 $\left.{ }^{\circ} \mathrm{C}\right)$ and by Morse and Wolfe $(2015)\left(\geq 5^{\circ} \mathrm{C}\right)$, and in some cases overflows were not preceded by warming at all. In addition, air temperature fluctuations occurred that were not followed by overflows. Near-surface ground temperature fluctuations associated with the air temperature were on a much smaller scale $\left(0-3.2^{\circ} \mathrm{C}\right)$ and showed no consistent trend preceding overflows. Although air temperature fluctuations appear to be an important factor associated with overflow, these results imply that overflows do not solely result from thermal fluctuations in ground temperatures driven by air temperature fluctuations. Thus, the statistical relation between icings and warming periods observed at the regional scale by Morse and Wolfe (2015) was not verified deterministically at a local scale.

\subsection{Regional context of TCWR overflows}

The two-year field study and eight-year TCWR record fit within the 24-year icing record compiled using Landsat imagery by Morse and Wolfe (2015) for the GSU. The importance of autumn rainfall on overflow activity was found both here and by Morse and Wolfe (2015). However, Morse and Wolfe (2015) found overflow activity to be inversely related to early winter air temperatures, meaning that lower temperatures in early winter were associated with higher icing activity. This contrasts with the results 
presented here that suggest warmer freezeback seasons are associated with greater overflow activity. It is interesting that the most active TCWR icing years (2005/06 and 2011/12) corresponded to the least active icing years of the GSU, and the TCWR lowicing year of 2008/09, had the highest icing activity regionally. These contrasts emphasize the importance of site- and catchment-specific factors on icings.

The relations between frequency of warming periods and lower early winter air temperatures with icing occurrence determined stochastically by Morse and Wolfe (2015) for the GSU were not observed in this study. The populations considered here and by Morse and Wolfe (2015) are not congruent. For example, their study considered an aggregate population where $80-90 \%$ of the icings were infrequent, meaning they occurred six times or less over the 24-year period, and did not necessarily reflect icings that recurred at the same location, whereas this study focused on icings that recurred at the same location. Moreover, the icings mapped by Morse and Wolfe (2015) were greater than $1800 \mathrm{~m}^{2}$ in area whereas the icings in this study were of less than $500 \mathrm{~m}^{2}$ suggesting different controlling factors may be involved.

The similarities and differences in the factors controlling icings found in this study compared to the regional assessment by Morse and Wolfe (2015) underscores the nature of the Shield threshold-mediated flow system (Spence and Woo 2006, Woo and Mielko 2008) where flow is moderated by antecedent storage conditions, which are a product of cumulative water balance over past periods, current water balance, and lake storage capacity (Woo and Mielko 2008). Therefore, the combination of contingency and catchment area at specific sites is an important factor determining icings at the local scale in the GSU. 


\subsection{Climatic context of TCWR overflows}

Analysis of the meteorological variables and the TCWR overflow record showed that the conditions during the study period were unfavourable for overflows in mid and late winter (Figure 4.17). While autumn rainfall was slightly above (2012/13) and below (2013/14) normal, the summers were drier, and early winter snowfall and mean air temperatures were lower than normal. The drier summers suggest that a portion of the autumn rainfall went to filling the summer water storage deficits (Spence and Woo 2003). This is supported by the Cameron River winter yield values, which were at their lowest (2013/14) and fourth lowest (2012/13) levels during the TCWR record period, indicating that there was less water available in the system than normal (Figure 4.17). The combination of the thinner snowpack and colder temperatures would have promoted faster freezeback. This may explain why overflows were not seen later in the winter.

The combination of meteorological conditions conducive to overflows at portages 11 and 23 (above average autumn rainfall and early winter mean air temperatures, and average snowfall) occurred five times between 1981 and 2015 and a total of six times since 1942. This observation shows that while the combination of conditions conducive for icings occurred $14 \%$ of the time in the last 35 years, it occurred five times more frequently than the preceding 39 years. The historical trends in autumn rainfall and early winter temperature show both variables gradually increasing (Figure 5.1). Autumn and early winter precipitation, and early winter mean air temperatures are projected to continue to increase over the next thirty years (SNAP 2017). If most of the projected precipitation falls as rain instead of snow, then overflow periods that extend into late winter may be expected to be more frequent in the future at sites in the GSU with 

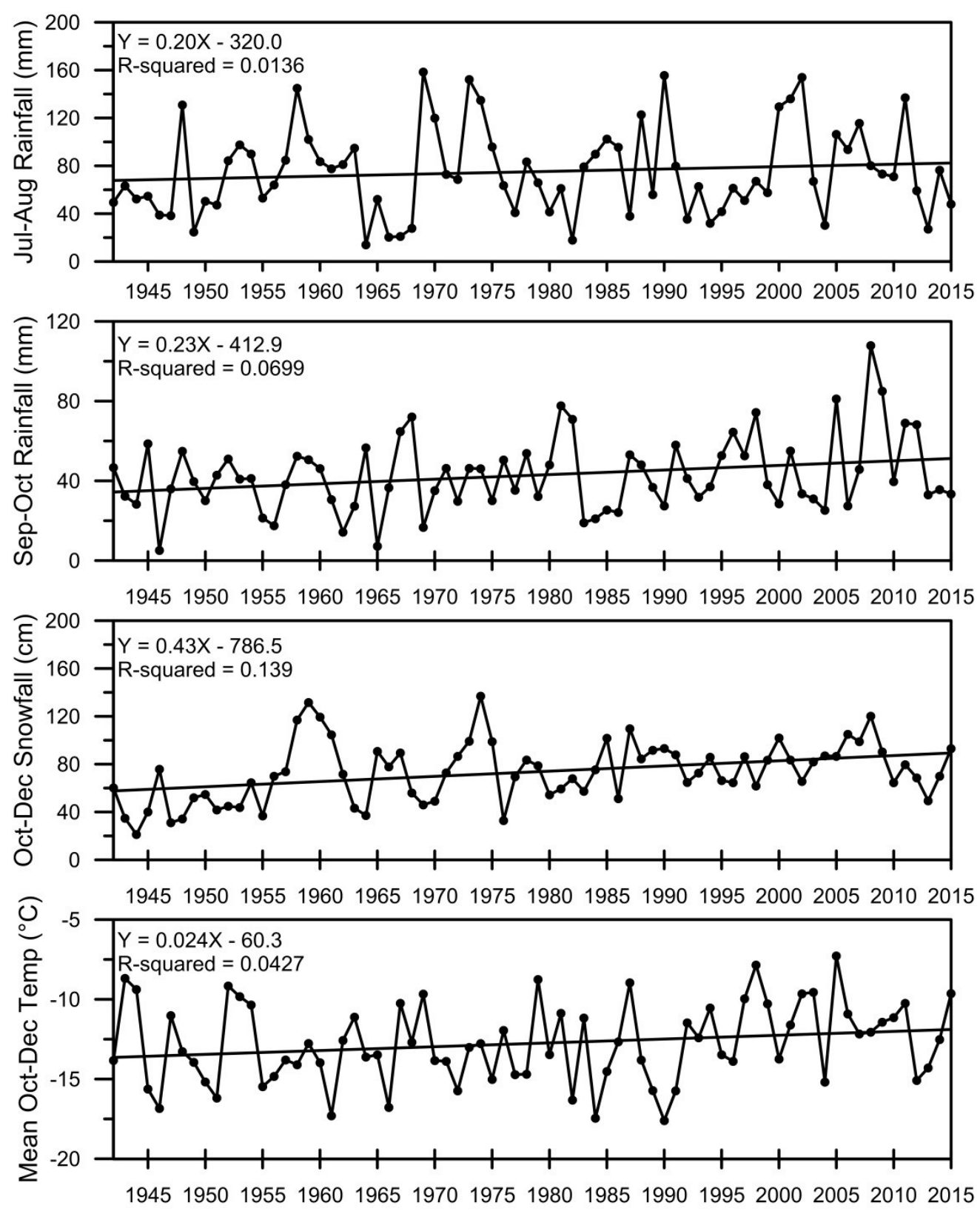

Figure 5.1 Meteorological record at Yellowknife Airport from 1942 to 2015 showing the trends in summer (Jul-Aug) and autumn (Sep-Oct) rainfall, early winter snowfall (OctDec), and early winter mean air temperature (Oct-Dec) (Environmental Canada 2016). 
conditions similar to portages 11 and 23. However, if the active-layer thickness and annual evaporation increase as a result of higher air temperatures, increased active-layer transmissivity and decreased basin storage (lake level), respectively, may counter this effect (Rouse et al. 2008, Walvoord and Kurylyk 2016).

\subsection{The overflow cycle model}

The overflow cycle is a composite model for overflows in the Great Slave Uplands derived from studies on related thermo-hydrological processes and field observations (Figure 5.2) (Kane et al. 1973, van Everdingen 1978, 1982b, Price and Fitzgibbon 1987). There are four environmental pre-requisites for the overflow cycle: (1) a source of water, (2) a hydraulically conductive medium with a shallow barrier to flow at depth, (3) seasonal frost penetration, and (4) a long winter with air temperatures below $0{ }^{\circ} \mathrm{C}$ (Carey 1973, van Everdingen 1978, 1982b, Morse and Wolfe 2017). For the system investigated in this study, the water source was P23 Lake, the peat in the fen was the conductive medium and permafrost was the barrier to flow at depth. Figure 5.3 shows a schematic of the model.

Initiation of freezeback sets the cycle in motion. Progressive freezeback in early winter of the saturated active layer restricts water movement by reducing the hydraulic transmissivity of the remaining unfrozen portion of the active layer (van Everdingen 1978, Fig. 15, p. 273, 1982b, Fig. 18, p. 260, Price and Fitzgibbon 1987). The reduction in hydraulic transmissivity and associated impoundment of lake drainage leads to increased hydraulic potential. The water under elevated hydraulic potential takes paths of least resistance, which may be around the stems of vegetation or areas with reduced frost 


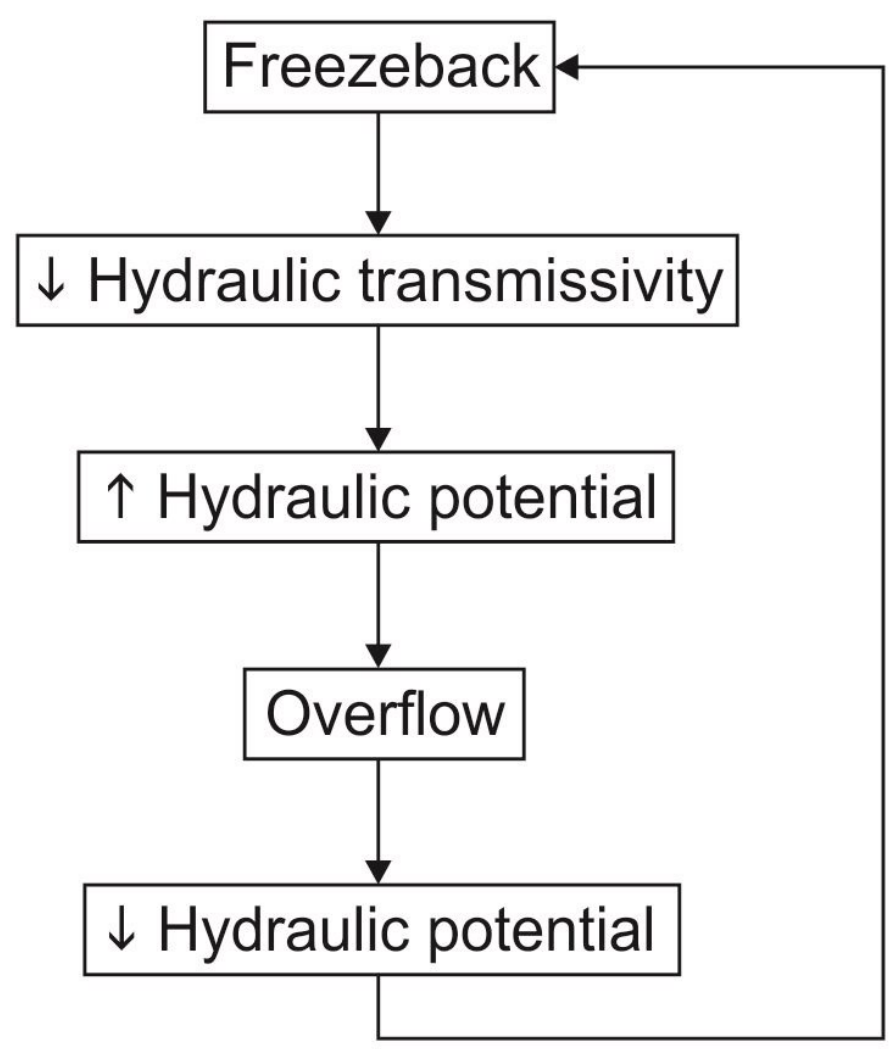

Figure 5.2 The overflow cycle. Freezeback initiates the cycle by reducing the hydraulic transmissivity of the unfrozen ground which restricts water flow and results in increased hydraulic potential. The increased hydraulic pressure causes water to overflow onto the ground or ice surface which reduces the hydraulic potential. Freezeback continues causing the cycle to repeat itself until either hydraulic pressures are insufficient to breach the ground and ice surface or freezeback cuts off water flow. 


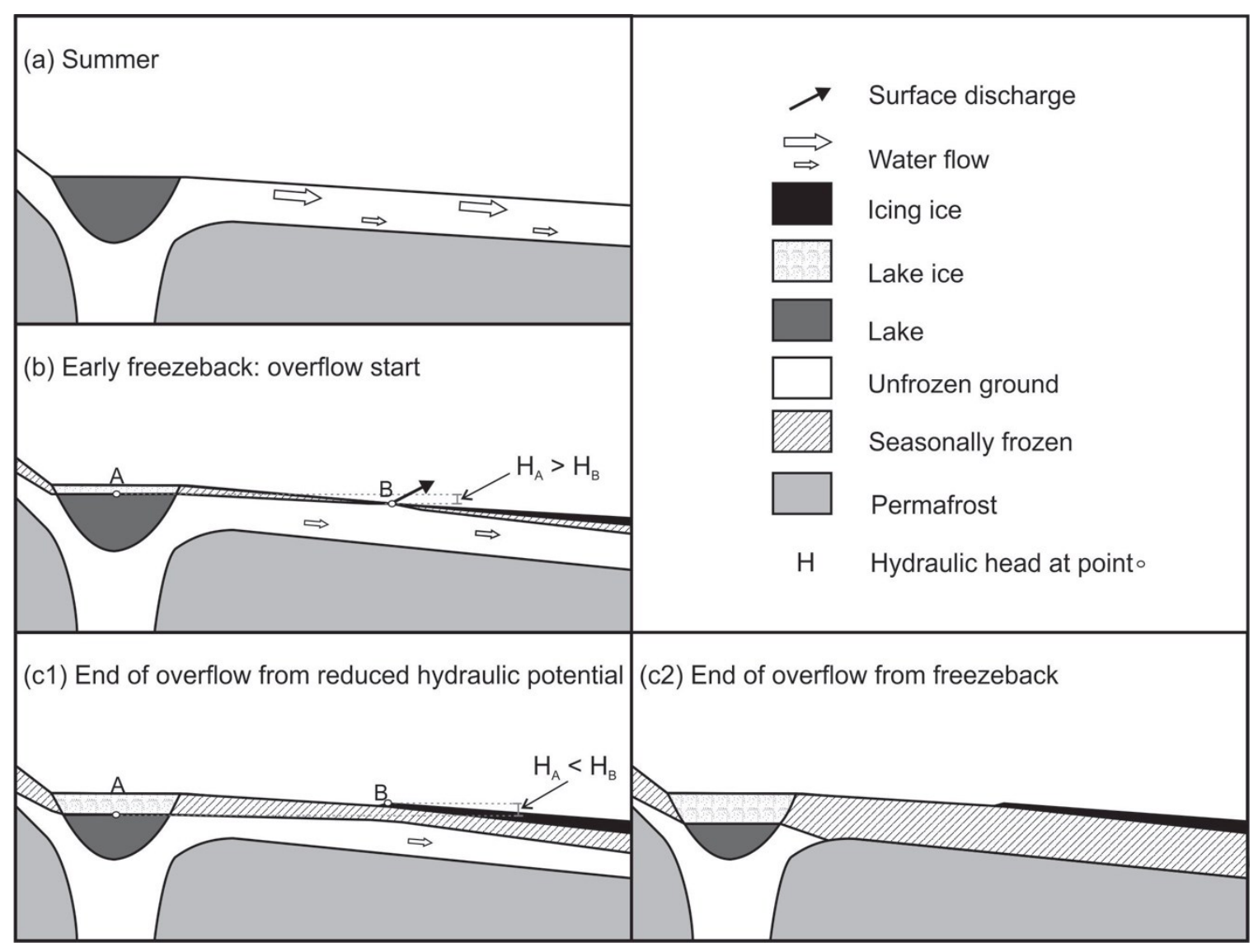

Figure 5.3 Schematic showing the thermal and hydrological conditions involved with icings in the Great Slave Uplands. (a) Summer showing flow from a lake through the active layer with most flow occurring near the surface (large arrows). (b) Early freezeback when restricted water flow through the active layer causes an increase in hydraulic potential and results in overflow. (c1) Icing formation ceases due to hydraulic head being insufficient to breach ground and ice surface downslope. (c2) Icing formation ceases due to shut off of water flow by freezeback. Not drawn to scale. 
penetration, and flows onto the surface (Figure 5.3 (b)). Overflow relieves the hydraulic pressures in the vicinity of the overflow, which ends the flow of water onto the surface.

This process is analogous to observations of stream icings where downward freezing restricts discharge by reducing the cross-sectional area for flow (Kane et al. 1973). The overflow discharge is initially relatively high and decreases as the hydraulic pressure declines. Overflow stops when the hydraulic potential drops to the ground surface. Freezeback continues, further reducing the hydraulic transmissivity and again building up hydraulic pressure. In this manner, the cycle repeats itself until freezeback is completed and cuts off the flow of water or the hydraulic potential no longer develops sufficiently to reach the ground and ice surface, as was observed in this study (Figure 5.3 $(\mathrm{c} 1, \mathrm{c} 2))$. The latter may be caused by the lake no longer receiving inflow or the increased surface elevation due to the icing thickness in the overflow area requiring a greater hydraulic pressure head for overflow. This was evident from observations made in February 2014 in the overflow area, where the hydraulic potential was a centimetre below the surface elevation of the frozen ground and therefore insufficient to breach the ice surface. A further increase in hydraulic potential of at least $11 \mathrm{~cm} \mathrm{H}_{2} \mathrm{O}$ would have been required for water to flow onto the ice surface, which was $10 \mathrm{~cm}$ thick. The episodic nature of the overflows observed in this study support a cyclical nature to the process causing formation of icings in the GSU.

\subsection{Threshold-mediated winter regime}

The thermo-hydrological process described above that leads to icing formation may have implications for the subarctic Shield threshold-mediated winter flow regime (Figure 5.4). 


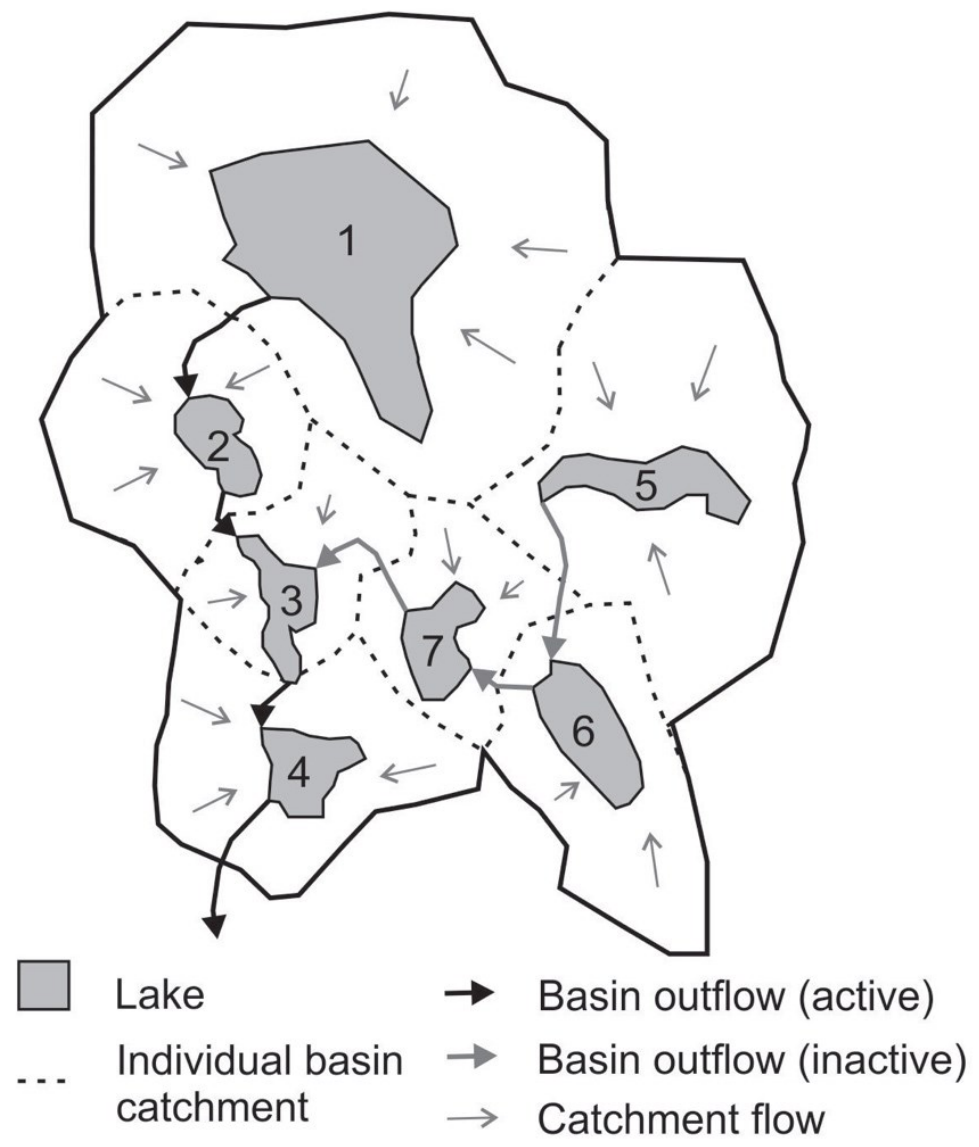

Figure 5.4 Schematic showing conceptual flow connectivity within a drainage basin in winter. Lakes are ice covered. Lakes 1-4 are connected hydrologically at the start of winter, whereas Lakes 5-7 are not. Depending on the thermal and hydrological conditions between these lakes, icings may occur at some locations but not at others. The variability in these conditions may lead to variability in the timing of flow shut off between lakes and result in disruption of the hydrological connectivity that existed at the beginning of the winter. 
Observations made in this study and by Morse and Wolfe (2015) show that the hydrological regime is active in the winter. Icings have the potential to develop downstream from any lake within a drainage basin as long as the environmental conditions are met. Autumn rainfall and antecedent storage conditions (lake levels) determine hydrological connectivity at the beginning of winter. Hence, the early winter water balance and unique site conditions will determine whether icings develop. Variability in these conditions affects the water balance and freezeback, which in turn may lead to variability in the timing of flow shut off between lakes within a drainage basin.

\subsection{Idiographic approach}

This case study highlights the nature of the thermo-hydrological process that produces icings in the Great Slave Uplands. The overflows observed in this case study varied both seasonally and annually. The most important factor affecting overflow is the hydrological status of the system, which depends on the water balance. In the surface water-dominated, threshold-meditated hydrology of the northern Shield, antecedent storage conditions and autumn rainfall are critical. The first half of freezeback is a second important controlling factor because it reduces the hydraulic transmissivity of the unfrozen portion of the active layer, which restricts water flow from lakes and generates increased hydraulic potential. This is especially critical in thick peat environments where subsurface flow is concentrated near the ground surface.

It is clear from this study, however, that although these factors are important for icing development at P23, their influence elsewhere in the GSU is not ubiquitous. The importance of catchment area and contingency on outflow generation from any one 
valley reservoir makes icings in this region difficult to predict at the regional or seasonal scale (Church 1996, Woo and Meilko 2008). This emphasizes the role of site-specific conditions on icings, as noted by others (e.g. Carey 1973, Pollard and van Everdingen 1992, Morse and Wolfe 2015). Therefore, the annual behaviour of icings should be approached on a case-by-case basis that factors in contingency. 


\section{Chapter: SUMMARY AND CONCLUSIONS}

\subsection{Summary}

The freezing seasons of the two-year study period were similar in duration and average temperature but cooler than the 1981-2010 average. Periodic overflows occurred in an open system before the end of freezeback and before winter road operations began. The source was precipitation-derived surface water found in lakes upstream of the icings. The active-layer was hydrologically connected to the source well into winter and after the observed icings had ceased forming. The observed overflow period duration and spatial extent related positively to summer and autumn rainfall during the study period.

Temperatures in the water between the icing and its source suggested intermittent flow was associated with the overflows. The eight-year TCWR overflow record suggested a combination of above average autumn rainfall and early winter mean air temperatures, and average snowfall influenced overflows at some sites while overflows at other sites did not relate to any combination of meteorological factors.

The hypotheses of this thesis were not supported by the field observations. Neither freezeback beneath the winter road nor the winter road activities were observed to cause icings during the study period. Air temperature fluctuations were not observed to be categorically related to the timing of overflow. Lastly, the observed period of overflow was not limited by the depth of freezeback.

\subsection{Conclusions}

The following four conclusions can be drawn from the examination of icings near the TCWR in the Great Slave Uplands: 
1) Icings develop from intermittent overflow of suprapermafrost groundwater. The icing source, which is precipitation-derived water stored in upstream lakes, was determined by isotopic and geochemical analyses.

2) The first half of freezeback is an important factor controlling icings in saturated peat environments. The overflows observed in the time-lapse photography ceased once freezeback in the overflow area was $18-41 \%$ completed. Overflows occurred in the fen where freezeback was prolonged.

3) Open-system freezing occurs in fens causing the build-up of hydraulic pressure and resulting in water seeping onto the ground (or ice) surface. The active layer was hydrologically connected through winter, but hydraulic pressures were insufficient to breach the combined ground and ice surface after the observed overflows had ceased.

4) Development of icings in the GSU is dependent on the water balance of the basin or lake directly upstream and site conditions. Autumn rainfall was found to be positively related to icings at some sites in this study and the TCWR record, but not others. Therefore, rainfall is an important factor driving icings but its effectiveness is moderated regionally and locally by a threshold-mediated hydrological regime where flow is a function of catchment area and antecedent conditions.

\subsection{Research implications and future work}

The results of this study have implications for infrastructure planning and operation, climate change, and future icing research. Infrastructure planners and operators in the 
Great Slave Uplands should understand the importance of approaching icings on a caseby-case basis. The significance of antecedent conditions and catchment area moderates the effect of meteorological factors making a regional-scale icing prediction model problematic, except on a statistical basis.

The implications of climate change are unclear. If autumn precipitation and early winter air temperatures continue to increase, overflow periods that extend into late winter may be expected to be more frequent at sites with conditions similar to P11 and P23 in the future. However, thicker active layers associated with warmer air temperatures and lower lake levels associated with greater evaporation, may counter this effect by increasing the hydraulic transmissivity of the unfrozen active layer and lessening the hydraulic potential, respectively.

Future research in this study area may advance the understanding of icing mechanics in peat-rich subarctic Canadian Shield valleys. Understanding the thresholdmediated winter flow regime may contribute to better understanding the factors driving periodic increases in hydraulic potential that result in icings. Examination of the influence of freezeback through hydraulically differing peat with depth on hydraulic transmissivity of the unfrozen active layer and the development of hydraulic pressure in upstream lakes may contribute to better understanding of the mechanics behind the overflow cycle. 


\section{References}

Bense, V., and Beltrami, H. 2007. Impact of horizontal groundwater flow and localized deforestation on the development of shallow temperature anomalies. Journal of Geophysical Research: Earth Surface, 112: 1-10. doi:10.1029/2006JF000703.

Brown, R.J.E. 1960. The distribution of permafrost and its relation to air temperature in Canada and the U.S.S.R. Arctic, 13: 163-177. doi:10.14430/arctic3697.

Brown, R.J.E. 1973. Influence of climatic and terrain factors on ground temperatures at three locations in the permafrost region of Canada. In Proceedings of the Second International Conference on Permafrost, North American Contribution, National Academy Press, Washingon, D.C., pp. 27-34.

Burn, C.R. 1995. The hydrological regime of Mackenzie River and connection of "noclosure" lakes to distributary channels in the Mackenzie Delta, Northwest Territories. Canadian Journal of Earth Sciences, 32: 926-937.

Burn, C.R. 1998. The response (1958-1997) of permafrost and near-surface ground temperatures to forest fire, Takhini River valley, southern Yukon Territory. Canadian Journal of Earth Sciences, 35: 184-199. doi:10.1139/e97-105.

Burn, C.R. 2004. Thermal regime of cryosols. In Cryosols: Permafrost-affected Soils. Edited by J.M. Kimble. Springer, Berlin, Germany, pp. 391-413.

Burn, C.R. 2012. Permafrost distribution and stability. In Changing cold Environments: A Canadian Perspective. Edited by H. French and O. Slaymaker. John Wiley \& Sons, Ltd., Chichester, U.K., pp. 126-146. doi:10.1002/9781119950172.ch7 
Carey, K.L. 1973. Icings developed from surface water and ground water. Cold Regions Research and Engineering laboratory Monograph III-D3, U.S. Army Corps of Engineers, Hanover, NH.

Carey, S.K., and Woo, M. 2005. Freezing of subarctic hillslopes, Wolf Creek Basin, Yukon, Canada. Arctic, Antarctic, and Alpine Research, 37: 1-10.

Chekotillo, A.M. 1949. Icings and countermeasures. In Investigation of Airfield Drainage - Arctic and Subarctic Regions, Part II Translations of selected topics. Prepared by M. Pilch. Minneapolis, University of Minnesota, St. Anthony Falls Hydraulic Laboratory, for U.S. Army Corps of Engineers, St. Paul District, pp. 100-148.

Church, M. 1996. Space, time and the mountain - how do we order what we see? In The Scientific Nature of Geomorphology: Proceedings of the 27th Binghamton Symposium in Geomorphology. Edited by B.L. Rhoads and C.E. Thorn. John Wiley \& Sons Ltd., Chichester, U.K., pp. 147-170.

Clark, I.D., and Lauriol, B. 1997. Aufeis of the Firth River Basin, Northern Yukon, Canada: Insights into permafrost hydrogeology and karst. Arctic and Alpine Research, 29: 240-252. doi:10.2307/1552053.

Craig, H. 1961. Isotopic variations in meteoric waters. Science, 133: 1702-1703.

Dansgaard, W. 1964. Stable isotopes in precipitation. Tellus, 16: 436-468. doi:10.3402/tellusa.v16i4.8993.

Dyke, A.S., Moore, A., and Robertson, L. 2003. Deglaciation of North America. Geological Survey of Canada, Open File 1574, Ottawa, ON. doi:10.4095/214399. 
Eager, W.L., and Pryor, W.T. 1945. Ice formation on the Alaska Highway. Public Roads, 24: 55-74, 82 .

EBA 2002. Tibbitt to Contwoyto Winter Road ecological land classification. Tetra Tech EBA Engineering Consultants Ltd., Suite $1000-10^{\text {th }}$ Floor, 885 Dunsmuir Street, Vancouver, BC.

Ecosystem Classification Group. 2008. Ecological Regions of the Northwest Territories Taiga Shield. Department of Environment and Natural Resources, Government of the Northwest Territories, Yellowknife, NT. viii + 146 pp. + insert map.

Ecosystem Classification Group. 2012. Ecological Regions of the Northwest Territories Southern Arctic. Department of Environment and Natural Resources, Government of the Northwest Territories, Yellowknife, NT. $x+170$ pp. + insert map.

Environment Canada. 2016. Historical Climate Data [online]: Available from http://climate.weather.gc.ca/.

Environment Canada. 2017. Historical Hydrometric Data [online]: Available from http://wateroffice.ec.gc.ca/.

van Everdingen, R.O. 1978. Frost mounds at Bear Rock, near Fort Norman, Northwest Territories, 1975-1976. Canadian Journal of Earth Sciences, 15: 263-276.

van Everdingen, R.O. 1982a. Management of groundwater discharge for the soluton of icing problems in the Yukon. In The Roger J.E. Brown Memorial Volume: Proceedings of the Fourth Canadian Permafrost Conference. Edited by H.M. French. National Research Council of Canada, Ottawa, ON, pp. 212-226. 
van Everdingen, R.O. 1982b. Frost blisters of the Bear Rock spring area near Fort Norman, N.W.T. Arctic, 35: 243-265.

van Everdingen, R.O., and Allen, H.D. 1983. Ground movements and dendrogeomorphology in a small icing area on the Alaska Highway, Yukon, Canada. In Proceedings of the Fourth International Conference on Permafrost, National Academy of Sciences, Washington, D.C., pp. 1292-1297.

van Everdingen, R.O., and Banner, J.A. 1979. Use of long-term automatic time-lapse photography to measure the growth of frost blisters. Canadian Journal of Earth Sciences, 16: 1632-1635.

Farouki, O.T. 1981. Thermal properties of soils. Cold Regions Research and Engineering Laboratory, Monograph 81-1, U.S. Army Corps of Engineers, Hanover, NH.

French, H. 1996. The Periglacial Environment. 2nd edition. Addison Wesley Longman Ltd., Essex, England.

Fritz, P., Drimmie, R.J., Frape, S.K., and O’Shea, K. 1987. The isotopic composition of precipitation and groundwater in Canada. In Isotope Techniques in Water Resources Development, Proceedings of an International Symposium on the Use of Isotope Techniques in Water Resources Development, International Atomic Energy Agency, Vienna, Austria, pp. 539-550.

Gaanderse, A.J.R. 2015. Geomorphic origin of a lithalsa in the Great Slave Lowlands, Northwest Territories, Canada. M.Sc. thesis, Department of Geography, Carleton University, Ottawa, ON. 
Geoscientific. 2016. Geo Scientific Ltd. Sampling Instrumentation [online]. Available from http://www.geoscientific.com/sampling/ [accessed 9 August 2016].

Gibson, J.J., and Reid, R. 2010. Stable isotope fingerprint of open-water evaporation losses and effective drainage area fluctuations in a subarctic shield watershed. Journal of Hydrology, 381: 142-150. doi:10.1016/j.jhydrol.2009.11.036.

Gibson, J.J., Edwards, T.W.D., Bursey, G.G., and Prowse, T.D. 1993. Estimating evaporation using stable isotopes: quantitative results and sensitivity analysis for two catchments in Northern Canada. Nordic Hydrology, 24: 79-94.

Gibson, J.J., Reid, R., and Spence, C. 1998. A six-year isotopic record of lake evaporation at a mine site in the Canadian subarctic: results and validation. Hydrological Processes, 12: 1779-1792. doi:10.1002/(SICI)10991085(199808/09)12:10/11<1779::AID-HYP694>3.0.CO;2-7.

GNWT. 2011. Fire history shapefile: IBLFMD_FIRE_HISTORY.shp. Forest Management Division, Environment and Natural Resources, Government of the Northwest Territories, Hay River, NT.

Gold, L. 1963. Influence of the snow cover on the average annual ground temperature at Ottawa, Canada. International Association of Scientific Hydrology Publication, 61: $82-91$.

Goodrich, L.E. 1982. The influence of snow cover on the ground thermal regime. Canadian Geotechnical Journal, 19: 421-432. doi:10.1139/t82-047.

Hallet, B. 1978. Solute redistribution in freezing ground. In Proceedings of the Third 
International Conference on Permafrost, National Research Council of Canada, Ottawa, ON, Vol. 1, pp. 85-91.

Harden, D., Barnes, P., and Reimnitz, E. 1977. Distribution and character of naleds in northeastern Alaska. Arctic, 30: 28-40. doi:10.1017/CBO9781107415324.004.

Heginbottom, J.A., Dubreuil, M.A., and Harker, P.A. 1995. Canada-Permafrost. In National Atlas of Canada, 5th edition. Natural Resources Canada, Ottawa, ON, MCR4177.

Hinkel, K.M., and Outcalt, S.I. 1994. Identification of heat-transfer processes during soil cooling, freezing, and thaw in central Alaska. Permafrost and Periglacial Processes, 5: 217-235. doi:10.1002/ppp.3430050403.

Hinkel, K.M., Peterson, K.M., Eisner, W.R., Nelson, F.E., Turner, K.M., Miller, L.L., and Outcalt, S.I. 1996. Formation of injection frost mounds over winter 1995-1996 at Barrow, Alaska. Polar Geography, 20: 235-248. doi:10.1080/10889379609377605.

Hu, X., and Pollard, W.H. 1997a. Ground icing formation: experimental and statistical analyses of the overflow process. Permafrost and Periglacial Processes, 8: 217-235. doi:10.1002/(SICI)1099-1530(199732)8:2<217::AID-PPP251>3.3.CO;2-T.

Hu, X., and Pollard, W.H. 1997b. The hydrologic analysis and modelling of river icing growth, North Fork Pass, Yukon Territory, Canada. Permafrost and Periglacial Processes, 8: 279-294. doi:10.1002/(SICI)1099-1530(199709)8:3<279::AIDPPP260>3.3.CO;2-Z. 
Joint Venture. 2016. Facts - Tibbitt to Contwoyto winter road Joint Venture [online]. Available from http://www.jvtcwinterroad.ca/facts.html [accessed 15 March 2016].

Kane, D.L. 1981. Physical mechanics of aufeis growth. Canadian Journal of Civil Engineering, 8: 186-195. doi:10.1139/181-026.

Kane, D.L., and Carlson, R.F. 1977. Analysis of stream aufeis growth and climatic conditions. In Proceedings of the Third National Hydrotechnical Conference. Canadian Scoiety for Civil Engineering, Quebec, QC, pp. 656-670.

Kane, D.L., and Slaughter, C.W. 1973. Seasonal regime and hydrological significance of stream icings in central Alaska. In Proceedings of The Role of Snow and Ice in Hydrology, IAHS Publication 107, International Association of Hydrological Sciences, Wallingford, U.K., pp. 528-540.

Kane, D.L., Carlson, R.F., and Bowers, C.E. 1973. Groundwater pore pressures adjacent to subarctic streams. In Proceedings of the Second International Conference on Permafrost, North American Contribution, National Academy of Sciences, Washington, D.C., pp. 453-458. doi:10.1017/CBO9781107415324.004.

Kane, D.L., Hinkel, K.M., Goering, D.J., Hinzman, L.D., and Outcalt, S.I. 2001. Nonconductive heat transfer associated with frozen soils. Global and Planetary Change, 29: $275-292$.

Kane, D.L., Yoshikawa, K., and McNamara, J.P. 2013. Regional groundwater flow in an area mapped as continuous permafrost, NE Alaska (USA). Hydrogeology Journal, 21: 41-52. doi:10.1007/s10040-012-0937-0. 
Karunaratne, K.C. 2011. A Field Examination of Climate-Permafrost Relations in Continuous and Discontinuous Permafrost of the Slave Geological Province. Ph.D. thesis, Department of Earth Sciences, Carleton University, Ottawa, ON.

Karunaratne, K.C., Kokelj, S. V., and Burn, C.R. 2008. Near-surface permafrost conditions near Yellowknife, Northwest Territories, Canada. In Proceedings of the Ninth International Conference on Permafrost. Edited by D.L. Kane and K.M. Hinkel. Institute of Northern Engineering, University of Alaska Fairbanks, Fairbanks, Alaska, Vol.1, pp. 907-912.

Kerr, D.E., Wolfe, S.A., and Dredge, L.A. 1997. Surficial geology of the Contwoyto Lake map area (north half), District of Mackenzie, Northwest Territories. In Current research 1997-C. Geological Survey of Canada, Ottawa, ON, pp. 51-59.

Kokelj, S.A. 2003. Hydrologic overview of the North and South Slave regions. Water Resources Division, Indian and Northern Affairs Canada, Yellowknife, NT. Available from https://www.aadncaandc.gc.ca/eng/1100100024400/1100100024552b [accessed 15 March 2017].

Kokelj, S. V., Spence, C., and Kokelj, S.A. 2012. A Report to the Giant Mine Team, Changing hydrological regimes - Baker Creek: Results, implications and next steps [online]: Available from http://sdw.enr.gov.nt.ca/nwtdp_upload/GIANT_report_April\%202012_.pdf [accesssed 16 March 2017].

Kurylyk, B.L., and Hayashi, M. 2016. Improved Stefan equation correction factors to accommodate sensible heat storage during soil freezing or thawing. Permafrost and 
Periglacial Processes, 203: 189-203. doi:10.1002/ppp.1865.

Kurylyk, B.L., McKenzie, J.M., MacQuarrie, K.T.B., and Voss, C.I. 2014. Analytical solutions for benchmarking cold regions subsurface water flow and energy transport models: One-dimensional soil thaw with conduction and advection. Advances in Water Resources, 70: 172-184. doi:10.1016/j.advwatres.2014.05.005.

Lauriol, B., Cinq Mars, J., and Clark, I.D. 1991. Localisation, genèse et fonte de quelques naleds du Nord du Yukon (Canada). Permafrost and Periglacial Processes, 2: 225236.

Luthin, J.N., and Guymon, G.L. 1974. Soil moisture - vegetation - temperature relationship in Central Alaska. Journal of Hydrology, 23: 233-246.

MacFarlane, I.C., and Allen, C.M. 1964. An examination of some index test procedures for peat: a progress report. In Proceedings of the Ninth Muskeg Resource Conference, Techical Memorandum 81, National Research Council, Ottawa, ON, pp. 171-183. Available from http://nparc.cisti-icist.nrccnrc.gc.ca/eng/view/accepted/?id=71e2e5cc-e708-4e82-8734-3654d1 dada0a [accessed 15 March 2017].

Mackay, J.R. 1977. Pulsating pingos, Tuktoyaktuk Peninsula, N.W.T. Canadian Journal of Earth Sciences, 14: 209-222. doi10.1139/e77-023.

Mackay, J.R. 1983. Downward water movement into frozen ground, western arctic coast, Canada. Canadian Journal of Earth Sciences, 20: 120-134. doi:10.1139/e83-012.

Mark, D.M., and Church, M. 1977. On the misuse of regression in earth science. 
Mathematical Geology, 9: 63-75. doi:10.1007/BF02312496.

Michel, F.A. 1986. Isotope geochemistry of frost-blister ice, North Fork Pass, Yukon. Canadian Journal of Earth Sciences, 23: 543-549.

Michel, F.A. 2011. Isotope characterisation of ground ice in northern Canada. Permafrost and Periglacial Processes, 22: 3-12. doi:10.1002/ppp.721.

Moorman, B.J., Michel, F.A., and Drimmie, R.J. 1996. Isotopic variability in arctic precipitation as a climatic indicator. Geoscience Canada, 23: 189-194.

Morse, P.D., and Burn, C.R. 2014. Perennial frost blisters of the outer Mackenzie Delta, western Arctic coast, Canada. Earth Surface Processes and Landforms, 39: 200-213. doi:10.1002/esp.3439.

Morse, P.D., and Wolfe, S.A. 2015. Geological and meteorological controls on icings (aufeis) dynamics (1985 to 2014) in subarctic Canada. Journal of Geophysical Research : Earth Surface, 120: 1670-1686. doi:10.1002/2015JF003534.

Morse, P.D., and Wolfe, S.A. 2017. Long-term river icing dynamics in discontinuous permafrost, subarctic Canadian Shield. Permafrost and Periglacial Processes, 29: (in press). doi:10.1002/ppp.1907.

Morse, P.D., Wolfe, S.A., Kokelj, S. V, and Gaanderse, A.J.R. 2015. The occurrence and thermal disequilibrium state of permafrost in forest ecotopes of the Great Slave region, Northwest Territories, Canada. Permafrost and Periglacial Processes, 27: 145-162. doi:10.1002/ppp.1858.

Muller, S.W. 1945. Permafrost or permanently frozen ground and related engineering 
problems. Military Intelligence Division Office, Chief of Engineers, U.S. Army, Washington, D.C.

Nakano, Y., and Brown, J. 1972. Mathematical modeling and validation of the thermal regimes in tundra soils, Barrow, Alaska. Arctic and Alpine Research, 4: 19-38.

National Wetlands Working Group. 1997. The Canadian wetland classification system: $2^{\text {nd }}$ Edition. Edited by B.G. Warner and C.D.A. Rubec, Wetlands Research Centre, University of Waterloo, Waterloo, ON. doi:10.1002/15213773(20010316)40:6<9823::AID-ANIE9823>3.3.CO;2-C.

Nelson, F.E., Outcalt, S.I., Goodwin, C.W., and Hinkel, K.M. 1985. Diurnal thermal regime in a peat-covered palsa, Toolik Lake, Alaska. Arctic, 38: 310-315. doi: $10.2307 / 40511003$.

Nowicki, T., Crawford, B., Dyck, D., Carlson, J., McElroy, R., Oshust, P., and Helmstaedt, H. 2004. The geology of kimberlite pipes of the Ekati property, Northwest Territories, Canada. Lithos, 76: 1-27. doi:10.1016/j.lithos.2004.03.020.

NRC. 1988. Glossary of permafrost and related ground-ice terms. National Research Council of Canada, Ottawa, ON. Available from http://globalcryospherewatch.org/reference/glossary_docs/permafrost_and_ground_t erms_canada.pdf [accessed 9 May 2016].

Nuna Logistics. 2017. Tibbitt to Contwoyto Winter Road Joint Venture Ltd. | Nuna Logistics [online]. Available from http://nunalogistics.com/clients/winter_road.html [accessed 1 March 2017]. 
Olthof, I., Kerr, D.E., Wolfe, S.A., and Eagles, S. 2014. Predictive surficial materials and surficial geology from LANDSAT-7, Upper Carp Lake, NTS 85-P, Northwest Territories. Geological Survey of Canada, Open File 7601, Ottawa, ON. doi:10.4095/293970.

Osterkamp, T.E., and Romanovsky, V.E. 1997. Freezing of the active layer on the Coastal Plain of the Alaskan Arctic. Permafrost and Periglacial Processes, 8: 23-44. doi:10.1002/(SICI)1099-1530(199701)8:1<23::AID-PPP239>3.0.CO;2-2.

Outcalt, S.I., and Hinkel, K.M. 1996. The response of near-surface permafrost to seasonal regime transitions in tundra terrain. Arctic and Alpine Research, 28: 274-283.

Padgham, W.A., and Fyson, W.K. 1992. The Slave Province: a distinct Archean craton. Canadian Journal of Earth Sciences, 29: 2072-2086. doi:10.1139/e92-165.

Palmer, M.J., Burn, C.R., and Kokelj, S.V. 2012. Factors influencing permafrost temperatures across treeline in the uplands east of the Mackenzie Delta, 2004-2010. Canadian Journal of Earth Sciences, 49: 877-894.

Phillips, M.R., Burn, C.R., Wolfe, S.A., Morse, P.D., Gaanderse, A.J., O’Neill, H.B., Shugar, D.H., and Gruber, S. 2015. Improving water content description of ice-rich permafrost soils. In Proceedings of the $68^{\text {th }}$ Canadian Geotechnical Conference and 7th Canadian Permafrost Conference. Quebec, QC, Paper 372, Canadian Geotechnical Society, Richmond, BC.

Pollard, W.H., and van Everdingen, R.O. 1992. Formation of seasonal ice bodies. In Periglacial Geomorphology, Proceedings of the 22nd Annual Binghamton 
Symposium in Geomorphology. Edited by J.C. Dixon and A.D. Abrahams. John Wiley \& Sons, Chichester, U.K., pp. 281-304.

Pollard, W.H., and French, H.M. 1984. The groundwater hydraulics of seasonal frost mounds, North Fork Pass, Yukon Territory. Canadian Journal of Earth Sciences, 21: 1073-1081. doi:10.1139/e84-112.

Price, J.S. 1983. The effect of hydrology on ground freezing in a watershed with organic terrain. In Proceedings of the Fourth International Conference on Permafrost, National Academy Press, Washingon, D.C., pp. 1009-1014.

Price, J.S., and FitzGibbon, J.E. 1982. Winter hydrology of a forested drainage basin. In Proceedings of the Canadian Hydrology Symposium. Fredericton, N.B., pp. 347359.

Price, J.S., and FitzGibbon, J.E. 1987. Groundwater storage - streamflow relations during winter in a subarctic wetland, Saskatchewan. Canadian Journal of Earth Sciences, 24: 2074-2081.

Quinton, W.L., Hayashi, M., and Carey, S.K. 2008. Peat hydraulic conductivity in cold regions and its relation to pore size and geometry. Hydrological Processes, 22: 2829-2837. doi:10.1002/hyp.7027.

Romanovsky, V.E., and Osterkamp, T.E. 1995. Interannual variations of the thermal regime of the active layer and near-surface permafrost in northern Alaska. Permafrost and Periglacial Processes, 6: 313-335. doi:10.1002/ppp.3430060404.

Romanovsky, V.E., and Osterkamp, T.E. 2000. Effects of unfrozen water on heat and 
mass transport processes in the active layer and permafrost. Permafrost and Periglacial Processes, 11: 219-239. doi:10.1002/10991530(200007/09)11:3<219::AID-PPP352>3.0.CO;2-7.

Rouse, W.R., Binyamin, J., Blanken, P.D., Bussières, N., Duguay, C.R., Oswald, C.J., Schertzer, W.M., and Spence, C. 2008. The influence of lakes on the regional energy and water balance of the central Mackenzie River Basin. In Cold Region Atmospheric and Hydrologic Studies. Edited by M-k. Woo. Springer-Verlag, Berlin, Germany, pp. 309-325.

Saarelainen, S.M.I. 2008. Arctic road research program: Experiences and implementation. In Proceedings of the Ninth International Conference on Permafrost. Edited by D.L. Kane and K.M. Hinkel. Institute of Northern Engineering, University of Alaska Fairbanks, Fairbanks, Alaska, Vol. 2, pp. $1543-$ 1547.

Slaughter, C.W. 1982. Occurrence and recurrence of aufeis in an upland taiga catchment. In The Roger J.E. Brown Memorial Volume: Proceedings of the Fourth Canadian Permafrost Conference. Edited by H.M. French. National Research Council of Canada, Ottawa, ON, pp. 182-188.

Sloan, C.E., Zenone, C., and Mayo, L.R. 1976. Icings along the Trans-Alaska pipeline route. U.S. Department of the Interior, Geological Survey Professional Paper 979, Washington, D.C.

Smith, M.W. 1975. Microclimatic influences on ground temperatures and permafrost distribution, Mackenzie Delta, Northwest Territories. Canadian Journal of Earth 
Sciences, 12: 1421-1438. doi:10.1139/e75-129.

Smith, M.W., and Riseborough, D.W. 2002. Climate and the limits of permafrost: a zonal analysis. Permafrost and Periglacial Processes, 13: 1-15. doi:10.1002/ppp.410.

SNAP. 2017. Scenarios Network for Alaska and Arctic Planning [online]. Available from https://www.snap.uaf.edu/sites/all/modules/snap_community_charts/charts.php [accessed 31 January 2017].

Spence, C., and Woo, M-k. 2003. Hydrology of subarctic Canadian Shield: soil-filled valleys. Journal of Hydrology, 279: 151-166.

Spence, C., and Woo, M-k. 2006. Hydrology of subarctic Canadian Shield: heterogeneous headwater basins. Journal of Hydrology, 317: 138-154. doi:10.1016/j.jhydrol.2005.05.014.

Spence, C., and Woo, M-k. 2008. Hydrology of the northwestern subarctic Canadian Shield. In Cold Region Atmospheric and Hydrologic Studies. Edited by M-k. Woo. Springer-Verlag, Berlin, Germany, pp. 235-256.

Spence, C., Kokelj, S. V., and Ehsanzadeh, E. 2011. Precipitation trends contribute to streamflow regime shifts in northern Canada. In Cold Region Hydrology in a Changing Climate. Edited by D. Yang, P. Marsh, and A. Gelfan, IAHS publication 346, International Association of Hydrological Sciences, Wallingford, U.K., pp. 38.

Spence, C., Kokelj, S.A., Kokelj, S. V, and Hedstrom, N. 2014. The process of winter streamflow generation in a subarctic Precambrian Shield catchment. Hydrological 
Processes, 28: 4179-4190. doi:10.1002/hyp.10119.

Stevens, C.W., Kerr, D.E., Wolfe, S.A., and Eagles, S. 2013. Predictive surficial materials and surficial geology derived from LANDSAT 7, Hearne Lake, NTS 85I, Northwest Territories. Geological Survey of Canada, Open File 7233, Ottawa, ON. doi:10.4095/292394.

Stotler, R.L. 2008. Evolution of Canadian Shield groundwaters and gases: Influence of deep permafrost. Ph.D. thesis, Department of Earth Sciences, University of Waterloo, Waterloo, ON.

Sturm, M., Holmgren, J., König, M., and Morris, K. 1997. The thermal conductivity of seasonal snow. Journal of Glaciology, 43: 26-41.

Thomson, S. 1966. Icings on the Alaska Highway. In Proceedings of the International Conference on Permafrost, National Academy of Sciences, Washington, D.C., pp. 526-529.

Thorne, G.A. 1992. Soil moisture storage and groundwater flux in small Precambrian Shield catchments. In Proceedings of the 9th International Northern Research Basins Symposium and Workshop. Edited by T.D. Prowse, C.S.L. Ommanney, and K.E. Ulmer, National Hydrology Research Institute, Saskatoon, SK, pp. 555-574.

Veillette, J.J., and Thomas, R.D. 1979. Icings and seepage in frozen glaciofluvial deposits, District of Keewatin, N.W.T. Canadian Geotechnical Journal, 16: 789-798.

Vinson, T.S., and Lofgren, D. 2003. Denali Park access road icing problems and mitigation options. In Proceedings of the Eighth International Conference on 
Permafrost. Edited by M. Phillips, S.M. Springman, and L.U. Arenson. A.A.

Balkema, Lisse, The Netherlands, Vol. 2, pp. 1189-1194.

Walvoord, M.A., and Kurylyk, B.L. 2016. Hydrologic impacts of thawing permafrost - a review. Vadose Zone Journal, 15: 1-20. doi:10.2136/vzj2016.01.0010.

Williams, P.J., and Smith, M.W. 1989. The Frozen Earth: Fundamentals of Geocryology. Cambridge University Press, England.

Wolfe, S.A., Hoeve, T.E., and Smith, S. 1998. Part II: Living with frozen ground, In Living with Frozen Ground, A field guide to permafrost in Yellowknife, Northwest Territories. Geological Survey of Canada, Miscellaneous Report 64, Ottawa, ON, pp. 14-31.

Wolfe, S.A., Duchesne, C., Gaanderse, A.J., Houben, A.J., D’Onofrio, R.E., Kokelj, S. V., and Stevens, C.W. 2011. Report on 2010-11 permafrost investigations in the Yellowknife area, Northwest Territories. Geological Survey of Canada, Open File 6983, Ottawa, ON. doi:10.4095/289596.

Woo, M-k. 2012. Permafrost Hydrology. Springer-Verlag, Berlin, Germany. doi:10.1007/978-3-642-23462-0.

Woo, M-k., and Mielko, C. 2006. Snowmelt runoff processes in a headwater lake and its catchment, subarctic Canadian Shield. Hydrological Processes, 20:987-1000. doi:10.1002/hyp.6117.

Woo, M-k., and Mielko, C. 2007. An integrated framework of lake-stream connectivity for a semi-arid, subarctic environment. Hydrological Processes, 21: 2668-2674. 
doi:10.1002/hyp.6789.

Woo, M-k., and Mielko, C. 2008. Flow connectivity of a lake-stream system in a semiarid Precambrian Shield environment. In Cold Region Atmospheric and Hydrologic Studies. Edited by M-k. Woo. Springer-Verlag, Berlin, Germany, pp. 221-233.

Yoshikawa, K., Petrone, K., Hinzman, L.D., and Bolton, W.R. 1999. Aufeis development and stream baseflow hydrology in the discontinuous permafrost region, Caribou Poker Creeks Research Watershed, Interior Alaska. In Programs and Abstracts, 50th Arctic Science Conference, American Association for the Advancement of Science, Arctic Dvision, Fairbanks, AK, pp. 202-203.

Yoshikawa, K., Hinzman, L.D., and Kane, D.L. 2007. Spring and aufeis (icing) hydrology in Brooks Range, Alaska. Journal of Geophysical Research, 112: 1-14. doi:10.1029/2006JG000294.

Zhang, T. 2005. Influence of the seasonal snow cover on the ground thermal regime: An overview. Reviews of Geophysics, 43: 1-23. doi:10.1029/2004RG000157. 